\title{
ACESSO À EDUCAÇÃO BÁSICA E SUA UNIVERSALIZAÇÃO: MISSÃO AINDA A SER CUMPRIDA
}

\author{
Armando Amorim Simões ${ }^{\text {I }}$
}

http://dx.doi.org/10.24109/9786581041076.ceppe.v2a1

\section{RESUMO}

Com base na revisão do debate acadêmico sobre o acesso à educação básica no Brasil, este trabalho analisa as curvas de acesso, um indicador gráfico que evidencia os aspectos da integralidade e universalidade do acesso escolar entre os jovens de diferentes grupos sociais. Até que ponto chegam, em média, os jovens na trajetória escolar? Em que etapas da trajetória escolar os alunos se evadem? Que desigualdades de acesso existem entre diferentes grupos da população? Que padrões podem ser identificados no acesso escolar em diferentes regiões e estados? Houve evolução no acesso à educação básica no Brasil ao longo do período 2002-2017? Quais estados apresentam melhor desempenho quanto ao acesso à educação básica? Descortinar o fenômeno do acesso escolar e identificar padrões na sua evolução ao longo do tempo é tarefa central para entender que a universalização do acesso à educação básica é, ainda, uma missão a ser cumprida no Brasil.

Palavras-chave: acesso à escola; educação básica; indicadores; Plano Nacional de Educação.

\footnotetext{
I Armando Amorim Simões é PhD em educação pela Universidade de Sussex, no Reino Unido. É da carreira de Especialista em Políticas Públicas e Gestão Governamental em exercício no Instituto Nacional de Estudos e Pesquisas Educacionais Anísio Teixeira (Inep), atuando na Diretoria de Estudos Educacionais (Dired).
} 


\section{INTRODUÇÃO}

O acesso escolar à educação básica no Brasil é tema recorrente no debate educacional face à contradição existente entre a alta taxa de cobertura escolar na idade de 6 a 14 anos, alcançada pelo país já a partir do final dos anos 1990, e a baixa taxa de concluintes na idade recomendada somada ao grande número de jovens no Brasil que se evadem sem completar essa etapa de ensino. Em particular, os Planos Nacionais de Educação (PNE) trataram de estabelecer metas de universalização que alcançassem a população em idade escolar obrigatória ${ }^{1}$. Ainda, a equidade na política educacional aparece como diretriz transversal no último PNE (2014-2014) e de forma objetiva em metas que tratam da necessidade de igualar a escolarização de jovens e adultos de diferentes estratos de renda, regiões e grupos de raça/cor como parte do direito universal à educação. Por outro lado, a análise do acesso por meio dos indicadores tradicionais, como a taxa de atendimento e a taxa líquida de matrícula, não permite descortinar por completo o fenômeno do acesso escolar no Brasil. As limitações desses indicadores motivaram a construção de um novo indicador (a curva de $a c e s s o^{2}$ ) que permite identificar as trajetórias do acesso escolar para diferentes grupos da população a partir da definição do acesso à educação básica em termos de dois atributos que devem ser satisfeitos simultaneamente - a integralidade e a universalidade ${ }^{3}$.

Com base na redefinição do conceito de acesso, usando dados da Pesquisa Nacional por Amostra de Domicílios (Pnad) e Pnad Contínua (PnadC), este trabalho analisa o acesso escolar a partir das curvas de acesso para o Brasil, grandes regiões, diferentes grupos sociais e unidades da Federação, descrevendo até que ano escolar chegam os jovens brasileiros. Outras questões de interesse que se desdobram das análises feitas são: até que ponto chega, em média, o jovem na trajetória escolar? Em que etapas da trajetória escolar os alunos do quintil mais pobre se evadem? Há desigualdades de acesso entre diferentes grupos da população? Que padrões e diferenças podem ser identificados no acesso escolar entre as regiões e estados do Brasil? Houve evolução no acesso à educação básica no Brasil ao longo do período 2002-2017? Que estados apresentam melhor desempenho quanto ao acesso à educação básica? Compreender o fenômeno do acesso escolar e seus desafios exige mudanças na forma como o conceito de acesso é definido e na sua análise, identificando as lacunas e exclusões que comprometem a sua universalização.

\footnotetext{
1 O atual PNE (2014-2024) fixou nas Metas 1, 2 e 3 os objetivos de universalização, respectivamente, do ensino pré-escolar de 4 a 5 anos, do ensino fundamental de 9 anos para as crianças de 6 a 14 anos, e do atendimento escolar para os jovens de 15 a 17 anos.

2 Ver Simões (2016).

3 Esses atributos constitutivos do conceito de acesso, conforme tratado neste trabalho, serão explicados mais adiante.
} 
Após essa introdução, na segunda seção, são pontuadas algumas dificuldades ainda presentes no planejamento educacional brasileiro quanto às metas de universalização do acesso, em particular no que toca à própria definição de acesso à escola. É recuperado o debate acadêmico sobre a universalização do acesso escolar que se travou desde meados dos anos 1980, fornecendo o pano de fundo que motiva a análise empírica que será desenvolvida nas seções seguintes. $\mathrm{Na}$ terceira seção, apresentam-se indicadores tradicionais da medida do acesso, como a taxa de frequência escolar, e recoloca-se o conceito de acesso à educação básica em termos das noções de integralidade e universalidade, passando a investigar o acesso escolar no Brasil a partir das curvas de acesso dos jovens de 19 anos $^{4}$ por seus agrupamentos de renda, cor/raça, sexo e região de moradia a partir dos dados da Pnad Contínua de 2017. A situação do acesso escolar dos jovens já excluídos da escola é discutida, buscando-se evidenciar em que etapa da educação básica se dá a evasão para os $20 \%$ mais pobres. A quarta seção compara as curvas de acesso à educação básica entre as diferentes regiões geográficas e unidades da Federação, identificando aquelas em que mais se avançou no acesso à educação básica. Na quinta seção, a desigualdade do acesso entre os $20 \%$ mais pobres e os $20 \%$ mais ricos é analisada para as diferentes regiões e unidades da Federação, identificando as regiões e estados onde os mais pobres têm maior chance de alcançar todos os anos escolares da educação básica. A sexta seção, que faz uso também dos dados da Pnad (2002, 2007 e 2012), analisa a evolução das curvas de acesso à educação básica no período 20022017 para o Brasil, regiões geográficas e unidades da Federação. A última seção busca reunir os principais achados e conclusões do trabalho.

\section{A DISCUSSÃO DO ACESSO: ASPECTOS CONCEITUAIS}

A agenda da educação nos países em desenvolvimento ganhou forte impulso a partir da Conferência Mundial de Educação para Todos, em Jomtien (Tailândia), realizada em 1990. Nessa agenda, reforçada e ajustada a seis objetivos estratégicos por ocasião do Fórum de Dakar, realizado em 2000 no Senegal, ganhou destaque o acesso universal à educação básica, de forma a assegurar que todos possam ingressar e concluir a escola básica de caráter gratuito e compulsório. A meta ganhou uma data, 2015, e determinou um dos oito objetivos de desenvolvimento do milênio, passando exercer forte influência nos acordos multilaterais e agendas nacionais de desenvolvimento. No Brasil, essa agenda se refletiu no Plano Decenal de Educação para Todos (1993-2003), nos Planos Nacionais de Educação 2001-2010 e 2014-2024. Em todos esses planos, a universalização do acesso à educação básica aparece como

\footnotetext{
${ }_{4}$ Em algumas análises, utiliza-se o grupo de 19 a 24 anos para reduzir o erro amostral.
} 
objetivo central, e metas foram estabelecidas em torno da escolaridade obrigatória ${ }^{5}$. Em todos, incluindo o atual, a meta de universalização do acesso à etapa obrigatória que corresponde ao ensino fundamental foi considerada alcançada.

Primeiramente, aspectos menos evidentes sobre o acesso escolar levaram os relatórios oficiais a declararem como alcançadas as metas de universalização da etapa obrigatória nos diversos planos de educação. O uso de médias nacionais para avaliar o progresso do acesso, por exemplo, oculta aspectos distributivos dos indicadores escolhidos para o monitoramento. Quando, por exemplo, determinados grupos sociais progridem menos rapidamente que outros - ou mesmo regridem - pode haver lacunas no acesso escolar ocultas no valor médio dos indicadores. A universalização pode ocorrer para alguns grupos sociais coexistindo situações de exclusão de outros grupos mais afetados por processos de evasão escolar.

Em segundo lugar, aspectos de equidade, embora presentes nas diretrizes dos planos de educação, foram sempre escassamente definidos em termos de metas específicas e de indicadores capazes de avaliar a distribuição dos resultados por diferentes grupos da população ${ }^{6}$. Avaliar o acesso sem considerar a equidade e sem identificar grupos excluídos (ao longo do processo de escolarização) redunda em conclusões sobre uma universalização meramente aparente, pois sem lastro na realidade social concreta que tende a apresentar desigualdades entre grupos.

Em terceiro lugar, a aparente simplicidade do conceito de acesso escolar, e de sua universalização, entendido como direito realizado à matrícula na escola e traduzido em indicadores de cobertura, atendimento ou frequência escolar, deixam sem atenção aspectos conceituais relevantes. Em parte, algumas controvérsias no debate acadêmico decorrem da multiplicidade de entendimentos sobre o significado de acesso escolar e sua universalização.

O acesso universal significaria o que de fato? Que todos na faixa etária obrigatória estejam matriculados não importando a série? Que todos que completam a idade de ingresso (agora 4 anos) estejam matriculados? Que todos completem um certo número de anos de escolaridade não importando a idade em que o fazem? Que todos completem a educação básica na idade certa? Que todos adquiram competências básicas de aprendizagem durante o tempo em que estiverem na escola? A pretensa unidade conceitual em torno da ideia de acesso se quebra rapidamente ao se pensar sobre essas questões. Há uma miríade de aspectos em torno do conceito de acesso,

\footnotetext{
5 O Plano Decenal estabeleceu a meta de que 94\% das crianças e jovens em idade escolar obrigatória (7-14 anos) estivessem frequentando a escola até 2003. O primeiro PNE (2001-2010) fixou a meta de universalização do ensino fundamental (7-14 anos) no prazo de cinco anos, ou seja, até 2006. O último PNE (2014-2024) estabelece a meta de universalização do ensino fundamental de 9 anos para a população de 6 a 14 anos. Com a Emenda Constitucional no 59/2009 é tornada obrigatória a frequência escolar dos 4 aos 17 anos, que passou a vigorar a partir de 2016.

6 Como exceção, a Meta 8 do PNE 2014-2024 estabelece que a escolaridade média de 12 anos seja alcançada para a população de 18 a 29 anos de forma a incluir as populações do campo, as regiões de menor escolaridade e os $25 \%$ mais pobres, bem como igualar a escolaridade média de negros e não negros.
} 
cuja formulação clara precede a possibilidade de se construir indicador(es) capaz(es) de avaliar o progresso em relação a metas estabelecidas.

A necessidade de elaboração conceitual sobre o acesso escolar se impõe dada a insuficiência da abordagem dominante atual. Essa insuficiência deriva da contradição evidente, por exemplo, entre o discurso difundido nos meios oficiais da universalização do acesso à educação básica e a não conclusão dessa etapa por um contingente significativo de jovens que deixam a escola. Ignora-se um fenômeno identificado por Lewin e Sabates (2012), a partir da análise de sistemas educacionais em diversos países em desenvolvimento, de que o crescimento na taxa de participação escolar é, em geral, acompanhado pela piora nas chances de os mais pobres progredirem nos anos escolares. A dificuldade de progressão dos mais pobres cria um viés social no acesso que se manifesta com a expansão dos sistemas de ensino. Nesse sentido, a taxa líquida de matrícula no ensino fundamental, por exemplo, pode crescer ao mesmo tempo em que aumenta a repetência nessa etapa para o grupo de menor renda ao longo dos anos escolares, ocasionando o que se pode chamar de "atrito" ou "viscosidade" no sistema de ensino. O resultado imediato é a progressão mais lenta desses alunos no sistema, com o aumento do número médio de anos necessários para se concluir um ano escolar da educação básica e o aumento do risco de evasão, aumentando-se assim a demanda posterior por Educação de Jovens e Adultos (EJA). No médio prazo, o viés da repetência pode levar à exclusão, em maior proporção, dos mais pobres do sistema de ensino. Reconhecer esse fenômeno e entender como ele se manifesta exige a reconceituação do acesso à educação básica.

O debate conceitual sobre o acesso escolar no Brasil e sua universalização remonta à disputa travada entre dois argumentos apresentados em meados dos anos 1980 a partir dos trabalhos de Alceu R. Ferraro (Ferrari, 1985) e Philip R. Fletcher (Fletcher, 1985). Basicamente, Ferraro irá se opor à afirmação de Fletcher de que o acesso escolar das crianças em idade de frequência obrigatória (de 7 a 14 anos à época) estaria praticamente universalizado já no início dos anos 1980, destacando que o problema da evasão e dos excluídos da escola seria subestimado por Fletcher.

Fletcher (1985), usando um modelo de fluxo escolar, argumenta que as estatísticas educacionais oficiais deram suporte à falsa ideia de que as taxas de repetência no Brasil eram próximas às dos demais países latino-americanos e que a evasão, essa sim, ocorria em grandes números ${ }^{8}$. Ao longo do tempo, a interpretação

\footnotetext{
O sobrenome Ferrari do autor foi retificado em 1993 para Ferraro (Ferraro; Machado, 2002, p. 213).
}

8 Fletcher argumenta que na categoria de "alunos novos" na $1^{\mathrm{a}}$ série do então ensino de $1^{\mathrm{o}}$ grau das estatísticas oficiais do MEC havia de fato um número muito maior de alunos do que a população em idade de 7 anos. A conclusão do autor é de que entre os "alunos novos" havia muitos repetentes, levando a subestimação do percentual de repetentes do sistema de ensino. Isso ocorria por um "erro" de classificação dos alunos que abandonavam a escola (muitas vezes incentivados pelos professores) e entravam no ano letivo seguinte como "alunos novos", já que estes não chegavam a ser reprovados no ano anterior por terem deixado a escola antes dos exames finais. Ou, ainda, da classificação como "alunos novos" dos reprovados que se transferiam de escola. Ou seja, a estatística oficial dos repetentes 
dos dados oficiais fortaleceu a tese de que as crianças deixavam a escola (evasão) por razões fora do alcance do trabalho escolar. Nesse caso, as condições socioeconômicas das famílias, a cultura popular ou o pouco interesse dos pais pela escolarização dos filhos levaria à retirada das crianças da escola já nos primeiros anos de escolarização. Em contraste, a repetência, enquanto problema diretamente ligado às práticas pedagógicas no espaço escolar, é identificada por Fletcher como recebedora de pouca atenção como fator determinante do abandono precoce e principal causa da evasão escolar ${ }^{9}$. Ainda, esse autor vai identificar a reprovação como um recurso profissional dos professores, incentivado pelos sistemas de ensino, como resposta ao baixo empenho e desempenho do aluno, a quem é atribuída a responsabilidade pelo seu próprio fracasso. A conclusão do autor é de que, contrariamente à ideia dominante, os alunos perseveram na escola anos a fio, mas acumulando repetências, o que, por fim, acaba levando à evasão em idades mais avançadas e sem a escolarização obrigatória concluída, embora permaneçam tempo suficiente na escola para fazê-lo (oito anos em média). O autor identifica que 94,8\% da geração de 1979 havia se matriculado no primeiro grau, estando este nível de ensino disponível praticamente para a totalidade das crianças em idade escolar.

Atacando o que chamam dos onze mitos do ensino de $1^{\circ}$ Grau, Fletcher e Castro (1986) destacam dois que buscam desconstruir: (i) uma proporção significativa da população em idade escolar não teria acesso ao ensino de $1^{\circ} \mathrm{Grau}$; (ii) o principal problema do ensino de $1^{\circ}$ Grau é a evasão. Os autores concluem, com base nos dados da Pnad 1982, que aproximadamente 95\% da população em idade escolar obrigatória teria tido acesso ao ensino de $1^{\circ}$ grau, restando incluir a população da área rural da região Nordeste. Para eles, não se sustentaria a ideia de que parte expressiva da população brasileira não teria acesso à escola obrigatória. Como já argumentado em Fletcher (1985), haveria nas estatísticas oficiais do MEC uma sobrestimação da taxa de evasão e uma subestimação da taxa de repetentes entre as séries escolares, em particular da primeira para a segunda. Em vez da evasão, os autores centram na eliminação da repetência o foco que deve ser dado para que se consiga simultaneamente a ampliação do acesso ao sistema de ensino (aqui subentendidas as séries mais elevadas) e a redução da própria evasão. Sugerem inclusive, como já o havia feito Anísio Teixeira (1954), que se considere a alternativa da promoção automática como política para se

incluía apenas aqueles que haviam sido reprovados no ano letivo anterior e que voltavam a se matricular na mesma escola. Uma vez que o grande número de "alunos novos" na $1^{\mathrm{a}}$ série era acompanhado de um número muito menor de alunos na $2^{\mathrm{a}}$ série (numa razão de 100 para 46 no biênio 1968/1969), a conclusão aparentemente óbvia, mas falsa, era de que a diferença observada era devido à evasão do sistema de ensino. Daí as taxas de evasão oficiais se apresentarem muito altas e as de repetência muito baixas em relação ao que Fletcher irá apurar em seu trabalho.

9 O autor aponta que em uma revisão de 1.706 artigos e relatórios de pesquisa produzidos no Brasil durante a década de setenta somente doze trataram da repetência, sendo que apenas três ou quatro possuíam qualidade digna de nota. 
resolver a ineficiência do sistema de ensino traduzida pelo alto custo associado ao número médio de anos necessário para se avançar uma série escolar.

Na mesma linha e em colaboração com Fletcher, Sérgio Costa Ribeiro, em seu clássico artigo "A pedagogia da repetência” (Ribeiro, 1991), confronta os dados oficiais do MEC para as taxas de repetência, promoção e evasão com os resultados obtidos com base na análise do modelo de fluxo escolar usando dados do Censo Demográfico e da Pnad. Enquanto os dados oficiais apontavam, para a $1^{\mathrm{a}}$ série, índices de repetência de cerca de $30 \%$ e de evasão de aproximadamente $25 \%$, as estimativas de Ribeiro (1991) produzem resultados muito distintos, sendo 52\% para a repetência e apenas 2,3\% para a evasão no ano de 1982. O fenômeno do abandono durante o ano letivo com rematrícula no ano seguinte na mesma escola ou a transferência de escola após sofrer reprovação no final do ano são contabilizados na estatística oficial como “alunos novos". Esses são os erros metodológicos que, segundo Ribeiro (1991), estão na raiz das discrepâncias encontradas, repercutindo o que já havia sido apontado por Fletcher (1985). Ribeiro vai afirmar que:

Pelos dados do PROFLUXO, cerca de 93\% de uma geração têm acesso à escola no Brasil hoje. Este dado, por si só, evidencia que o acesso à escola de $1^{\circ}$ Grau está praticamente universalizado no País. (Ribeiro, 1991, p. 9).

A abordagem inaugurada por Fletcher e Castro (1986) e Ribeiro (1991) vai trazer a qualidade do ensino para o centro do debate educacional, já que a reprovação e a repetência de grandes contingentes de alunos passam a ser associadas às práticas pedagógicas, à qualidade e às condições de trabalho dos professores e ao padrão de oferta material das escolas.

A discordância de Alceu R. Ferraro com o argumento de Fletcher e Castro (1986) e Ribeiro (1991) é menos sobre os erros encontrados nas estatísticas oficiais ou sobre a relevância da reprovação e repetência escolar como causas fundamentais da evasão escolar. A discordância é, sobretudo, quanto à afirmação de que o ensino obrigatório de $1^{\circ}$ grau estaria praticamente universalizado no Brasil já no início dos anos 1980 e de que a evasão seria um problema menor. Para Ferraro, isso omitiria o fato de que, por um lado, certos grupos sociais ainda teriam dificuldade de ingresso na escola ou, se ingressassem, teriam alta probabilidade de evadir antes de concluírem o ensino obrigatório (os excluídos da escola), ou ainda, estariam na escola com forte atraso escolar, portanto em forte risco de exclusão (os excluídos na escola).

A origem da controvérsia pode estar mais no uso livre dos termos "acesso" e "universalização" que fazem esses autores. Ribeiro quando se refere ao acesso à escola e à educação básica, por exemplo, diz que o principal obstáculo à universalização da educação básica em nosso país é a repetência (Ribeiro, 1991). Oferece, ainda, uma cifra alarmante ao dizer que $65 \%$ da população de 15 a 39 anos de idade nunca iria terminar os oito anos de escolaridade obrigatória. Portanto, está longe de considerar que o ensino fundamental estaria universalizado quando se trata de olhar a sua 
integralidade. O uso dos conceitos de acesso e universalização sem o cuidado de defini-los e contextualizá-los pode estar na origem das controvérsias entre esses autores, que trouxeram contribuições inestimáveis à compreensão do processo de escolarização e de suas dificuldades.

Para compreender o enfoque na análise de Ferraro e sua posição assertiva sobre a não universalização do acesso à escolarização obrigatória (posição que também é sustentada neste trabalho), são apresentados a seguir, de forma resumida, seus principais argumentos.

Ao analisar o problema do analfabetismo e os resultados do programa instituído na década de 1970, durante o período militar, para combater tal problema - o Movimento Brasileiro de Alfabetização (Mobral) -, Ferraro (Ferrari, 1985, 1987) identificou o fracasso do objetivo traçado no Plano Setorial de Educação e Cultura do governo militar (1972-1974) de "secar" a fonte de analfabetismo no país por meio da universalização do ensino fundamental dos 7 aos 14 anos. O autor constata, com base nos dados do Censo Demográfico de 1970 e 1980, um aumento no número absoluto de analfabetos na faixa etária de 7 a 14 anos da ordem de 730 mil na década, totalizando 8,4 milhões de analfabetos naquela faixa etária em 1980. A produção do analfabetismo se daria pelo processo de exclusão escolar, em que 7,6 milhões de crianças (33\% da população em idade escolar obrigatória) se encontravam excluídas da escola e, ainda, em que outros 6,4 milhões (28\%) estavam fortemente defasados na relação idade-série (excluídos na escola), compondo os prováveis excluídos da escola no futuro. Esses resultados denunciavam a falência do projeto de universalização do acesso da década de 1970, esboçado no referido Plano Setorial, bem como a falência do Mobral como política de redução do analfabetismo ${ }^{10}$.

Em estudo posterior, usando dados da contagem populacional de 1996 que desagregou as pessoas em idade escolar que não frequentavam a escola entre os que nunca frequentaram e os que já frequentaram anteriormente, Ferraro e Machado (2002) mostram que, do total de crianças nos grupos de 7 a 14 e de 15 a 17 anos que não frequentavam a escola, cerca de 1,5 milhão nunca havia se matriculado. Entre 5 e 6 anos, quase 2 milhões também nunca haviam frequentado (Ferraro; Machado, 2002). O dado desagregado permitiu que Ferraro identificasse os evadidos por idade, evidenciando também a relevância numérica da evasão no ensino fundamental. Em estudo anterior, sobre a reprodução do analfabetismo no Rio Grande do Sul (Ferraro, 1997), o autor identificara que a evasão em idade avançada embora ocorresse, não respondia por todo o problema da evasão. O trabalho infantil de 10 a 14 anos, e mesmo de crianças menores de 10 anos, teria impacto na decisão de frequentar ou não a escola, contribuindo assim para a evasão escolar.

\footnotetext{
${ }^{10} \mathrm{O}$ autor identifica que houve redução do analfabetismo absoluto na faixa de 15 a 39 anos da ordem de um milhão de pessoas, faixa que incluía o público-alvo prioritário do Mobral (que era de 15 a 34 anos). Ocorre que, para todos os demais grupos da população, houve de fato aumentos expressivos no número de analfabetos. O número absoluto de analfabetos só viria a recuar pela primeira vez no Brasil em 1984.
} 
É com base nessas evidências que Ferraro irá discordar da afirmação sobre a universalização do acesso e da minimização do problema da evasão, mesmo em relação ao ensino fundamental (Ferraro, 1999), que ganha força no final dos anos 1980, como sustentado por Fletcher e Castro (1986) e Ribeiro (1991).

Analisando o acesso escolar sob a perspectiva da exclusão como processo de produção do sistema educacional, mais do que um mero "estado" ou "condição" de estar fora da escola, Ferraro e Ross (2017) apontam a necessidade de transformação da escola e da lógica da exclusão que rege o seu funcionamento. A mera inclusão dos que estão fora não eliminaria os mecanismos internos à escola e ao sistema de ensino que operam na produção dos "excluídos na escola", potenciais "excluídos da escola” em futuro próximo. Contudo, a exclusão como categoria analítica se limitaria, na avaliação dos autores, a descrever os limites objetivos ao acesso escolar, não sendo, contudo, capaz de explicar o fenômeno do não acesso ou do acesso incompleto.

É em outro artigo recente que Ferraro discute quatro perspectivas teóricas que fundamentam diferentes abordagens ao problema do acesso à educação (Ferraro, 2018). $\mathrm{O}$ autor as organiza na forma de antinomias: (i) exclusão-inclusão; (ii) igualdadedesigualdade; (iii) direito-dívida; (iv) fracasso-sucesso. A última dessas abordagens é apontada como equivocada por atribuir aos alunos toda a responsabilidade pelo desempenho escolar e, portanto, o insucesso e a eventual evasão escolar tenderiam a ser colocados apenas do lado da demanda.

A perspectiva da exclusão-inclusão, embora útil na descrição dos contingentes excluídos, exigiria uma clara definição do uso dessa categoria analítica dada a sua multiplicidade de sentidos (Ferraro; Oliveira; Ribeiro, 1999), sendo necessário, ainda, ir além dessa descrição e examinar os mecanismos escolares de produção da exclusão. O limite dessa abordagem estaria em induzir ao pensamento de que o problema do acesso se resolveria apenas pela inclusão dos excluídos. Contudo, para resolver tal problema, não bastaria incluí-los. Para tanto, seria necessário evitar as práticas de exclusão que comprometem a permanência e a conclusão da educação básica e que operam no interior da escola - ou "deixar de excluir", como afirma Ferraro (2018, p. 321).

É nas abordagens da igualdade-desigualdade e do direito-dívida que Ferraro (2018) identifica as perspectivas teóricas mais promissoras para o diagnóstico do problema do acesso escolar e sua universalização. Por um lado, as desigualdades materializadas em diversos planos da existência humana, segmentando grupos sociais em função do seu nível de renda, local de moradia, raça, gênero etc., produziria a exclusão social e, por conseguinte, a exclusão das oportunidades e ofertas educacionais. Por outro, a exclusão social também seria reprodutora das desigualdades e produtora do seu agravamento na medida em que privaria os indivíduos de determinados grupos sociais das oportunidades e ofertas que lhes possibilitariam superar a condição de desvantagem que os distancia dos demais. Ainda, essas abordagens articuladas 
associam o princípio da igualdade formal gravada nos direitos civis, políticos e sociais ao direito universal à educação e à igualdade de oportunidades educacionais, criando a obrigação do Estado moderno na garantia desse direito subjetivo e indisponível.

Na esteira da reflexão de Ferraro (2018), é possível pensar que o direito à educação, conforme estabelecido na Constituição Federal de 1988, possa avançar em termos do direito à aprendizagem e, por conseguinte, do direito a progredir na trajetória escolar até a conclusão da educação básica na idade recomendada. A forma como o direito à educação foi incluído na Constituição limita o dever do Estado praticamente à oferta do ensino público e gratuito na idade obrigatória (art. 208, inc. I) e à oferta de programas suplementares (art. 208, inc. VII). Não obstante a garantia de igualdade de condições para o acesso e permanência na escola (art. 206, inc. I) e de padrão de qualidade (art. 206, inc. VII), a insuficiência dessa formulação no campo dos direitos e deveres fica patente na constatação de que o direito à educação básica não se concretizou, ainda hoje, para parcelas não desprezíveis da população brasileira, como será discutido nas próximas seções.

\section{ACESSO À EDUCAÇÃO BÁSICA NO BRASIL: A UNIVERSALIZAÇÃO COLOCADA À PROVA}

\subsection{A DESIGUALDADE NA FREQUENNCIA ESCOLAR}

A frequência escolar em idade obrigatória tem sido o critério dominante para se avaliar se foi alcançada a universalização do acesso à educação básica. Não obstante a sua limitação para compreender o que ocorre durante a trajetória escolar, o uso da taxa de frequência à escola por idade pode ser um ponto de partida para se avaliar o perfil do acesso compreendido como matrícula em fase de escolaridade obrigatória ${ }^{11}$. O Gráfico 1 mostra a taxa de frequência escolar ajustada para a população de 4 aos 24 anos. Essa taxa exclui do universo os jovens que, em 2017, já haviam concluído o ensino médio. Antes dos 6 anos e a partir dos 15 anos de idade se percebe uma diminuição na taxa de frequência escolar. Aos 17 anos de idade cerca de um em cada seis jovens que não concluíram o ensino médio estão fora da escola, quando esta é ainda idade obrigatória de frequência à escola. Aos 18 anos, com o término da obrigatoriedade legal, a taxa de frequência escolar cai significativamente, ficando abaixo de $65 \%$.

\footnotetext{
${ }^{11}$ A Emenda Constitucional no 59, de 11 de novembro de 2009, alterou o inciso I, artigo 208, da Constituição estabelecendo como obrigatória e gratuita a educação básica dos 4 aos 17 anos.
} 


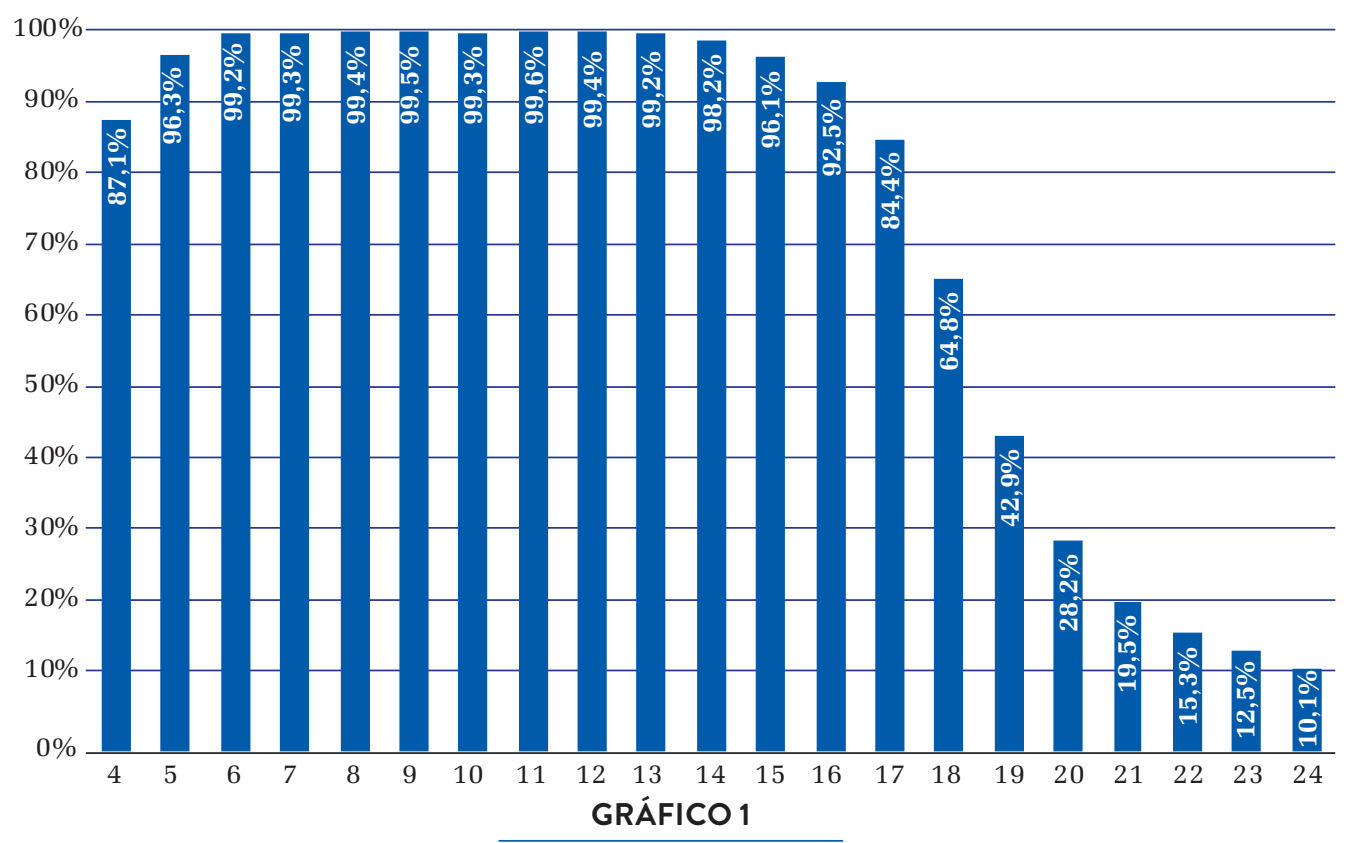

TAXA DE FREQUÊNCIA ESCOLAR, POR IDADE - BRASIL - 2017

Fonte: Elaboração própria com base em dados de Pnad Contínua / IBGE (2017).

A desagregação da taxa de frequência escolar para a população dos $20 \%$ mais pobres e dos $20 \%$ mais ricos, em termos da renda domiciliar per capita, mostra a desigualdade brasileira na participação escolar já antes dos 6 anos e a partir dos 14 anos, se acentuando muito dos 15 anos em diante (Gráfico 2).

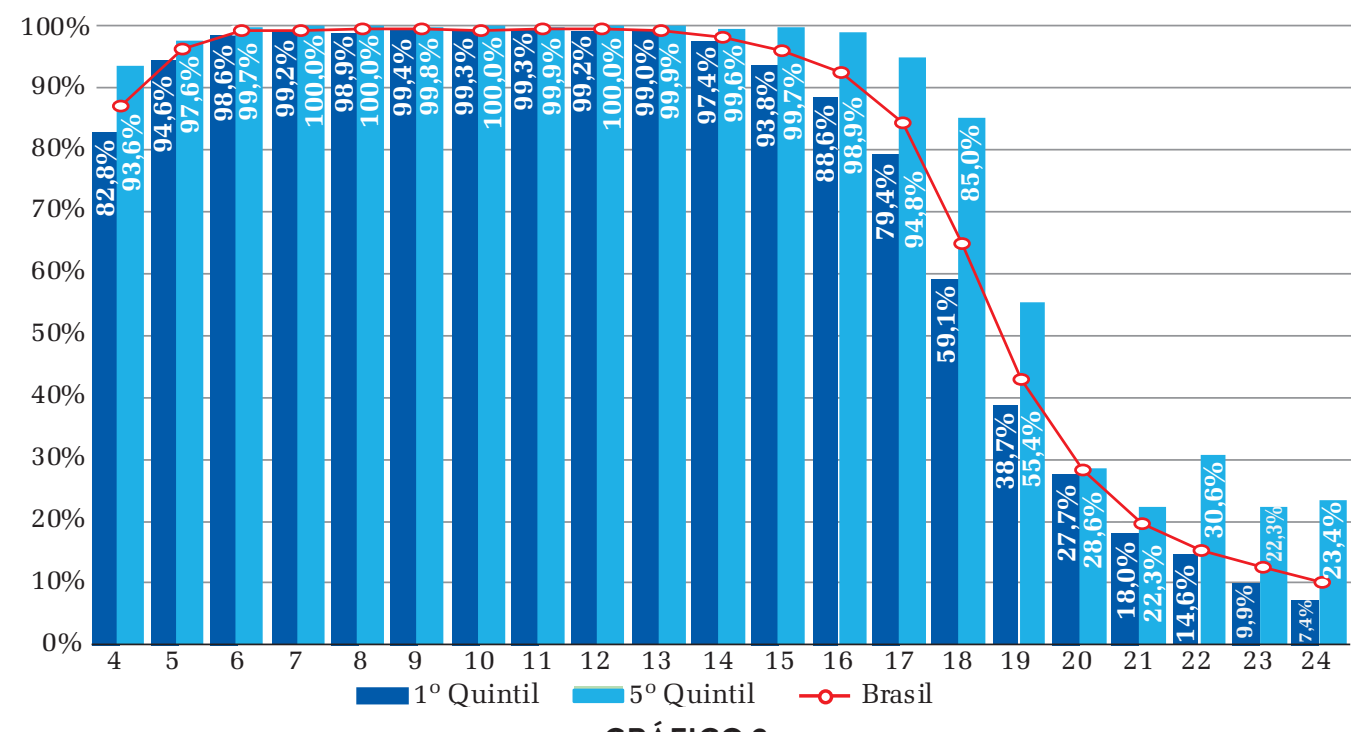

GRÁFICO 2

TAXA DE FREQUÊNCIA ESCOLAR, POR IDADE $\left(1^{\circ} \mathrm{E} 5^{\circ}\right.$ QUINTIS DE RENDA DOMICILIAR PER (APITA) - BRASIL - 2017

Fonte: Elaboração própria com base em dados de Pnad Contínua / IBGE (2017). 
A universalização do acesso enfrenta dificuldades ainda que se utilize o critério simples da frequência escolar na idade obrigatória. Ao todo, em 2017, o Brasil tinha cerca de 1,5 milhão de crianças e jovens entre 4 e 17 anos fora da escola, representando $3 \%$ do total nessa faixa etária que não havia concluído a educação básica. Desse total, $57 \%$ se concentravam no grupo de 15 a 17 anos de idade, somando cerca de 850 mil de jovens (Gráfico 3).

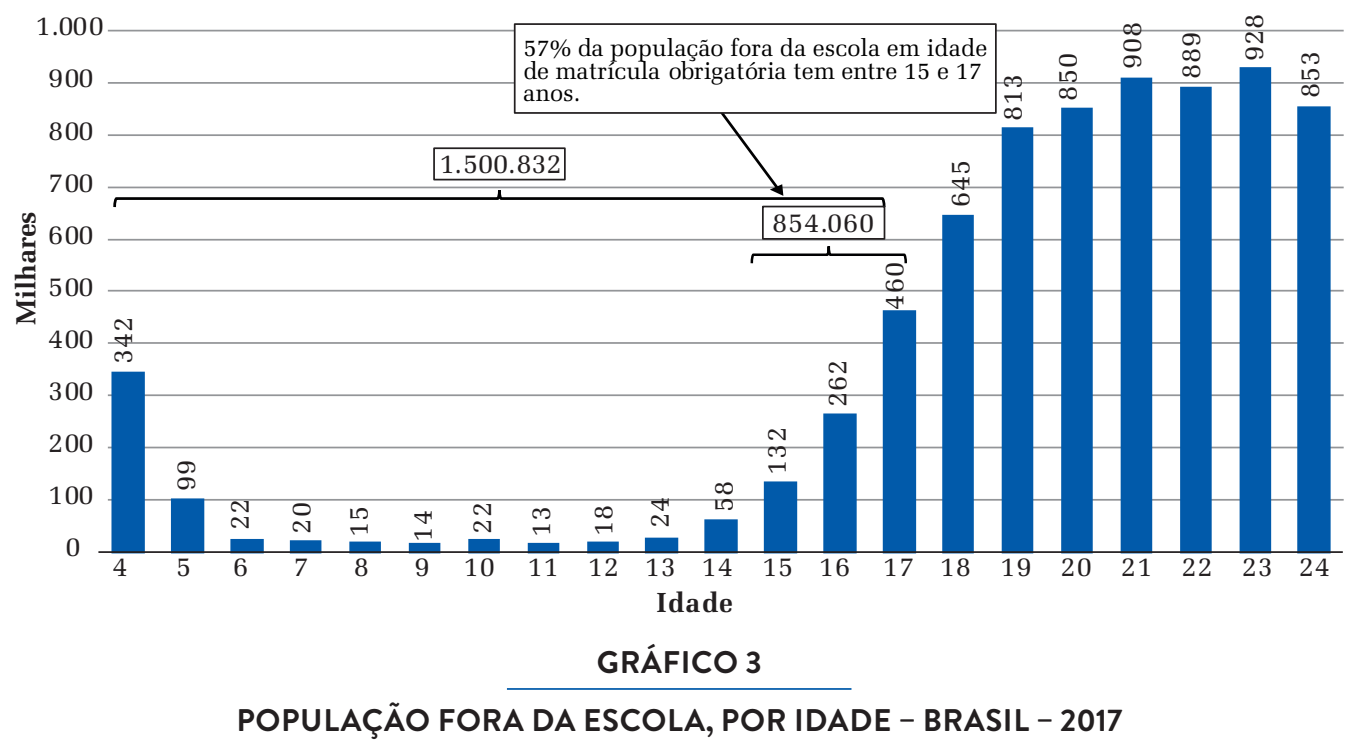

Fonte: Elaboração própria com base em dados de Pnad Contínua / IBGE (2017).

O 1,5 milhão de crianças e jovens fora da escola não se distribuem igualmente entre os estratos de renda (Gráfico 4). Há uma forte concentração de excluídos da escola nos dois primeiros quintis de renda domiciliar per capita (os 40\% mais pobres), que concentram 73\% dos excluídos do grupo de 4 a 5 anos, $80 \%$ dos excluídos de 6 a 14 anos e $73 \%$ dos excluídos de 15 a 17 anos. Ao todo, para os $20 \%$ mais pobres, a taxa de exclusão na faixa de 4 a 17 anos é de $4 \%$, enquanto, para os $20 \%$ mais ricos, chega, em 2017, a 0,7\%. 


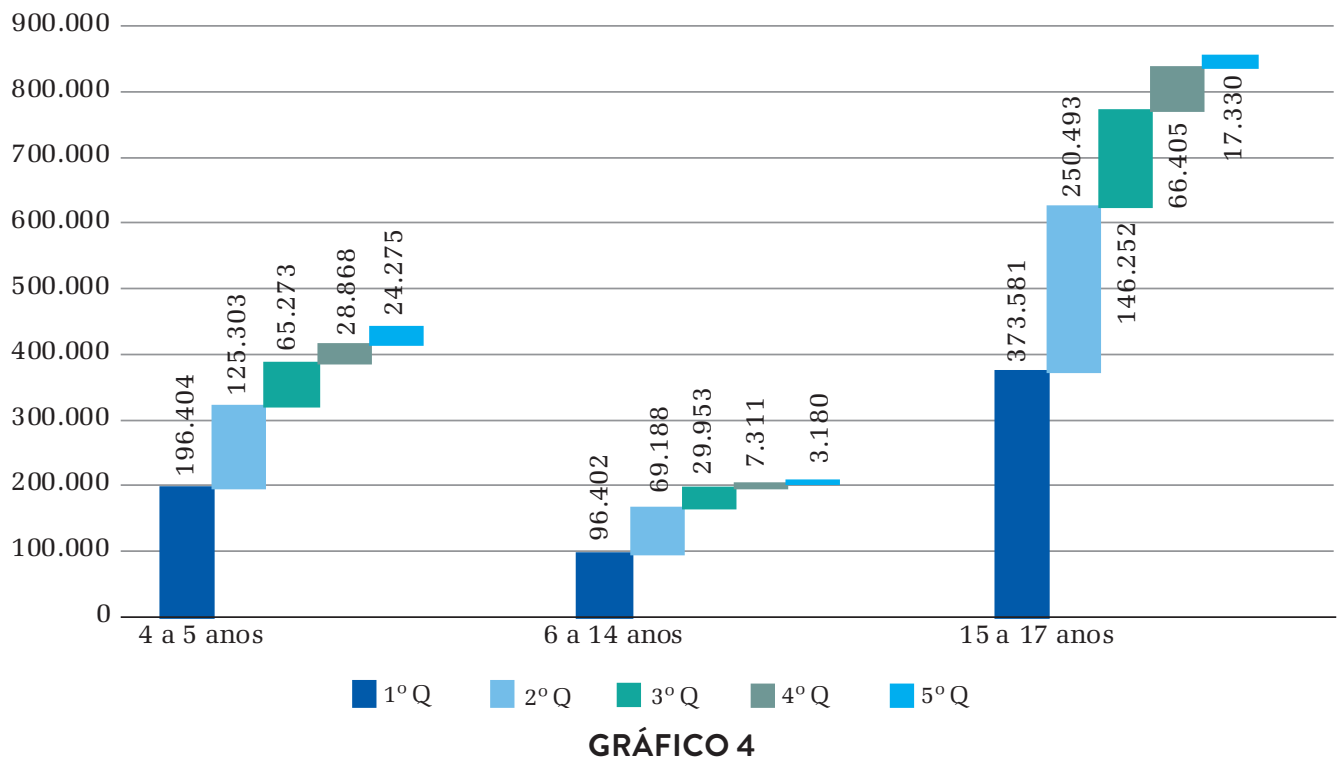

POPULAÇÃO EM IDADE ESCOLAR FORA DA ESCOLA, POR GRUPO DE IDADE, SEGUNDO O QUINTIL DE RENDA DOMICILIAR PER CAPITA - BRASIL - 2017

Fonte: Elaboração própria com base em dados de Pnad Contínua / IBGE (2017).

Portanto, ainda que se restrinja o conceito de acesso à frequência escolar em idade obrigatória, é possível dizer que não há universalização do acesso quando um segmento não desprezível de crianças e jovens estão excluídos dessa frequência, em particular aqueles pertencentes aos $40 \%$ mais pobres da população.

\subsection{AVALIANDO O ACESSO ESCOLAR NA PERSPECTIVA DA INTEGRALIDADE E UNIVERSALIDADE}

Se expandirmos o conceito de acesso escolar para incluir o aspecto da integralidade, ou seja, que os brasileiros logrem não apenas se matricular, mas que alcancem também todos os anos escolares da educação básica, de preferência na idade recomendada e, ainda, o aspecto da universalidade, ou seja, que todos possam ter acesso a todos os anos escolares independente do nível socioeconômico de sua família, de condições de raça/cor, gênero, local de residência ou qualquer outro fator de natureza demográfica ou socioeconômica, então a universalização do acesso à educação básica certamente ainda está por ser alcançada.

Utilizando o indicador gráfico curva de acesso $^{12}$ é possível verificar a trajetória de acesso à educação básica para diferentes grupos de idade, nível de renda, unidades da Federação etc., identificando as desigualdades existentes e os padrões com que tais desigualdades se replicam e evoluem no tempo.

$\overline{12 \text { Ver Simões (2016) }}$ 
A curva de acesso dos jovens de 19 anos no Brasil em 2017 (Gráfico 5) permite identificar que percentual dos jovens teve acesso aos anos escolares da educação básica até aquele ano. No Brasil, praticamente todos os jovens que tinham completado 19 anos até o segundo trimestre de $2017^{13}$ tiveram acesso ao ensino fundamental nos anos iniciais, tendo $98,2 \%$ alcançado o $5^{\circ}$ ano do ensino fundamental. Esse indicador nos permite dizer que, no Brasil, a geração que completava 19 anos em 2017 teve, em média, praticamente universalizado o acesso às séries iniciais do ensino fundamental ${ }^{14}$. Todavia, a partir do $6^{\circ}$ ano do ensino fundamental, há o início do "atrito" no acesso escolar, ou seja, a curva de acesso mostra que uma fração dos jovens não logrou alcançar os anos finais dessa etapa da educação básica, sendo que apenas $88,6 \%$ chegaram ao $9^{\circ}$ ano do ensino fundamental. O acesso ao ensino médio foi ainda mais comprometido, visto que só $82,5 \%$ dos jovens teve acesso ao $1^{\circ}$ ano dessa etapa e apenas $67,5 \%$ chegou ao $3^{\circ}$ ano. Temos, portanto, 32,5\% dos jovens de 19 anos no Brasil que, até 2017, não lograram alcançar o final do ensino médio, cerca de um em cada três.

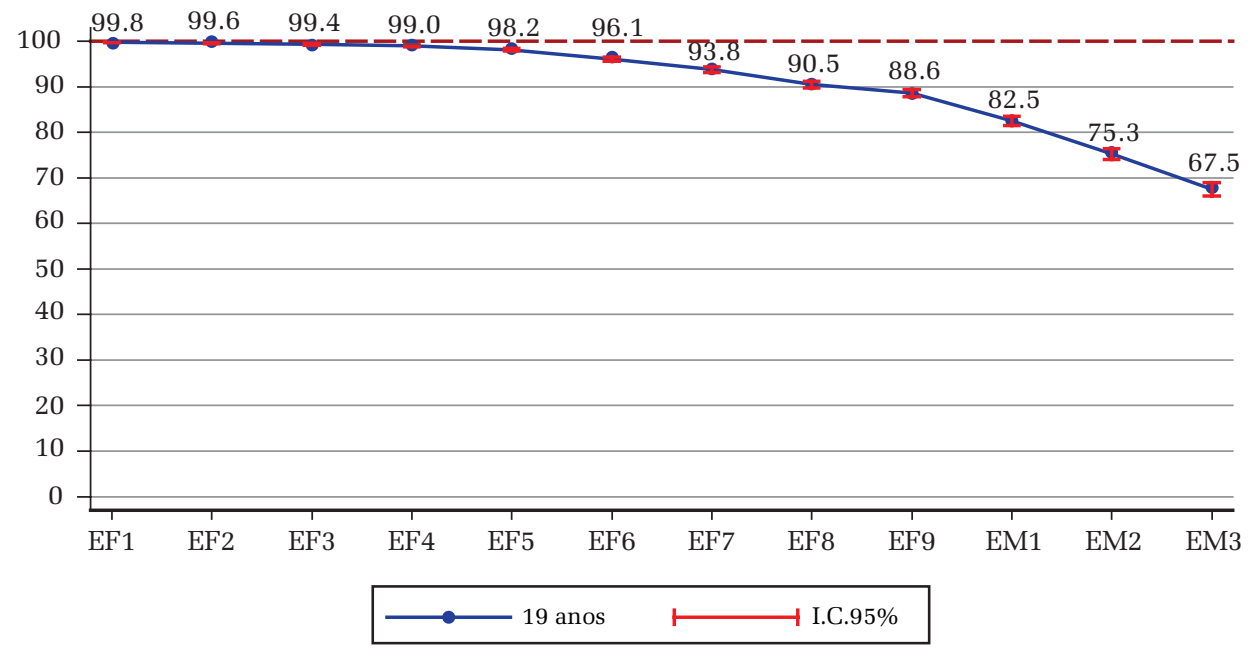

GRÁFICO 5

CURVA DE ACESSO DOS JOVENS DE 19 ANOS - BRASIL - 2017

Fonte: Elaboração própria com base em dados de Pnad Contínua / IBGE (2017).

Cerca de um terço dos jovens de 19 anos que não havia alcançado o fim da escola básica até o ano de 2017 se distribui entre os que ainda estudavam com atraso

\footnotetext{
${ }^{13}$ A Pnad Contínua realiza coletas trimestrais de dados durante o ano. Neste trabalho, são utilizados os microdados da coleta referente ao segundo trimestre, pois é neste trimestre que é aplicado o suplemento de educação da pesquisa.

${ }^{14}$ É importante ressaltar que essa afirmação se aplica à média dos jovens de 19 anos, havendo grupos específicos para os quais o acesso não se concretiza nesse mesmo patamar, mesmo para os anos iniciais do ensino fundamental (a ser visto mais adiante neste trabalho).
} 
escolar ${ }^{15}$ e os que já haviam evadido da escola. O Gráfico 6 mostra o percentual de jovens entre 15 e 24 anos que não havia alcançado o $3^{\circ}$ ano do ensino médio no ano de 2017 por condição de frequência escolar (estuda ou não estuda). Entre os jovens de 19 anos nessa condição, aproximadamente um terço ainda frequentava a escola. Os dois terços que já haviam evadido sem concluir a educação básica representam cerca de 730 mil jovens ${ }^{16}$. Vê-se que perto de um quarto dos jovens de 19 a 24 anos não havia concluído a educação básica e não frequentava a escola em 2017.

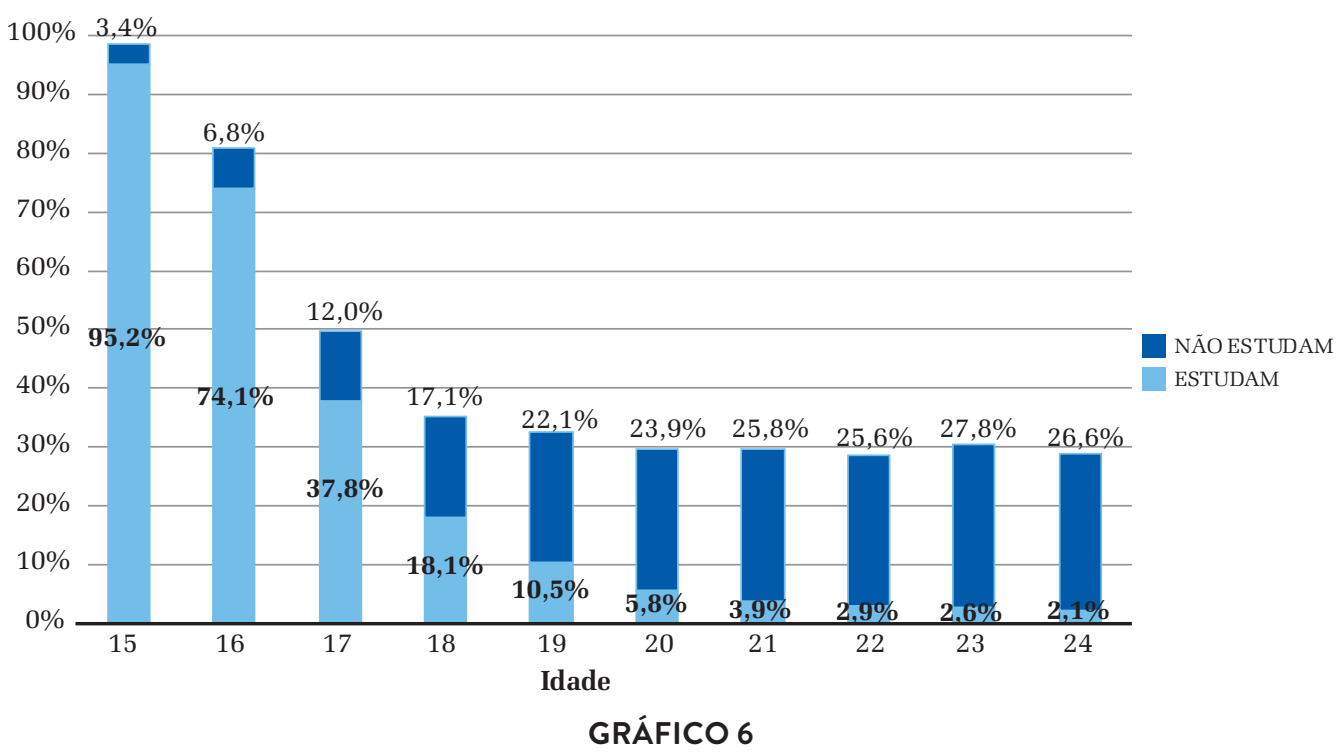

PERCENTUAL DE JOVENS DE 15 A 24 ANOS QUE NÃO HAVIA ALCANÇADO O $3^{\circ}$ ANO DO ENSINO MÉDIO, POR CONDIÇÃO DE FREQUÊNCIA ESCOLAR - BRASIL 2017

Fonte: Elaboração própria com base em dados de Pnad Contínua / IBGE (2017).

Os cerca de 350 mil jovens de 19 anos que não alcançaram o $3^{\circ}$ ano do ensino médio e frequentam a escola estão em grande parte no ensino médio, seja no regular $(59,9 \%)$ ou na Educação de Jovens e Adultos - EJA (11,0\%). Os demais que ainda frequentam a escola estão no ensino fundamental, seja no regular $(15,5 \%)$ ou EJA $(12,7 \%)$. Uma parcela muito pequena, correspondendo a menos de $1 \%$ do total dos que estudam, frequenta a alfabetização de adultos (Gráfico 7).

\footnotetext{
${ }^{15}$ Aos 19 anos é esperado que o jovem já tenha concluído a educação básica.

${ }^{16}$ Os Gráficos A-1 e A-2, no apêndice, fornecem, respectivamente, a distribuição em números absolutos e em percentual de jovens de 15 a 24 anos por situação quanto à conclusão da educação básica e à frequência escolar.
} 


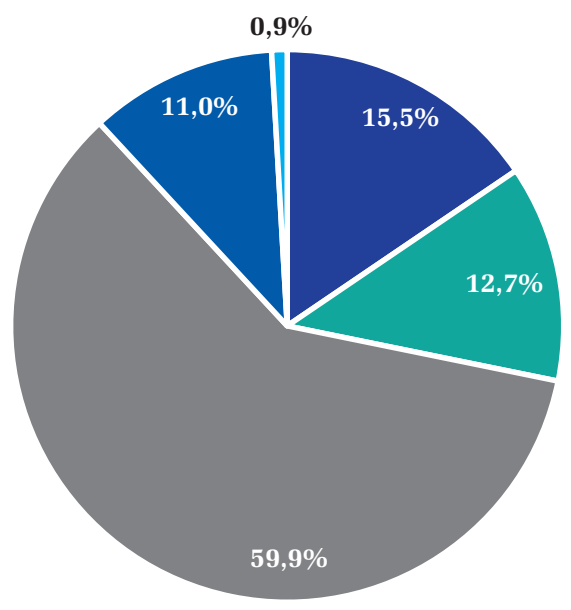

Ensino fundamental regular

EJA Ensino fundamental

Ensino médio regular

EJA Ensino médio

Alfabetização de jovens e adulto

\section{GRÁFICO 7 \\ DISTRIBUIÇÃO DOS JOVENS DE 19 ANOS QUE NÃO ALCANÇARAM O $3^{\circ}$ ANO DO ENSINO MÉDIO E QUE FREQUENTAM A ESCOLA, POR NIVVLL DE ENSINO QUE FREQUENTAM - BRASIL - 2017}

Fonte: Elaboração própria com base em dados de Pnad Contínua / IBGE (2017).

A desagregação da curva de acesso por nível da renda domiciliar per capita, sexo, cor/raça e local de moradia (urbano/rural) mostra que grupos sociais distintos apresentam trajetórias também distintas no acesso escolar (Figura 1).

As curvas de acesso mostram que, entre os grupos analisados de jovens de 19 anos, as mulheres, os brancos, os moradores de áreas urbanas e os mais ricos apresentam vantagem quanto ao acesso escolar. A renda domiciliar per capita responde pela maior desigualdade observada na curva de acesso dos jovens de 19 anos entre as caraterísticas examinadas. Enquanto entre os $20 \%$ mais ricos, $91,8 \%$ haviam chegado ao $3^{\circ}$ ano do ensino médio, entre os $20 \%$ mais pobres apenas cerca de metade dos jovens o fez. A desigualdade de acesso entre o quintil superior e inferior de renda se manifesta e cresce durante a segunda etapa do ensino fundamental (+16,5 p.p.) e se acentua na transição para e durante o ensino médio ( $+22,8$ p.p.), alcançando 42 p.p. no $3^{\circ}$ ano do ensino médio. A renda familiar aparece, portanto, como a característica mais fortemente associada à chance de o jovem de ter acesso, em sua trajetória escolar, a todos os anos de escolarização da educação básica.

As desagregações da curva de acesso (Figura 1) sugerem que, para os anos iniciais do ensino fundamental, praticamente não há desigualdade entre os grupos analisados. Já a partir do $6^{\circ}$ ano, observa-se a brecha de acesso surgir e se expandir até o final do ensino médio. Contudo, como se verá a seguir, há ainda grupos sociais para os quais mesmo o acesso aos anos iniciais do ensino fundamental não está assegurado. 

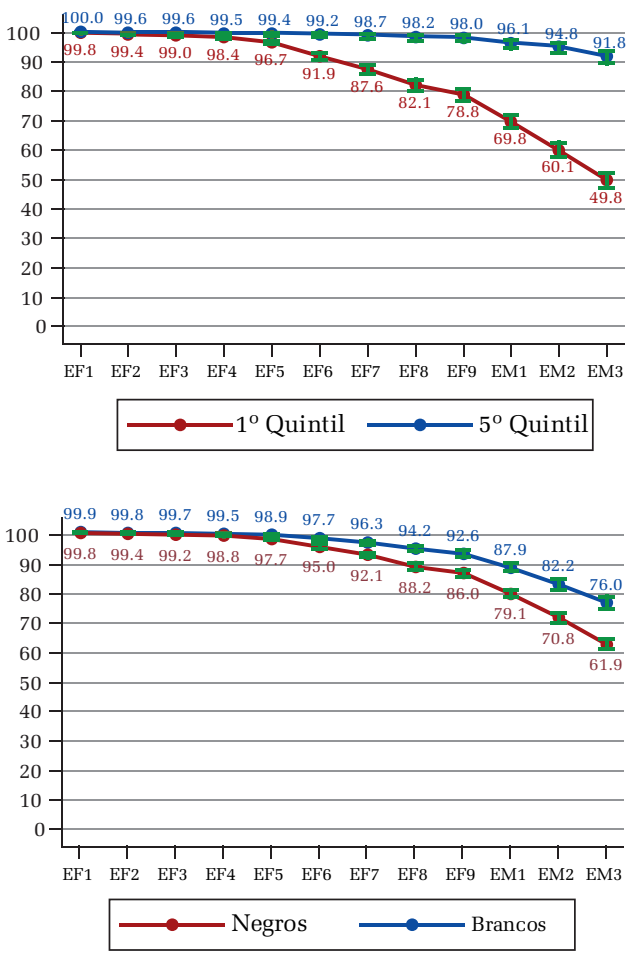

\section{FIGURA 1}

DESAGREGAÇÃO DA CURVA DE ACESSO DOS JOVENS DE 19 ANOS, POR SEXO, COR, LOCAL DE MORADIA E QUINTIS DE RENDA DOMICILIAR PER CAPITA - BRASIL - 2017

Fonte: Elaboração própria com base em dados de Pnad Contínua / IBGE (2017).

As características dos jovens interagem e podem somar ou diminuir seus "efeitos" individuais sobre o resultado observado da trajetória escolar, descrito aqui na curva de acesso. Observar as curvas de acesso para grupos de jovens formados pela combinação de tais características permite avaliar os grupos em maior desvantagem no acesso escolar no Brasil. O Gráfico 8 mostra as curvas de acesso para os grupos de jovens de 19 a $24^{17}$ anos formados pela combinação das características de renda, cor/ raça e sexo.

Pode-se observar um padrão na desvantagem do acesso escolar a partir das curvas assim desagregadas. Primeiramente, notam-se duas zonas de acesso bem distintas, uma do grupo de menor renda domiciliar per capita (os 20\% mais pobres) e outra do grupo de maior renda (os 20\% mais ricos). Em cada uma dessas duas zonas, o mesmo padrão se repete quanto às demais características dos grupos. Os jovens negros apresentam o menor acesso escolar tanto entre os mais pobres quanto entre

\footnotetext{
${ }_{17}$ As estimativas para gerar as curvas de acesso são feitas para o grupo de 19 a 24 anos para reduzir o erro amostral resultante da desagregação por três características.
}
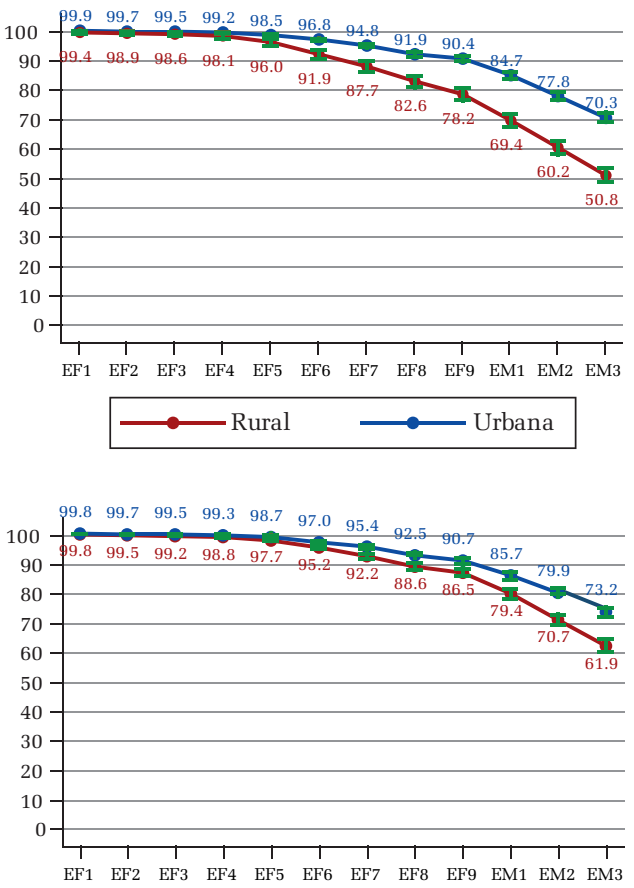

\section{.}


os mais ricos, o que revela um viés seletivo racial associado aos homens no baixo acesso escolar no Brasil. Os homens brancos e as mulheres negras apresentam curvas de acesso muito próximas ${ }^{18}$ e superiores a dos homens negros para os dois quintis de renda domiciliar per capita. Por último, as mulheres brancas apresentam vantagem no acesso escolar nos dois grupos de renda, havendo diferença estatística em relação aos grupos das mulheres negras e dos homens brancos, sendo essa distinção mais clara no primeiro quintil de renda.

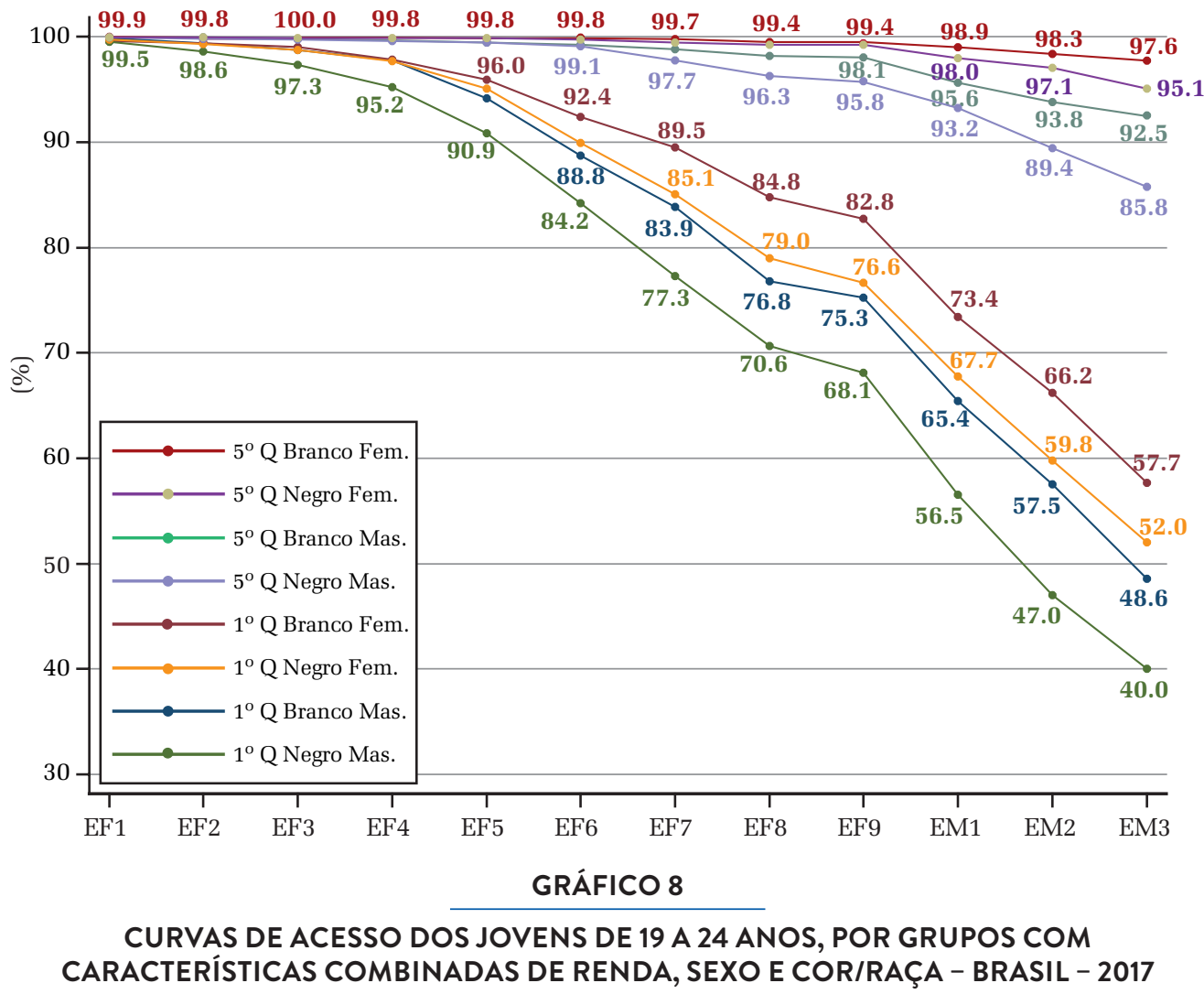

Fonte: Elaboração própria com base em dados de Pnad Contínua / IBGE (2017).

Outro aspecto que se pode inferir das curvas de acesso do Gráfico 8 é o crescimento da desigualdade intragrupos de renda. Para os $20 \%$ mais pobres, a desigualdade no acesso cresce significativamente durante a segunda etapa do ensino fundamental, principalmente entre os homens negros e as mulheres brancas, saindo de 6,1 p.p. no $5^{\circ}$ ano para 14,7 p.p. no $9^{\circ}$ ano, atingindo 17,7 p.p. no $3^{\circ}$ ano do ensino médio. A desvantagem dos homens negros está presente desde as séries iniciais do

\footnotetext{
${ }^{18}$ Os intervalos de confiança mostram não haver diferenças estatísticas no acesso aos anos escolares para esses dois grupos (não apresentado no Gráfico 8).
} 
ensino fundamental no grupo de renda mais baixo. Na transição para o ensino médio, e até o $3^{\circ}$ ano, as curvas de acesso dos grupos de renda baixa ficam praticamente paralelas, mostrando que há pouca variação na desigualdade nessa etapa. Já para os $20 \%$ mais ricos, a desigualdade intragrupo no acesso cresce durante toda a segunda etapa do ensino fundamental e, de forma mais acentuada, na transição para e durante o ensino médio, alcançando uma brecha de 11,8 p.p. no $3^{\circ}$ ano entre homens negros e mulheres brancas. Finalmente, a desigualdade entre os grupos de renda tende a aumentar dramaticamente na transição para o ensino médio e até o final da educação básica, chegando a 57,6 p.p. entre o jovem negro do primeiro quintil de renda e a mulher branca do quinto quintil de renda.

Há uma ineficiência seletiva do sistema de ensino, caracterizada principalmente pelo viés de renda e racial na formação dos grupos em condição de atraso ou exclusão escolar e, consequentemente, na restrição ao acesso integral à educação básica. A desvantagem do jovem negro de baixa renda nesse aspecto salta aos olhos. Para esse grupo não se pode falar em universalização do acesso nem mesmo no que se refere aos anos iniciais do ensino fundamental, visto que cerca de $10 \%$ dos jovens de 19 a 24 anos desse grupo sequer chegaram ao $5^{\circ}$ ano dessa etapa de ensino.

\subsection{AS CURVAS DE ACESSO DOS EVADIDOS DO SISTEMA EDUCACIONAL}

Uma utilidade analítica das curvas de acesso é ajudar a identificar em que etapa ou transição de ano escolar as crianças e jovens que não mais frequentam a escola evadiram. Isso é feito a partir da construção das curvas de acesso para a população que está fora da escola, mas que chegou a frequentá-la em algum momento no passado. O Gráfico 9 mostra as curvas de acesso dos jovens de 19 anos que, em 2017, já não frequentavam a escola, desagregando para os quintis extremos da distribuição de renda domiciliar per capita. A diferença para a curva apresentada no Gráfico 5 é que naquela está indicado o percentual dos jovens que chegaram a um determinado ano escolar da educação básica independentemente da situação de frequência à escola desse jovem em 2017. Nas curvas do Gráfico 9, estima-se esse mesmo percentual apenas para os jovens que já deixaram a escola, portanto é possível avaliar que percentual foi deixando a escola a cada transição de ano ou etapa escolar.

A análise da curva de acesso dos $20 \%$ mais pobres que não frequentavam a escola em 2017 (Gráfico 9) permite dizer que entre o $1^{\circ}$ e o $9^{\circ}$ ano do ensino fundamental houve uma redução no acesso escolar de 25,4 p.p., dos quais 21,3 p.p. (aproximadamente 84\% do total) ocorreu na transição para ou durante a segunda etapa do ensino fundamental. É durante essa etapa que também ocorre o maior aumento da brecha de acesso entre os grupos de renda ( $1^{\circ}$ e $5^{\circ}$ quintis), que varia de 3,8 p.p. no $5^{\circ}$ ano para 22,0 p.p no $9^{\circ}$ ano (+18.2 p.p.). Conseguiram chegar com aprovação ao final 
do ensino fundamental $96,5 \%$ dos jovens dos $20 \%$ mais ricos, enquanto, entre os $20 \%$ mais pobres, apenas $74,5 \%$ concluíram essa etapa com aprovação. Na transição para o ensino médio, há uma nova redução de 9,1 p.p. no acesso entre os $20 \%$ mais pobres e, durante o ensino médio, mais 14,4 p.p. são reduzidos do percentual de participação desse grupo no acesso escolar. A brecha de acesso com o quintil superior aumenta durante o ensino médio, mas com menor intensidade do que ocorre durante o ensino fundamental, passando de 22,0 p.p. no $9^{\circ}$ ano para 34,8 p.p. (+12,8 p.p.) no $8^{\circ}$ ano do ensino médio. Ao todo, o "atrito" que ocorre na trajetória escolar dos jovens de famílias mais pobres se divide em uma perda de 25,4 p.p. no ensino fundamental e uma perda de 23,5 p.p. na transição para e durante o ensino médio. Portanto, a maior parte da exclusão escolar para os mais pobres ocorre durante o ensino fundamental, em particular na segunda etapa que compreende do $6^{\circ}$ ao $9^{\circ}$ ano. A análise da curva de acesso para os já excluídos da escola mostra que, entre os mais pobres, apenas metade conseguiu concluir o ensino médio, sendo que um em cada quatro sequer concluiu o ensino fundamental.

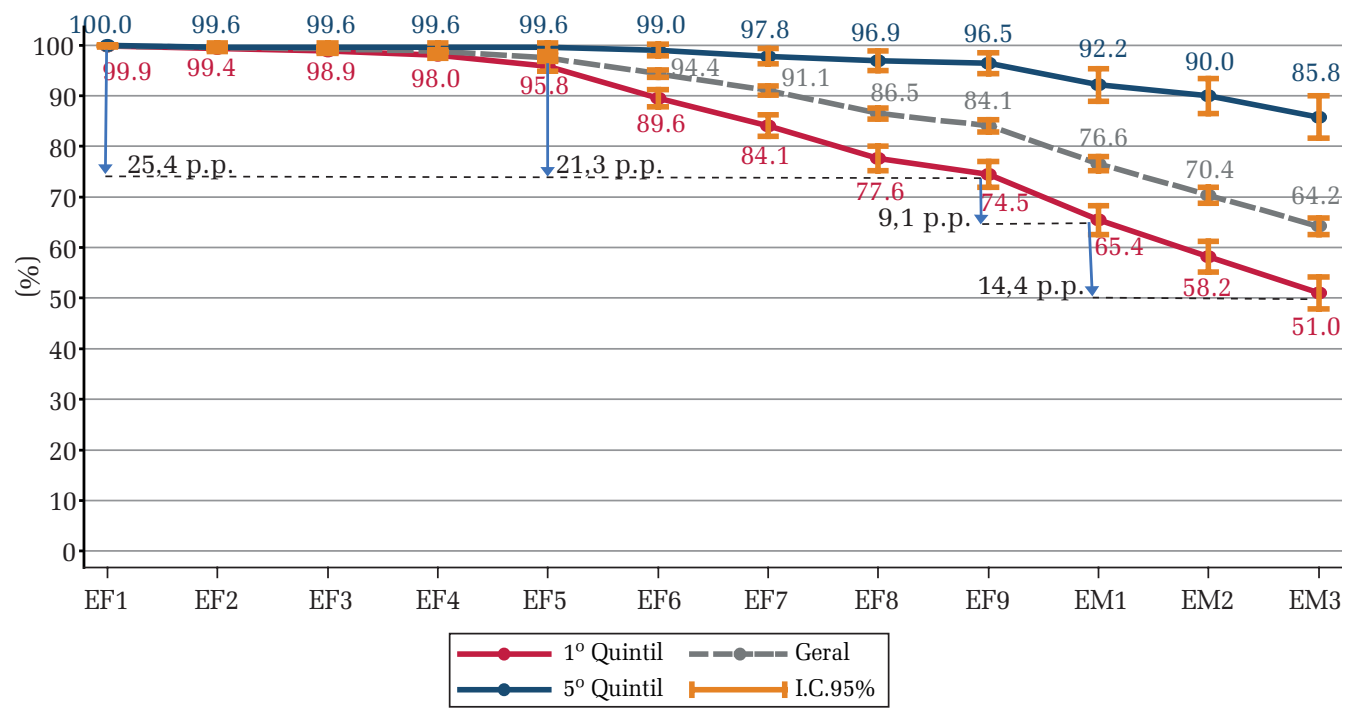

GRÁFICO 9

PERCENTUAL DA POPULAÇÃO DE 19 ANOS QUE NÃO FREQUENTA, MAS ALCANÇOU (COM APROVAÇÃO) OS ANOS ESCOLARES DA EDUCAÇÃO BÁSICA - GERAL, $1^{\circ}$ E $5^{\circ}$ QUINTIS DE RENDA DOMICILIAR PER CAPITA - BRASIL - 2017

Fonte: Elaboração própria com base em dados de Pnad Contínua / IBGE (2017).

Se considerarmos os jovens negros entre 19 e 24 anos de idade do primeiro quintil de renda que já haviam deixado a escola, o resultado no acesso é ainda mais dramático. O Gráfico A-3 (no apêndice) mostra que apenas 38,3\% deles chegaram a completar a educação básica e que praticamente um em cada três sequer chegou a concluiu o ensino fundamental. O "atrito" na trajetória escolar desse grupo é 
distintamente maior que nos demais. Entre o $5^{\circ}$ e o $9^{\circ}$ ano, há uma perda de participação escolar de 23,4 p.p., seguida de uma redução de 14,3 p.p. na passagem para o ensino médio e uma queda de mais 13,4 p.p. no acesso desse grupo entre o $1^{\circ}$ e o $3^{\circ}$ ano do ensino médio. Observa-se também que os homens estão claramente em desvantagem no acesso quando se consideram os jovens que já deixaram a escola, independente do nível de renda.

O acesso escolar no Brasil vem sendo avaliado tão somente pela frequência líquida ao ensino fundamental das crianças de 6 a 14 anos e pela frequência à escola e a taxa líquida no ensino médio dos jovens de 15 a 17 anos (Brasil. Inep, 2018). Como já discutido na literatura (Lewin, 2007, 2011; Simões, 2016), os indicadores baseados na frequência escolar, e mesmo nas taxas líquidas de matrícula, não permitem uma descrição completa do fenômeno do acesso, pois omitem a exclusão que ocorre durante a trajetória escolar de alguns grupos sociais. As curvas de acesso apresentadas nesta seção ajudam a compreender que o problema do acesso escolar no Brasil é um desafio ainda a ser superado, pois não há acesso integral de todas as crianças e jovens a todos os anos escolares da educação básica.

Na próxima seção, as curvas de acesso são analisadas para as diferentes regiões e unidades da Federação, buscando-se identificar padrões e eventuais estados que tenham avançado no desafio do acesso na perspectiva discutida neste trabalho.

\section{UM OLHAR SOBRE O ACESSO À EDUCAÇÃO BÁSICA NAS GRANDES REGIÕES E UNIDADES DA FEDERAÇÃO}

As regiões geográficas se apresentam em três níveis de acesso escolar (Gráfico 10). Isoladamente a região Sudeste apresenta a melhor curva de acesso, com $93 \%$ dos jovens de 19 anos tendo chegado ao último ano do ensino fundamental e 75\% ao último ano do ensino médio até 2017. Em seguida temos as regiões Sul e Centro-Oeste com curvas de acesso indistintas estatisticamente, com cerca de 90\% dos jovens de 19 anos alcançando o $9^{\circ}$ ano do ensino fundamental e cerca de $70 \%$ alcançando o $3^{\circ}$ ano do ensino médio. Por fim, as regiões Norte e Nordeste possuem curvas de acesso mais baixas e indistintas estatisticamente, alcançando o final do ensino fundamental aproximadamente 85\% dos jovens de 19 anos e o final do ensino médio cerca de $60 \%$ dos jovens dessas regiões. Portanto, o melhor desempenho quanto ao acesso à educação básica ocorre no Sudeste. Ainda assim, um em cada quatro jovens dessa região não havia alcançado o $3^{\circ}$ ano do ensino médio até o ano de 2017. Nas regiões Norte e Nordeste, um em cada quatro jovens não logrou sequer entrar no ensino médio. 


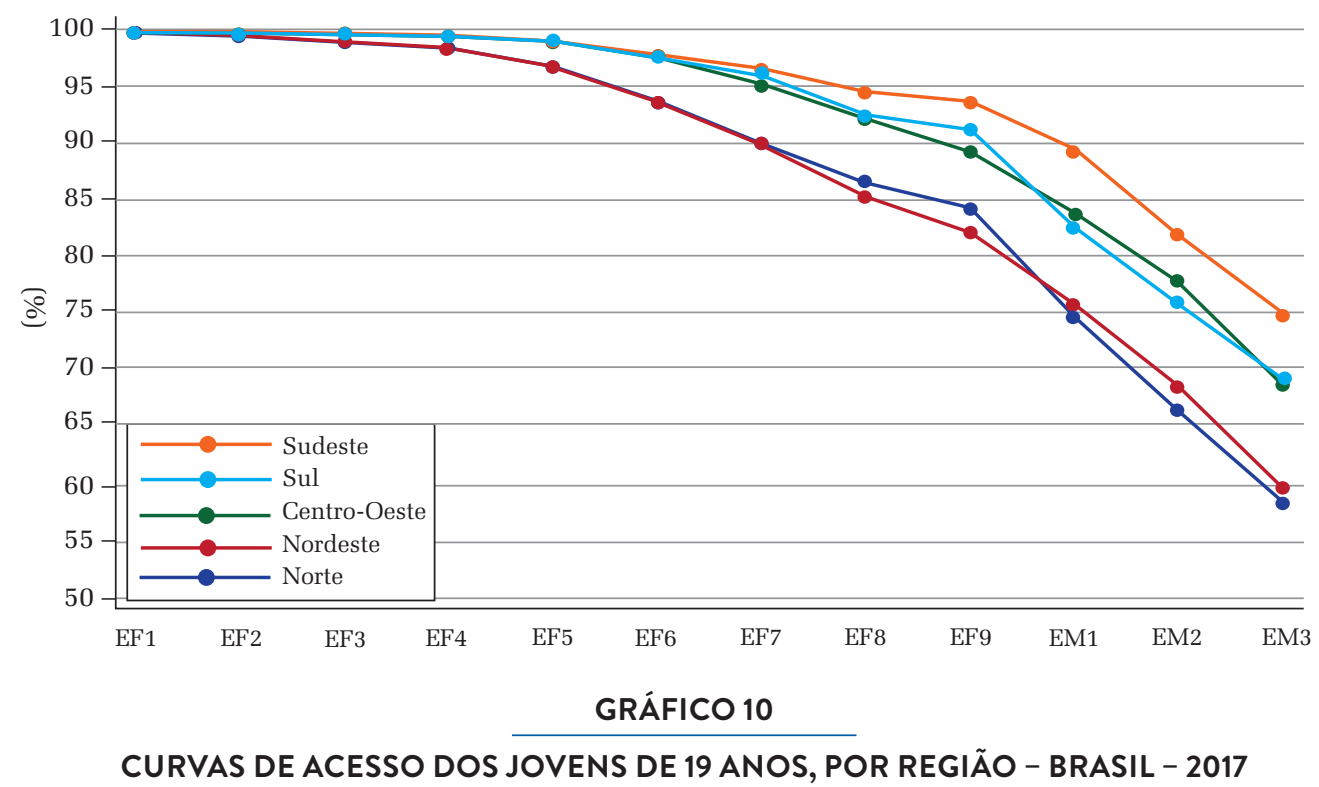

Fonte: Elaboração própria com base em dados de Pnad Contínua / IBGE (2017).

A desigualdade de acesso observada entre regiões também ocorre entre estados de uma mesma região. Os Gráficos 11 a 15 abaixo mostram as curvas de acesso dos jovens de 19 anos estimadas para o ano de 2017 nos estados em cada região. Observa-se um padrão de desigualdade no acesso que surge a partir do $6^{\circ}$ ano do ensino fundamental e cresce durante a segunda etapa desse nível de ensino. Outro padrão que se observa é a mudança da inclinação das curvas de acesso entre a primeira etapa do ensino fundamental e o ensino médio, caracterizando o maior grau de "atrito" ou perda de crianças e jovens à medida que se avança de uma etapa para outra. Em particular, nota-se uma forte mudança da inclinação das curvas de acesso a partir do $1^{\circ}$ ano do ensino médio, o que mostra ser ainda muito difícil no Brasil que um jovem chegue ao ensino médio no tempo esperado, em especial em alguns estados do Norte e Nordeste.

Na região Centro-Oeste (Gráfico 11), os estados não se diferenciam quanto ao acesso até o $5^{\circ}$ ano do ensino fundamental. Já na segunda etapa do ensino fundamental, a desigualdade de acesso cresce entre os estados, alcançando uma brecha de 8 p.p. no $9^{\circ}$ ano entre Mato Grosso (MT) e Mato Grosso do Sul (MS) e de 10 p.p. no $3^{\circ}$ ano entre MS e o Distrito Federal (DF).

O Mato Grosso do Sul (MS) apresenta o pior desempenho no acesso ao mesmo tempo em que a maior queda de participação do jovem de 19 anos entre o término do ensino fundamental e o ingresso no ensino médio (10 p.p.). Já o Mato Grosso (MT) apresenta a melhor curva de acesso até o $9^{\circ}$ ano. Contudo, o MT é o estado da região que apresenta a maior queda no acesso entre o $9^{\circ}$ ano do ensino fundamental e o $3^{\circ}$ 
ano do ensino médio (-29 p.p.), ficando abaixo de Goiás (GO) e do Distrito Federal. O DF apresenta a melhor curva de acesso à educação básica da região para os jovens de 19 anos, com 73\% deles tendo alcançado o $3^{\circ}$ ano do ensino médio até 2017 , muito semelhante à curva de acesso de GO.

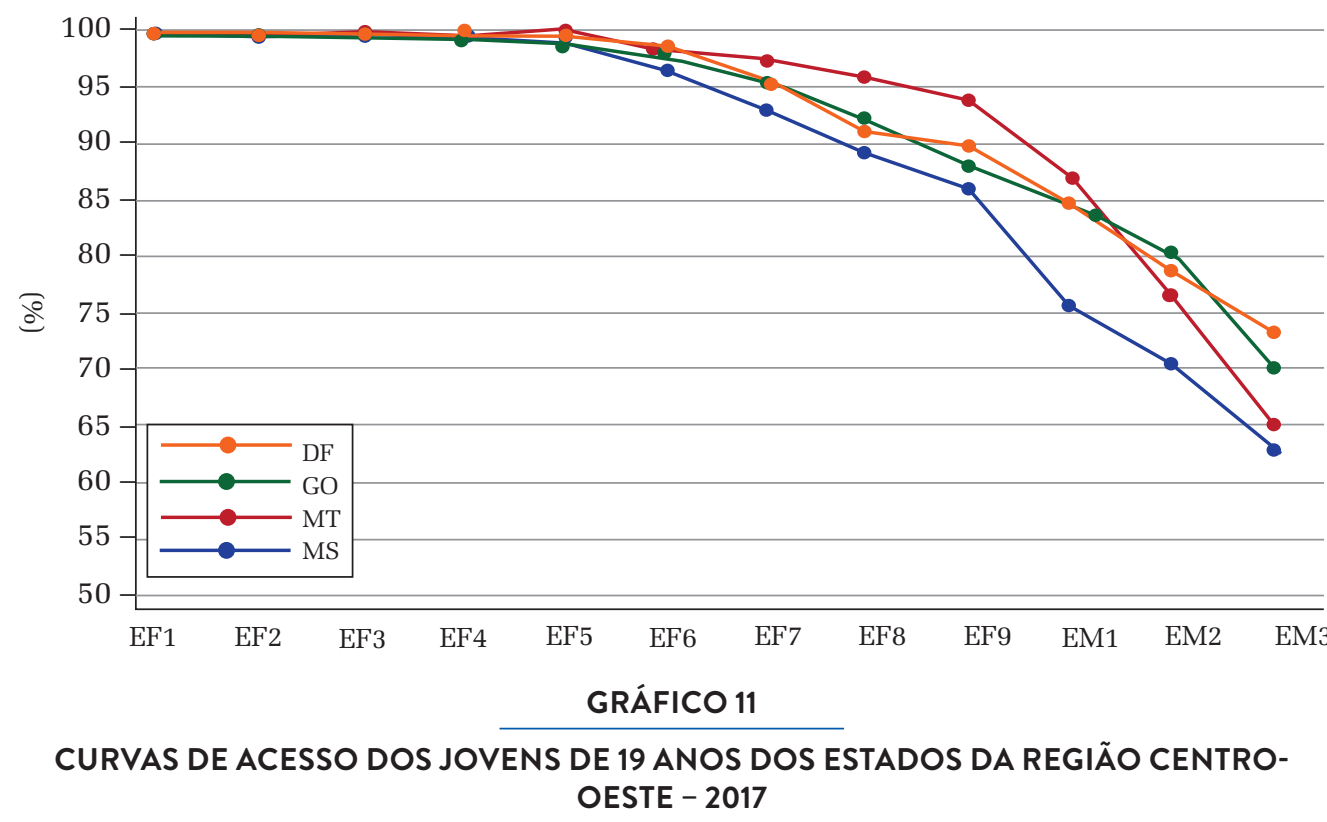

Fonte: Elaboração própria com base em dados de Pnad Contínua / IBGE (2017).

Em geral, "quebras" acentuadas nas curvas de acesso, como as observadas no caso de MT e MS entre o $9^{\circ}$ ano e o $1^{\circ}$ ano do ensino médio, significam a presença de um novo fator de interrupção da trajetória escolar que se soma ao "atrito" causado por fatores cumulativos presentes em toda a trajetória escolar como a reprovação e a repetência. Essas "quebras" sugerem a presença de um componente novo ligado ou à oferta ou à demanda que dificulta o ingresso na etapa seguinte. No caso da oferta, pode significar insuficiência de vagas no ano ou etapa seguinte, má distribuição de vagas no território em relação à população estudantil para aquele ano ou etapa, dificuldades com transporte escolar etc. Já do lado da demanda, pode ocorrer atração dos jovens para o mercado de trabalho, evasão devido ao atingimento da maioridade associado à pressão familiar por geração de renda, menores incentivos à continuidade dos estudos devido ao padrão de oferta de postos de trabalho na região etc. Quebras acentuadas também são observadas na maioria dos estados das demais regiões entre o ensino fundamental e o ensino médio sugerindo existir uma barreira para que parte dos jovens chegue a ingressar nessa etapa.

Na região Sudeste (Gráfico 12), São Paulo é o único estado que se destaca quanto à curva de acesso, tendo 96\% dos jovens de 19 anos alcançado o $9^{\circ}$ ano do ensino 
fundamental, 93\% chegado a ingressar no ensino médio e $80 \%$ conseguido atingir o $3^{\circ}$ ano do ensino médio até 2017. Esse é o melhor resultado do país, embora ainda não se possa falar de universalização do acesso à educação básica, mesmo neste que é o estado mais rico da federação. Um em cada cinco jovens em São Paulo serão excluídos da escola em sua trajetória antes de concluir a escola básica ou estarão em atraso escolar e, portanto, sob risco de exclusão antes de concluírem. Os demais estados do Sudeste apresentam curvas de acesso muito semelhantes, com cerca de 90\% chegando ao final do ensino fundamental, mas com tendência de exclusão ou atraso a partir da transição para o ensino médio. Cerca de 70\% dos jovens de Minas Gerais (MG), Rio de Janeiro (RJ) e Espírito Santo (ES) alcançaram o $3^{\circ}$ ano do ensino médio até 2017.

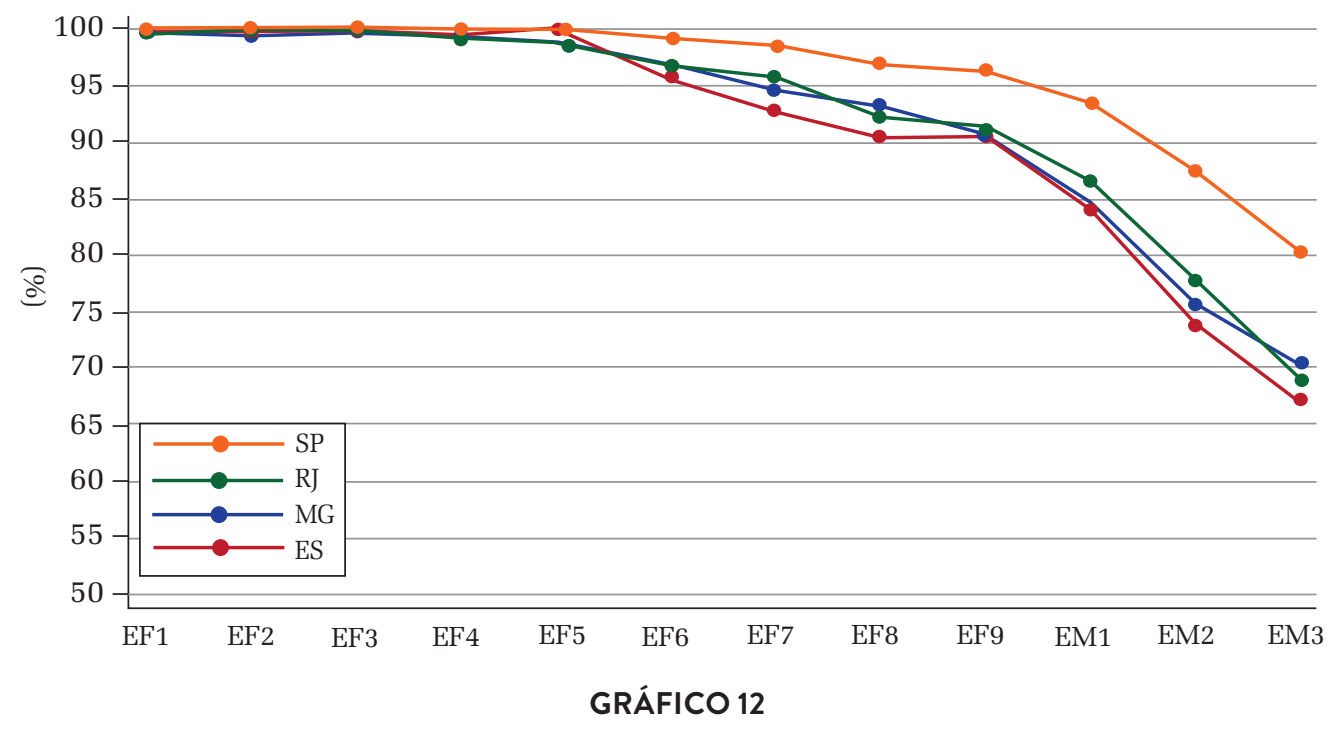

CURVAS DE ACESSO DOS JOVENS DE 19 ANOS DOS ESTADOS DA REGIÃO SUDESTE - 2017

Fonte: Elaboração própria com base em dados de Pnad Contínua / IBGE (2017).

Na região Sul (Gráfico 13), o estado de Santa Catarina (SC) se destaca no acesso à educação básica, com 96\% dos jovens de 19 anos tendo alcançado, até 2017, o $9^{\circ}$ ano do ensino fundamental, mesmo índice de São Paulo. Ao $3^{\circ}$ ano do ensino médio haviam chegado 73\% dos jovens. Paraná (PR) e Rio Grande do Sul (RS) apresentam curvas de acesso muito próximas, se distanciando de SC a partir do $6^{\circ}$ ano. Os três estados apresentam forte queda no acesso à educação básica na transição para o ensino médio, com quedas de 8,2 p.p. no PR e SC e 10 p.p. no RS. A queda no acesso é contínua no ensino médio, havendo perdas expressivas de 14,6 p.p. em SC, 19,7 p.p. no PR e 23,8 p.p. no RS entre o ingresso no $1^{\circ}$ e $3^{\circ}$ ano desta etapa. Como ocorre em todas as regiões, a brecha de acesso entre os estados nasce e é ampliada fortemente na segunda etapa do ensino fundamental. 


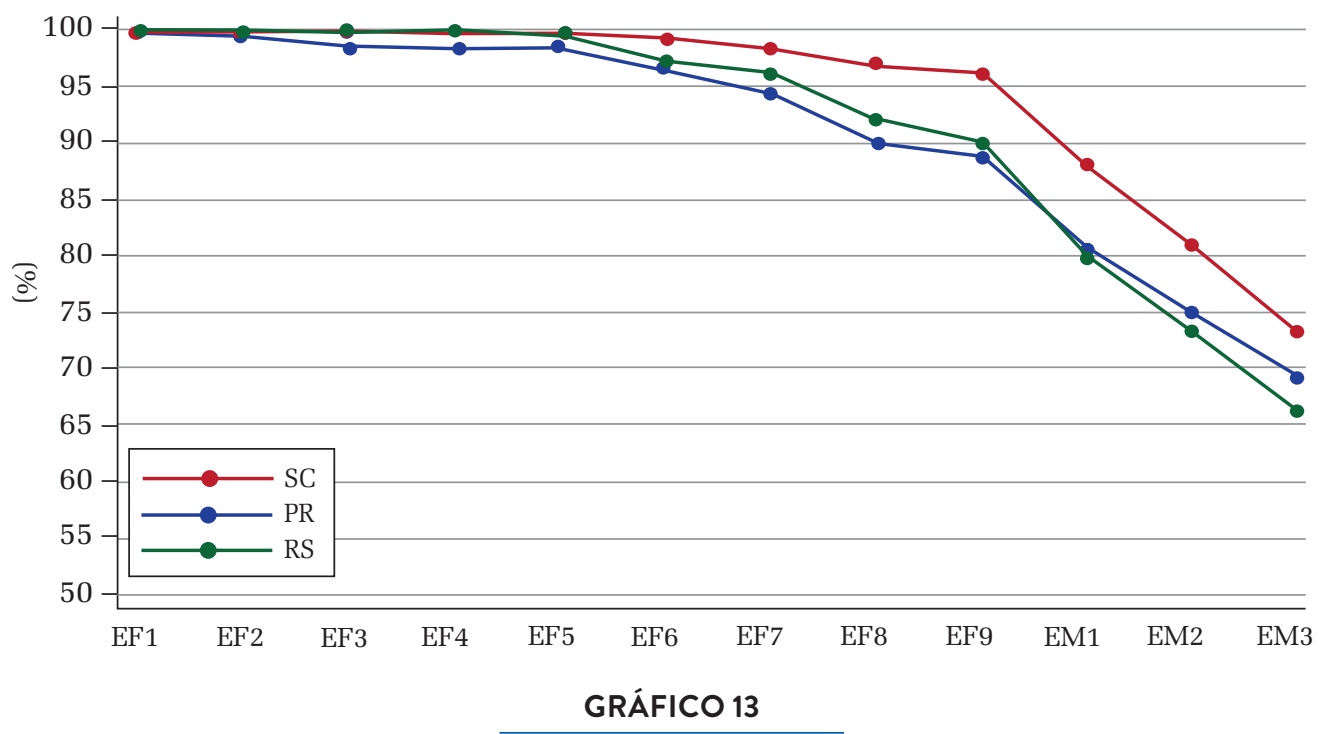

CURVAS DE ACESSO DOS JOVENS DE 19 ANOS DOS ESTADOS DA REGIÃO SUL -2017

Fonte: Elaboração própria com base em dados de Pnad Contínua / IBGE (2017).

Na região Nordeste (Gráfico 14), o estado do Ceará (CE) apresenta a melhor curva de acesso, seguido do Maranhão (MA) e de Pernambuco (PE). No CE, 86\% dos jovens de 19 anos chegaram ao $9^{\circ}$ ano do ensino fundamental e $66 \%$ ao $3^{\circ}$ ano, ou seja, o "atrito" na trajetória da educação básica no CE atinge um em cada três jovens. Os piores desempenhos na região são observados em Sergipe (SE), Alagoas (AL) e Piauí (PI). Em Sergipe, 79\% desses jovens chegaram ao final do ensino fundamental e apenas cerca de $50 \%$ alcançaram o $3^{\circ}$ ano do ensino médio, ou seja, metade dos jovens em Sergipe são excluídos do sistema educacional antes de concluírem a educação básica ou se encontram em atraso escolar. O baixo acesso verificado em Sergipe também ocorre em Alagoas e no Piaú́.

Por último, na região Norte (Gráfico 15), o Tocantins (TO), o Acre (AC) e Roraima (RR) apresentam as melhores curvas de acesso à educação básica para jovens que, em 2017, tinham completado 19 anos. O Pará (PA) apresenta nítido distanciamento dos demais estados já partir do $6^{\circ}$ ano, apresentando a pior curva de acesso da região, principalmente na segunda etapa do ensino fundamental. Os estados de Rondônia (RO), Amapá (AP) e Amazonas (AM) apresentam forte queda no acesso a partir do $1^{\circ}$ ano do ensino médio. A região Norte é a que apresenta a maior desigualdade intrarregional entre as cinco regiões do país, com uma brecha de 19 p.p. entre o PA e o TO no acesso dos jovens de 19 anos ao $3^{\circ}$ ano do ensino médio. 


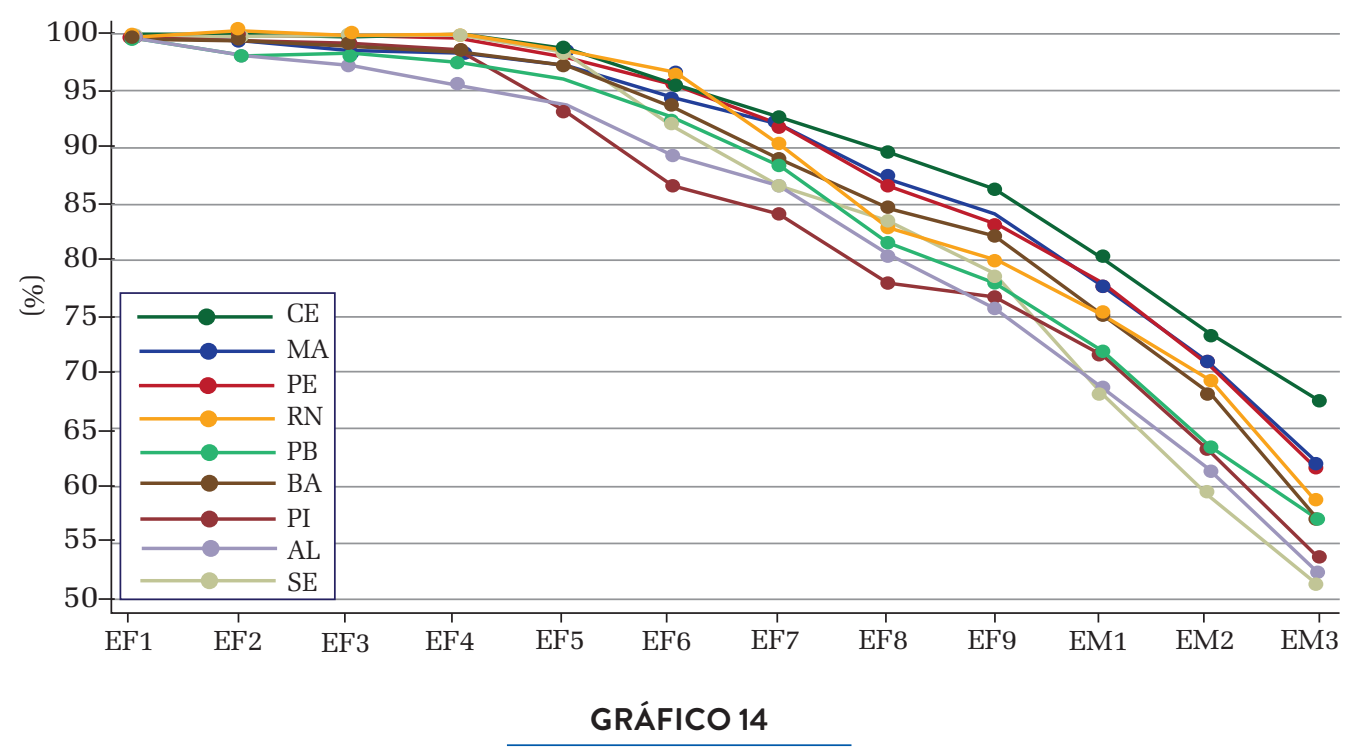

CURVAS DE ACESSO DOS JOVENS DE 19 ANOS DOS ESTADOS

DA REGIÃO NORDESTE - 2017

Fonte: Elaboração própria com base em dados de Pnad Contínua / IBGE (2017).

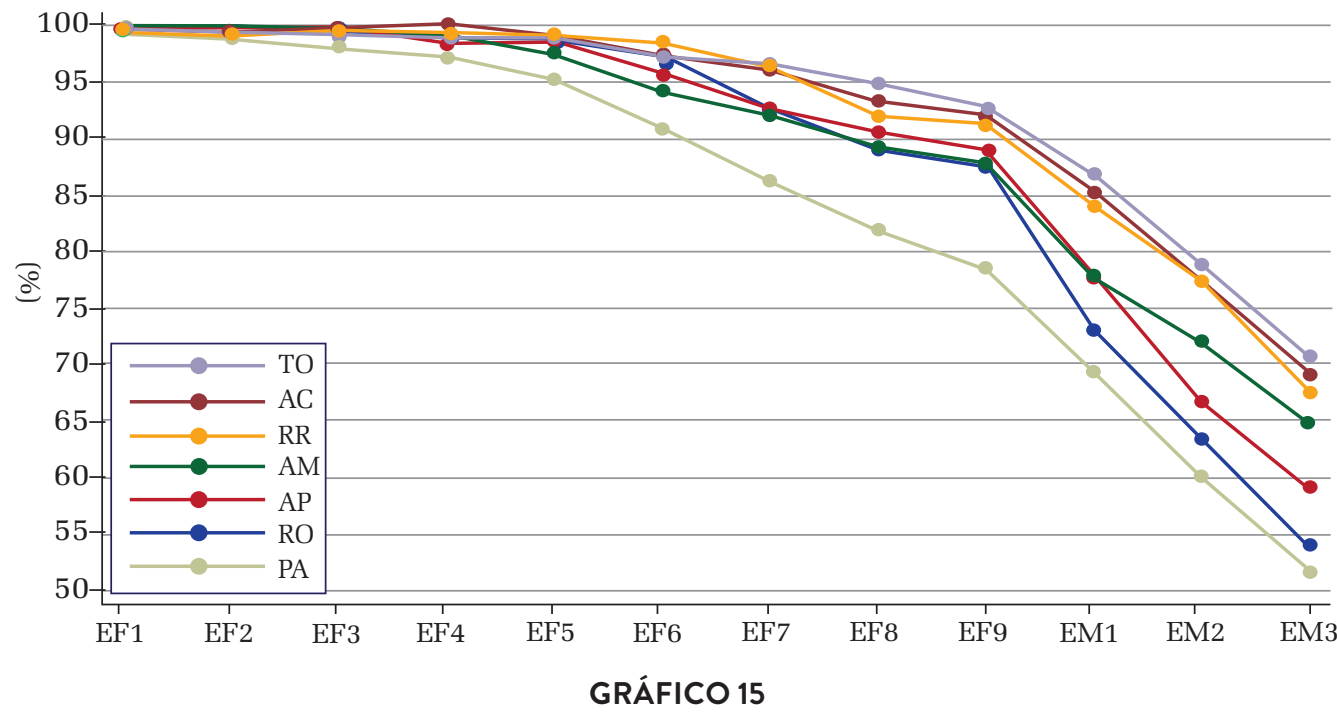

CURVAS DE ACESSO DOS JOVENS DE 19 ANOS DOS ESTADOS

DA REGIÃO NORTE - 2017

Fonte: Elaboração própria com base em dados de Pnad Contínua / IBGE (2017). 


\section{UM OLHAR SOBRE A DESIGUALDADE DE ACESSO À EDUCAÇÃO BÁSICA DEVIDO À RENDA NAS GRANDES REGIÕES E UNIDADES DA FEDERAÇÃO}

\subsection{A BRECHA DE ACESSO NAS GRANDES REGIÕES}

Anteriormente, na Figura 1, foi visto que a renda domiciliar per capita responde pela maior desigualdade observada na curva de acesso dos jovens de 19 anos entre as caraterísticas examinadas. Essa desigualdade difere entre regióes e estados do Brasil. A Figura 2 mostra a curva de acesso desses jovens desagregada para os 20\% mais pobres e os $20 \%$ mais ricos da população para as cinco grandes regiões. O nível do acesso aos anos escolares da educação básica difere bastante entre os mais ricos e mais pobres em cada região.
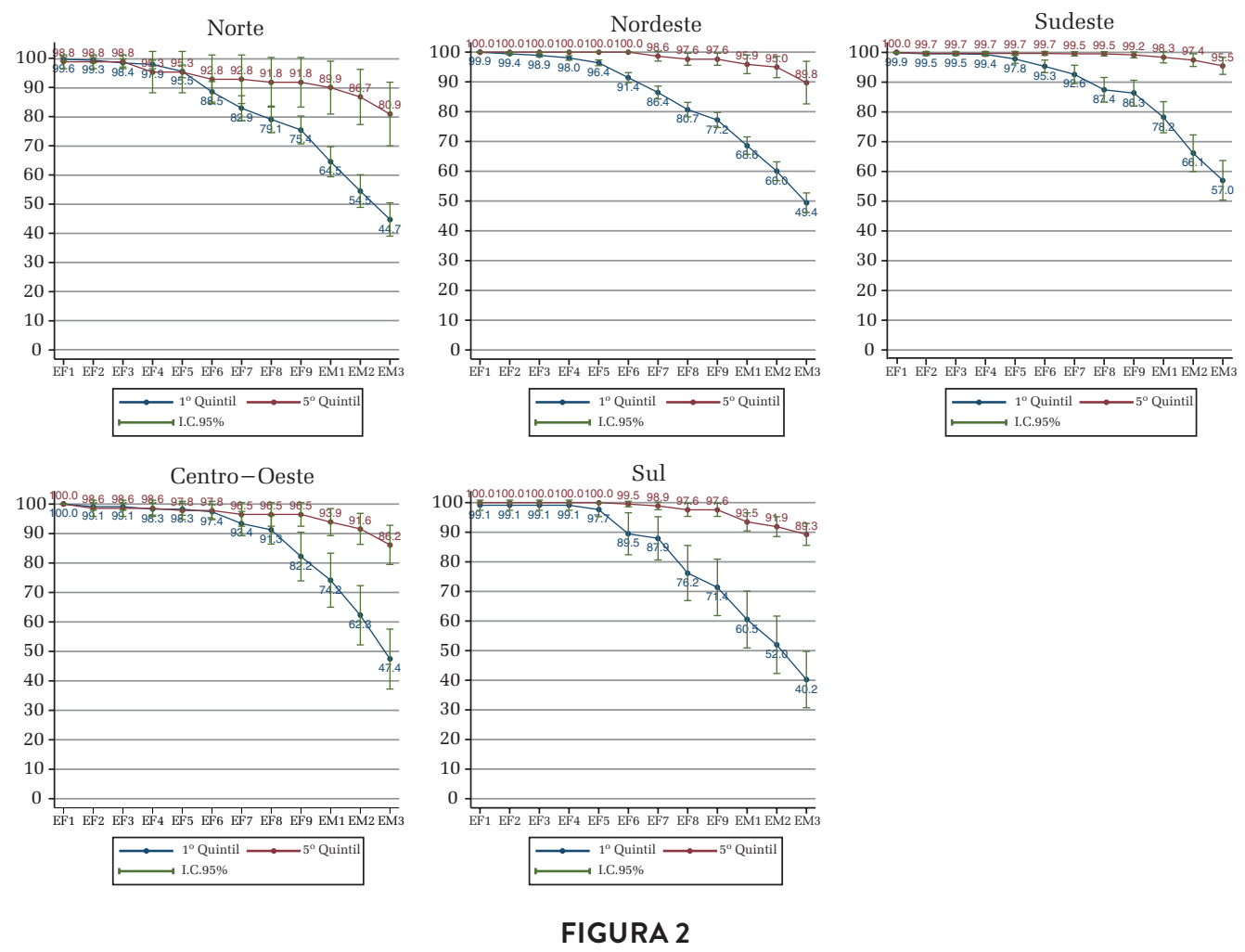
Se, por um lado, não há desigualdade entre os quintis de renda até o $5^{\circ}$ ano do ensino fundamental, com exceção do Nordeste (3,6 p.p.), por outro, a partir do $6^{\circ}$ ano, observa-se o crescimento da brecha de acesso entre os jovens de 19 anos dos quintis inferior e superior em todas as regiões, crescimento esse que se acentua na transição para e durante o ensino médio.

A análise da variação da desigualdade de acesso entre os quintis extremos da distribuição de renda domiciliar per capita nas diferentes regiões e etapas da educação básica permite identificar onde e quando ela mais cresce. Durante os anos finais do ensino fundamental, essa desigualdade cresce cerca de 3 p.p. por ano escolar no Sudeste, cerca de 4 p.p. por ano escolar nas regiões Norte, Nordeste e Centro-Oeste e 6 p.p. na região Sul (Tabela 1). Mas é na transição para e durante o ensino médio que a desigualdade de acesso mais cresce em todas as regiões entre o primeiro e o quinto quintis de renda domiciliar per capita. Entre o $9^{\circ}$ ano e o $3^{\circ}$ ano do ensino médio, a desigualdade cresce cerca de 7 p.p. por ano escolar no Norte e Nordeste, 8 p.p. no Centro-Oeste e Sul, e 9 p.p. no Sudeste.

TABELA 1

VARIAÇÃO DA DESIGUALDADE NO ACESSO À EDUCAÇÃO BÁSICA POR ANO ESCOLAR ENTRE OS JOVENS DE 19 ANOS PERTENCENTES AOS 20\% MAIS POBRES E AOS 20\% MAIS RICOS, NAS DIFERENTES ETAPAS DA EDUCAÇÃO BÁSICA, POR GRANDE REGIÃO - 2017

\begin{tabular}{|l|c|c|c|c|}
\hline \multicolumn{1}{|c|}{ Região } & $\begin{array}{c}\text { Variação na } \\
\text { desigualdade por } \\
\text { ano escolar EF - } \\
\text { anos iniciais }\end{array}$ & $\begin{array}{c}\text { Variação na } \\
\text { desigualdade por } \\
\text { ano escolar EF - } \\
\text { anos finais }\end{array}$ & $\begin{array}{c}\text { Variação na } \\
\text { desigualdade por } \\
\text { ano escolar EF }\end{array}$ & $\begin{array}{c}\text { Variação na } \\
\text { desigualdade por } \\
\text { ano escolar EM }\end{array}$ \\
\hline Norte & 0,0 & 4,2 & 1,8 & 6,6 \\
\hline Nordeste & 0,7 & 4,2 & 2,3 & 6,7 \\
\hline Centro-Oeste & $-0,1$ & 3,7 & 1,6 & 8,2 \\
\hline Sudeste & 0,4 & 2,8 & 1,4 & 8,5 \\
\hline Sul & 0,5 & 6,0 & 2,9 & 7,6 \\
\hline
\end{tabular}

Fonte: Elaboração própria com base em dados de Pnad Contínua / IBGE (2017).

A região Sudeste, que apresenta o menor crescimento da desigualdade no acesso durante os anos finais do ensino fundamental, vai apresentar o maior crescimento da desigualdade no acesso na transição para e durante o ensino médio. Movimento muito semelhante ocorre com a região Centro-Oeste, que apresenta o segundo menor crescimento da desigualdade durante os anos finais do ensino fundamental, seguido do segundo maior crescimento da desigualdade entre o $9^{\circ}$ ano e o $3^{\circ}$ ano do ensino fundamental.

A região Sul é a que apresenta a maior desigualdade de acesso devido à renda, alcançando uma brecha de 49 p.p. entre o primeiro e o quinto quintis de renda no $3^{\circ}$ ano do ensino médio. Essa desigualdade cresce cerca de quatro vezes na passagem do $5^{\circ}$ para o $6^{\circ}$ ano do ensino fundamental e dobra na passagem do $7^{\circ}$ para o $8^{\circ}$ ano 
nessa região. Em comparação com as demais regiões, o Sul tem a maior desigualdade de acesso para todos os anos escolares a partir do $8^{\circ}$ ano, se destacando das demais regiões, como pode ser visto no Gráfico 16. Em consequência, dos jovens de 19 anos das famílias pertencentes aos $20 \%$ mais pobres da população da região Sul, somente $40 \%$ haviam alcançado o $3^{\circ}$ ano do ensino médio até 2017 , enquanto cerca de $90 \%$ dos que vivem nas famílias pertencentes aos $20 \%$ mais ricos conseguiram chegar lá.

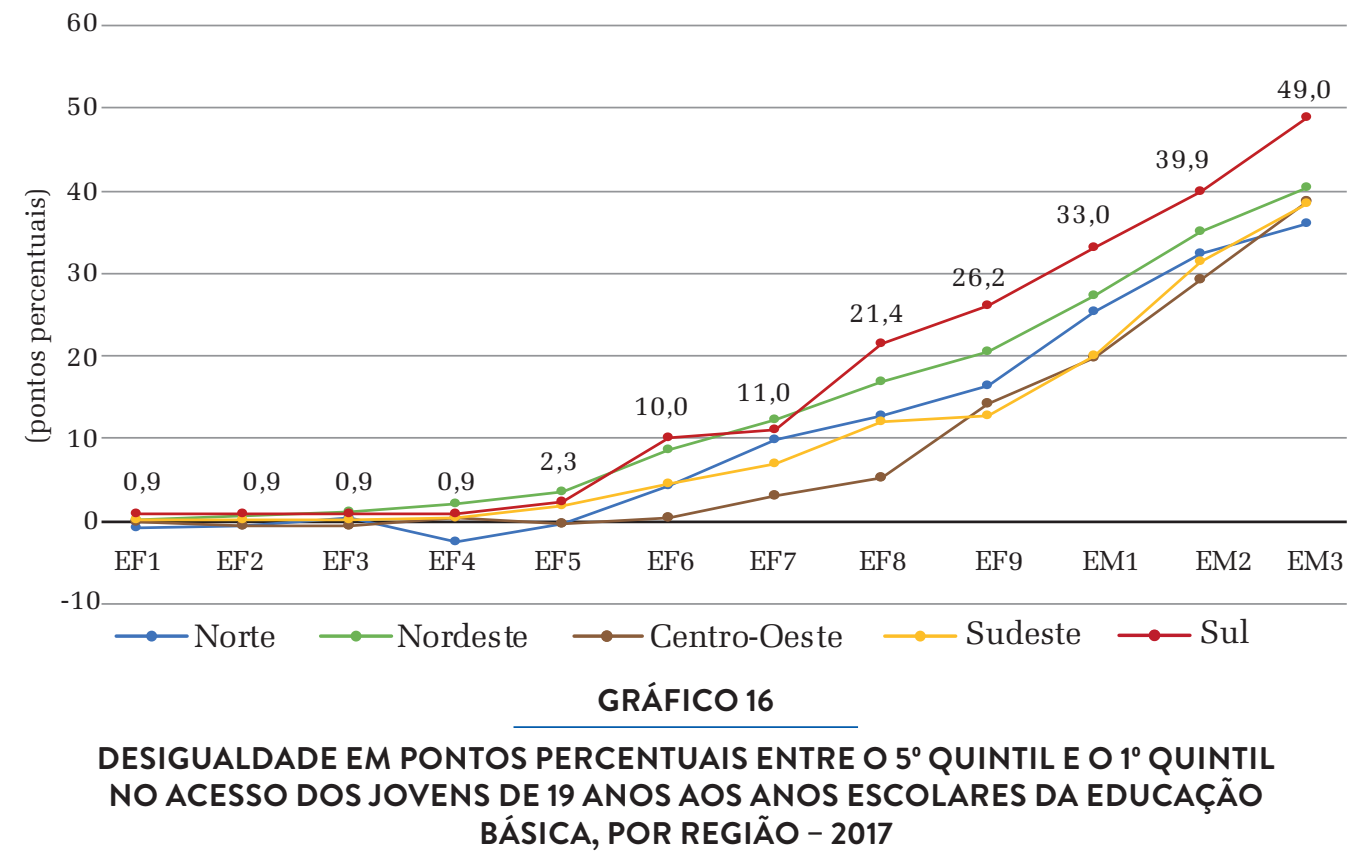

Fonte: Elaboração própria com base em dados de Pnad Contínua / IBGE (2017).

As regiões Nordeste e Norte vêm em seguida na escala da desigualdade de acesso e as regiões Sudeste e Centro-Oeste são as que apresentam menor desigualdade, estando esta última em vantagem no que tange às séries finais do ensino fundamental até o $8^{\circ}$ ano.

\subsection{A BRECHA DE ACESSO NAS UNIDADES DA FEDERAÇÃO}

Nesta seção, são apresentadas as curvas de acesso para a população de 19 a $24 \operatorname{anos}^{19}$ para os $20 \%$ mais pobres e os $20 \%$ mais ricos dos estados de cada região. Embora em todos os estados se observe grande desigualdade de acesso devido à renda, há diferenças importantes.

Na região Sudeste (Figura 3), o estado de São Paulo se destaca com a menor desigualdade de acesso entre os $20 \%$ mais pobres e os $20 \%$ mais ricos, sendo também

${ }^{19}$ O uso do grupo de 19 a 24 anos nas estimativas objetiva reduzir o erro amostral. 
o estado que apresenta a menor desigualdade de acesso de todo o país. A diferença entre esses dois grupos de renda é de 1 p.p. no $5^{\circ}$ ano, 11 p.p. no $9^{\circ}$ ano e 35 p.p. no $3^{\circ}$ ano do ensino médio. Os mais pobres entre os jovens de 19 a 24 anos têm mais chances de chegar ao final da escola básica em São Paulo, onde 60\% haviam alcançado o $3^{\circ}$ ano do ensino médio até 2017, o maior índice do país. Ainda assim, um jovem nascido em família do quinto quintil de renda domiciliar per capita tem 1,6 vezes mais chance de chegar ao final da educação básica do que um nascido no primeiro quintil. É na transição para o ensino médio e durante essa etapa que mais cresce a desigualdade de acesso entre os dois grupos em São Paulo e nos demais estados da região.
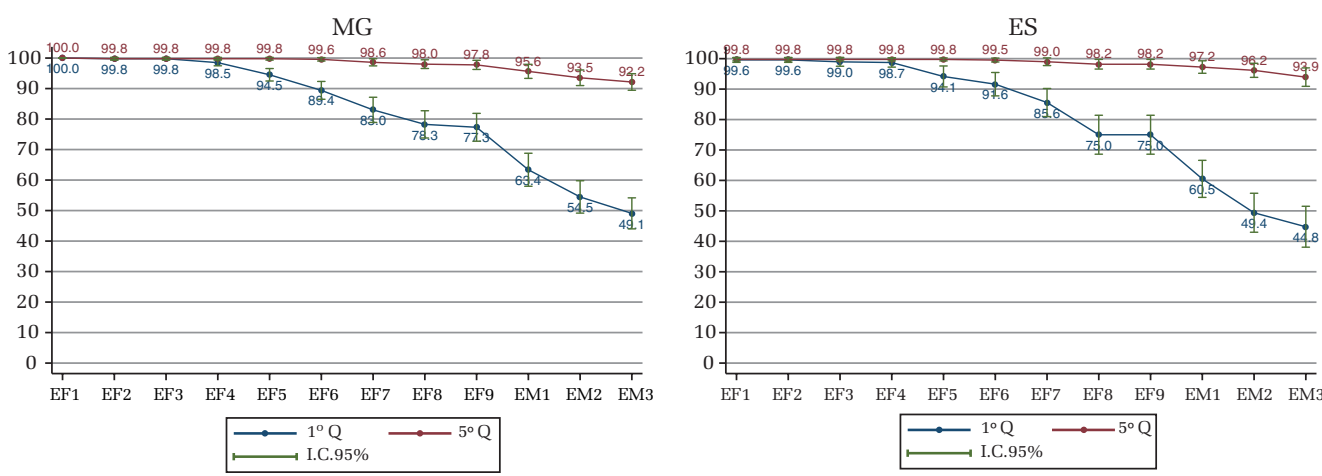

RJ
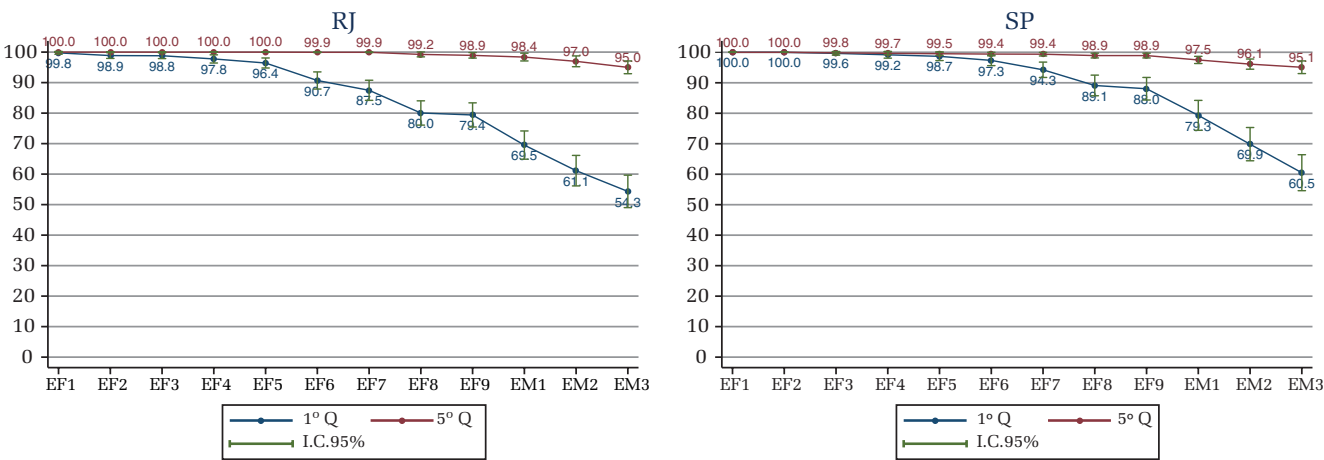

FIGURA 3

\section{CURVAS DE ACESSO DA POPULAÇÃO DE 19 A 24 ANOS, SEGUNDO O QUINTIL DE RENDA DOMICILIAR PER CAPITA, POR UNIDADE DA FEDERAÇÃO - REGIÃO SUDESTE - 2017}

Fonte: Elaboração própria com base em dados de Pnad Contínua / IBGE (2017).

O Gráfico 17 mostra a evolução da desigualdade de acesso entre os quintis extremos de renda ao longo dos anos escolares da educação básica para os estados do Sudeste. O Espírito Santo é o estado onde a desigualdade de acesso mais cresce ao longo da educação básica, alcançando 49 p.p. ao final do ensino médio. É também o estado da região Sudeste com o menor acesso dos mais pobres aos anos finais de cada etapa da educação básica, com $45 \%$ apenas chegando ao $3^{\circ}$ ano do ensino médio. O 
Rio de Janeiro e Minas Gerais têm curvas de acesso desagregadas por renda muito próximas (Figura 3), mas com vantagem do Rio de Janeiro no acesso dos mais pobres (segundo melhor da região). A evolução da desigualdade ao longo dos anos escolares fica em patamares muito próximos nesses dois estados (Gráfico 17).

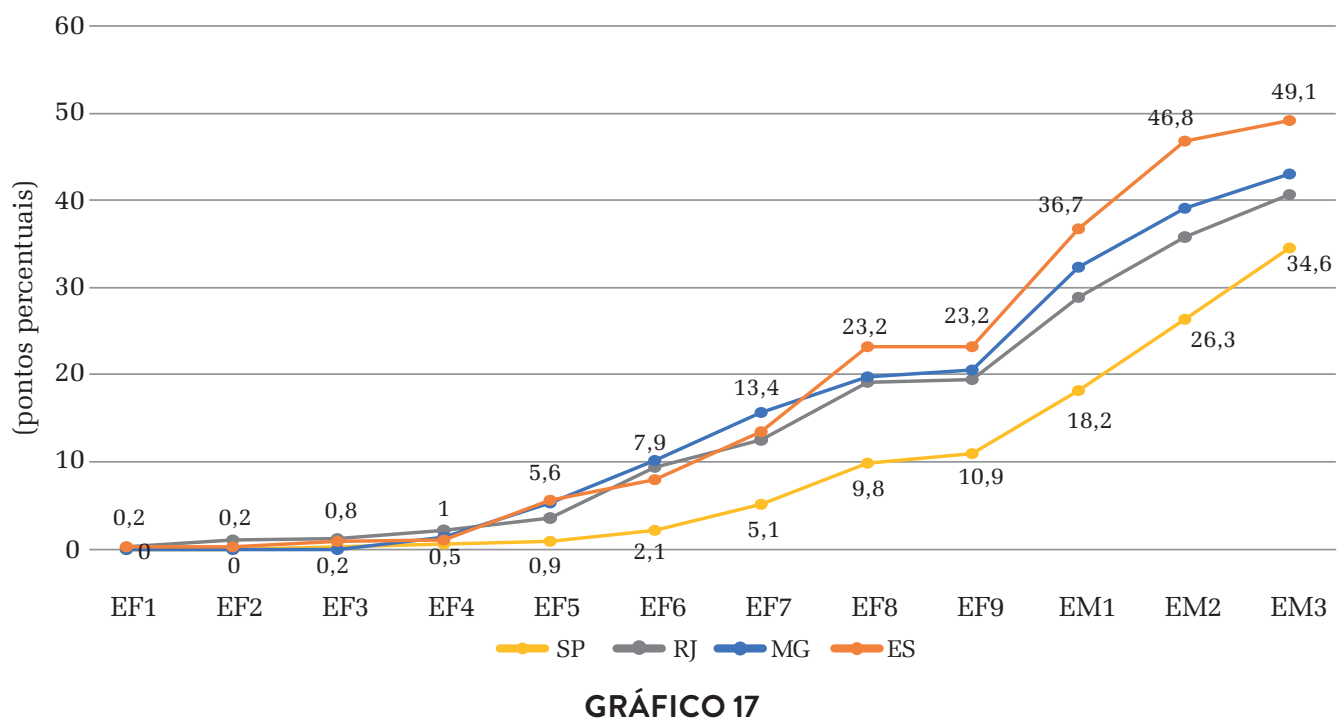

EVOLUÇÃO DA DESIGUALDADE EM PONTOS PERCENTUAIS ENTRE OS JOVENS DE 19 A 24 ANOS DOS 20\% MAIS POBRES E DOS 20\% MAIS RICOS NO ACESSO AO LONGO DOS ANOS ESCOLARES, POR UNIDADE DA FEDERAÇÃO - SUDESTE - 2017

Fonte: Elaboração própria com base em dados de Pnad Contínua / IBGE (2017).

As curvas de acesso dos estados do Nordeste são apresentadas na Figura 4. Alagoas é o estado do Nordeste e do Brasil com a maior desigualdade de acesso entre os mais pobres e os mais ricos, atingindo brechas de 9 p.p. no $5^{\circ}$ ano, 37 p.p. no $9^{\circ}$ ano e 58 p.p. no $3^{\circ}$ ano do ensino médio (Gráfico 18). Apenas 39\% dos jovens de 19 a 24 anos dos $20 \%$ mais pobres em Alagoas alcançaram o $3^{\circ}$ ano do ensino médio até $2017^{20}$. É em Alagoas também que os $20 \%$ mais ricos entre os jovens alcançaram o maior percentual de acesso ao $3^{\circ}$ ano (97\%) no Nordeste e no Brasil. Já o Ceará apresenta a melhor curva de acesso do Nordeste para os jovens de 19 anos, como visto anteriormente (Gráfico 14), e também o melhor acesso no Nordeste para os mais pobres de 19 a 24 anos, com 79\% alcançando o $9^{\circ}$ ano, 66\% ingressando no ensino médio e $51 \%$ chegando ao $3^{\circ}$ ano do ensino médio até o ano de 2017.

A evolução da desigualdade de acesso entre os quintis extremos da distribuição de renda ao longo da educação básica é menor também no Ceará, em especial na

\footnotetext{
${ }^{20}$ Outros três estados vão apresentar índice de acesso ao $3^{\circ}$ ano mais baixo que Alagoas para os $20 \%$ mais pobres. São eles: Rio Grande do Sul (34,5\%), Paraná (36,7\%) e Mato Grosso do Sul (38,7\%).
} 
segunda etapa do ensino fundamental, em que o estado se distancia dos demais da região (Gráfico 18). Mas, na transição para o ensino médio, há um aumento significativo na brecha de acesso entre os $20 \%$ mais pobres e os $20 \%$ mais ricos, saltando de 20 p.p. para 31 p.p., reposicionando o estado mais próximo dos demais em termos da desigualdade de acesso devido à renda, mas ainda assim com a menor desigualdade.
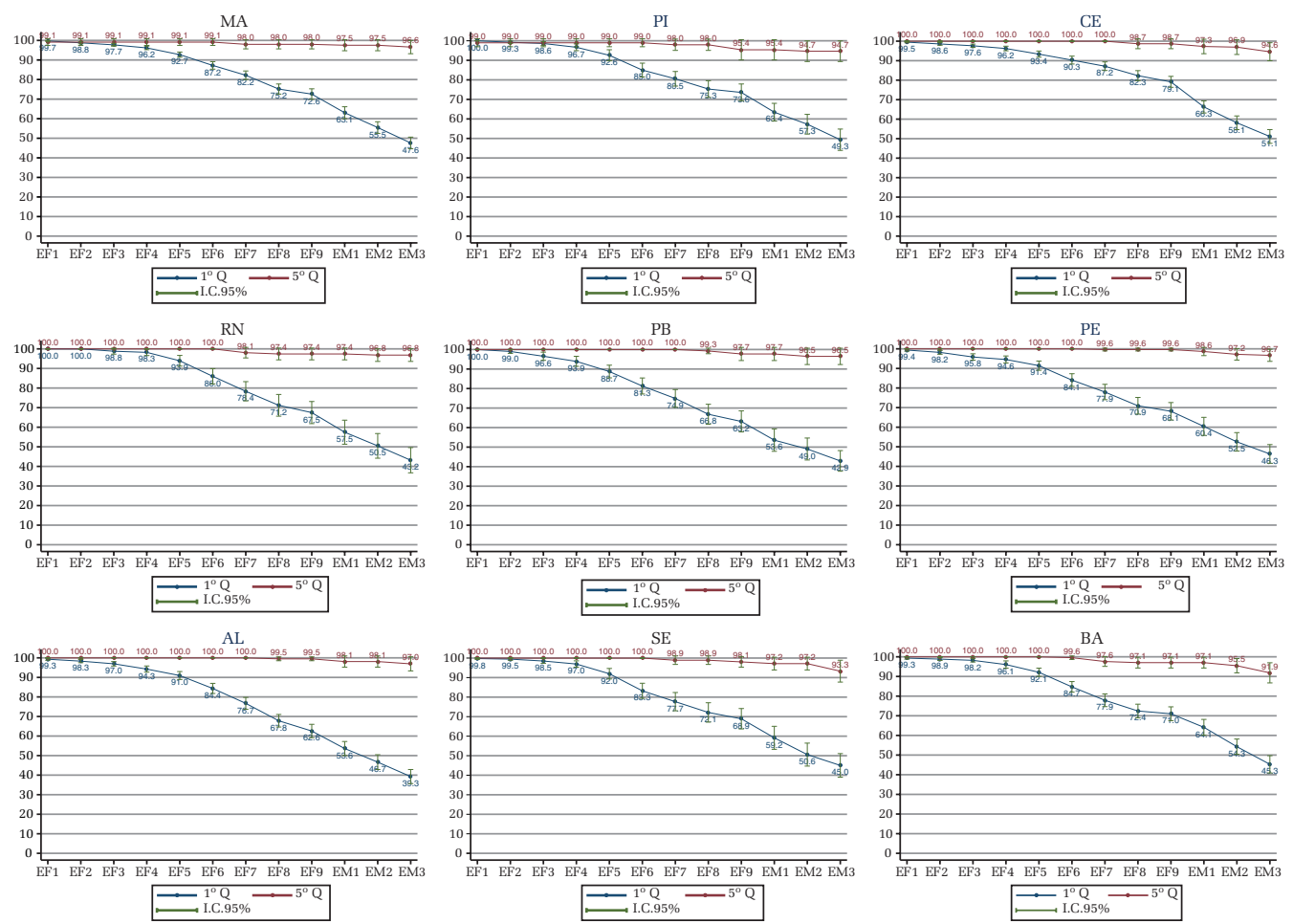

\section{FIGURA 4}

\section{CURVAS DE ACESSO DA POPULAÇÃO DE 19 A 24 ANOS, SEGUNDO O QUINTIL DE RENDA DOMICILIAR PER CAPITA, POR UNIDADE DA FEDERAÇÃO - REGIÃO NORDESTE - 2017}

Fonte: Elaboração própria com base em dados de Pnad Contínua / IBGE (2017).

Nota-se que, durante o ensino médio, a desigualdade de acesso tende a crescer nos estados do Nordeste a taxas mais próximas do que durante a segunda etapa do ensino fundamental, quando há nítida diferença no crescimento da desigualdade entre os estados (Gráfico 18). Contudo, na transição para e durante o ensino médio, a desigualdade nos estados do Nordeste cresce de forma mais acentuada, ainda que em ritmo semelhante entre os estados. 


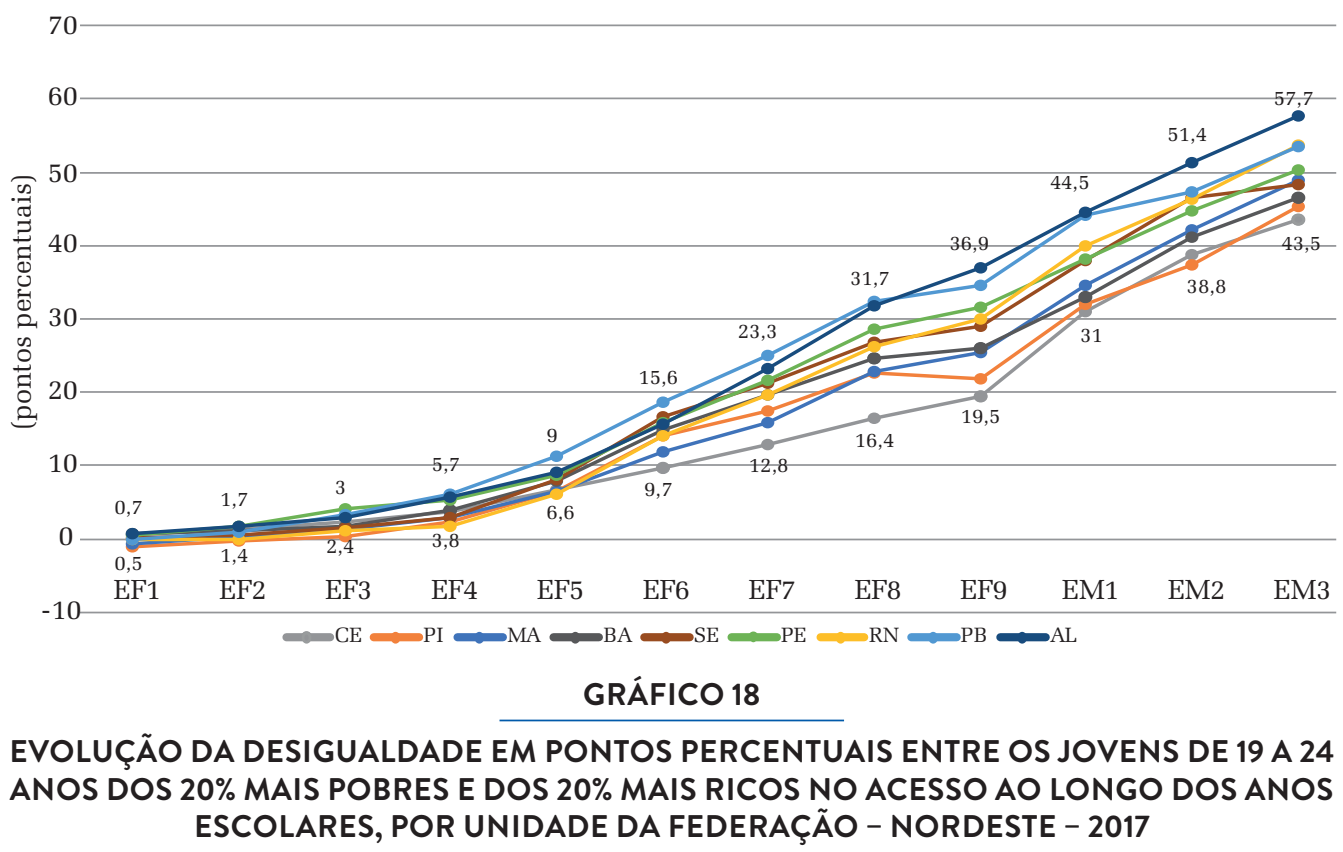

Fonte: Elaboração própria com base em dados de Pnad Contínua / IBGE (2017).

Na região Norte, a desagregação das curvas de acesso dos estados para os quintis superior e inferior da distribuição de renda domiciliar per capita apresenta perfil semelhante ao observado no Nordeste (Figura 5). A desigualdade de acesso começa a ser sentida já a partir do $6^{\circ}$ ano do ensino fundamental (com exceção do Pará e do Amazonas que já apresentam desigualdade a partir do $5^{\circ}$ ano). Rondônia aparece com a maior desigualdade de acesso devido à renda, com uma brecha de 48 p.p. no acesso ao $3^{\circ}$ ano do ensino médio entre o quinto e o primeiro quintis de renda. Este último quintil com apenas $42 \%$ de jovens de 19 a 24 anos alcançando o $3^{\circ}$ ano do ensino médio. Rondônia também se distancia dos demais estados da região por apresentar forte desigualdade de acesso também no $8^{\circ}$ e $9^{\circ}$ ano do ensino fundamental (Gráfico 19) entre os jovens pertencentes aos dois quintis analisados. Tocantins, que apresenta a melhor curva de acesso da região para os jovens de 19 anos (como visto no Gráfico 15), também apresenta a menor desigualdade ao longo dos anos escolares para o grupo de 19 a 24 anos, ainda que chegue ao $3^{\circ}$ ano do ensino médio com uma brecha de 37 p.p. Roraima apresenta uma curva de desigualdade entre os quintis analisados semelhante à de Tocantins, mas durante o ensino médio a desigualdade cresce fortemente colocando o estado no final do ensino médio com uma brecha de 45 p.p. no acesso, sendo o terceiro mais desigual no acesso da região, depois de Rondônia e Amapá. Os demais estados da região Norte apresentam uma evolução semelhante da brecha de acesso. 

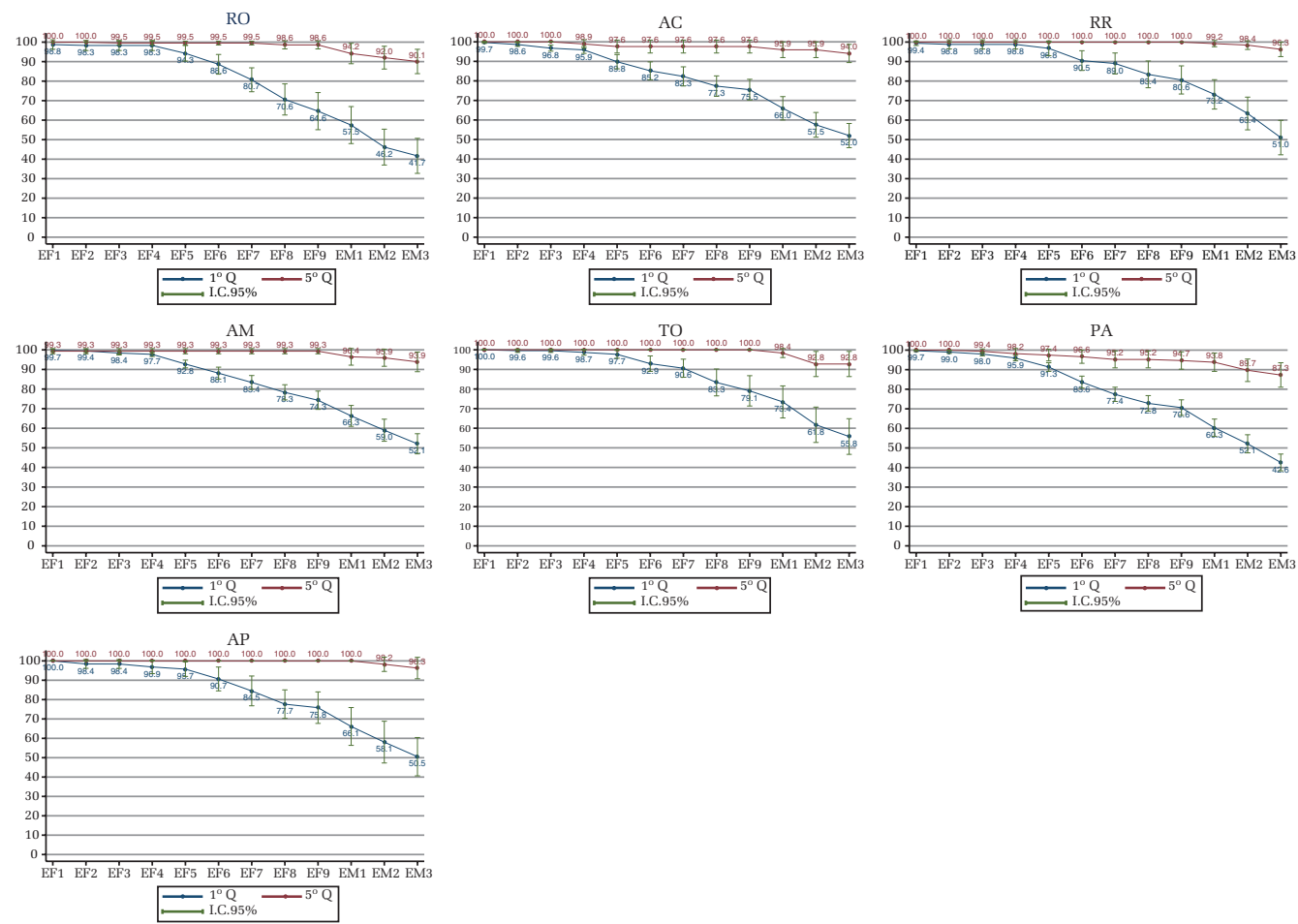

$\underbrace{10}_{1 . \mathrm{C} .95 \%}-5^{\circ} \mathrm{Q}$

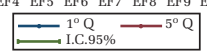

FIGURA 5

CURVAS DE ACESSO DA POPULAÇÃO DE 19 A 24 ANOS, SEGUNDO O QUINTIL DE RENDA DOMICILIAR PER CAPITA, POR UNIDADE DA FEDERAÇÃO - REGIÃO NORTE - 2017

Fonte: Elaboração própria com base em dados de Pnad Contínua / IBGE (2017).

$$
60
$$

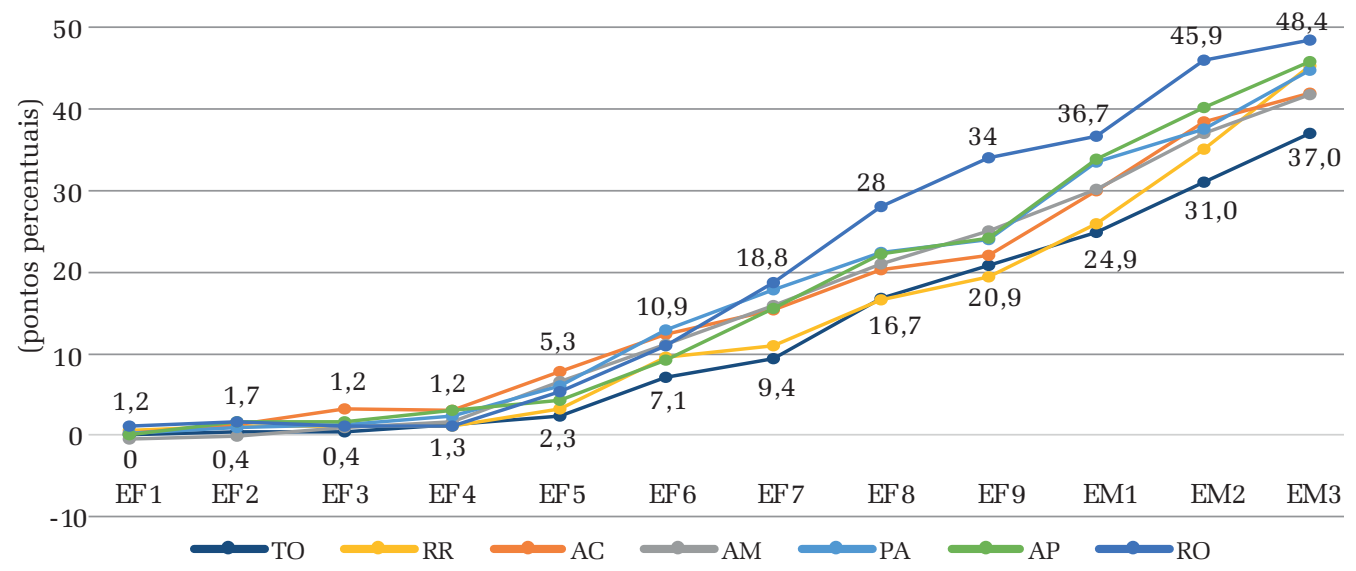

GRÁFICO 19

EVOLUÇÃO DA DESIGUALDADE EM PONTOS PERCENTUAIS ENTRE OS JOVENS DE 19 A 24 ANOS DOS 20\% MAIS POBRES E DOS 20\% MAIS RICOS NO ACESSO AO LONGO DOS ANOS ESCOLARES, POR UNIDADE DA FEDERAÇÃO - NORTE - 2017

Fonte: Elaboração própria com base em dados de Pnad Contínua / IBGE. 
Como visto anteriormente, a região Centro-Oeste apresenta a menor desigualdade de acesso entre os $20 \%$ mais pobres e os $20 \%$ mais ricos da população de 19 anos aos anos escolares do ensino fundamental (Gráfico 16). Contudo, no Mato Grosso e Mato Grosso do Sul, já se observam brechas de acesso expressivas entre o primeiro e o quinto quintis de renda da população de 19 a 24 anos a partir do $6^{\circ}$ ano do ensino fundamental (Figura 6). A maior brecha de acesso entre esses grupos ocorre no Mato Grosso do Sul, onde apenas 39\% dos jovens do quintil mais pobre chegou ao $3^{\circ}$ ano do ensino médio até $2017^{21}$. Ao final da educação básica, a desigualdade de acesso desse grupo de renda em relação aos $20 \%$ do topo da distribuição chega a 53 p.p. (Gráfico 20). O acesso dos mais pobres nesse estado é o mais baixo da região para todos os anos escolares a partir do $5^{\circ}$ ano do ensino fundamental, havendo grande "atrito" na passagem do $6^{\circ}$ para o $7^{0}$ ano, da ordem de 15 p.p., o maior do país ${ }^{22}$. Cabe ressaltar que tal "atrito" é inexistente em 12 dos 27 estados da Federação para o os jovens do quinto quintil de renda e, onde ele existe, não ultrapassa 2 p.p.

Até o ingresso no ensino médio, as brechas de acesso entre os $20 \%$ mais pobres e os $20 \%$ mais ricos, no Distrito Federal e em Goiás, são muito próximas, sendo as menores da região (Gráfico 20). Os mais pobres chegam ao $3^{\circ}$ ano do ensino médio em proporções equivalentes nesses dois estados (em torno de 55\%), e cerca de três quartos desses jovens ingressam no ensino médio (Figura 6).

${ }^{21}$ Mato Grosso do Sul tem melhor acesso para a população dos 20\% mais pobres apenas quando comparado ao Rio Grande do Sul (34,5\%) e ao Paraná (36,7\%).

${ }^{22}$ Depois de Mato Grosso do Sul, os estados que apresentam maior “atrito” do $6^{\circ}$ para o $7^{\circ}$ ano para os mais pobres são: Rondônia (7,9 p.p.), Alagoas (7,7 p.p.) e Rio Grande do Norte (7,6 p.p.). Nesses estados, o "atrito" é cerca de metade do encontrado em Mato Grosso do Sul. 
MS

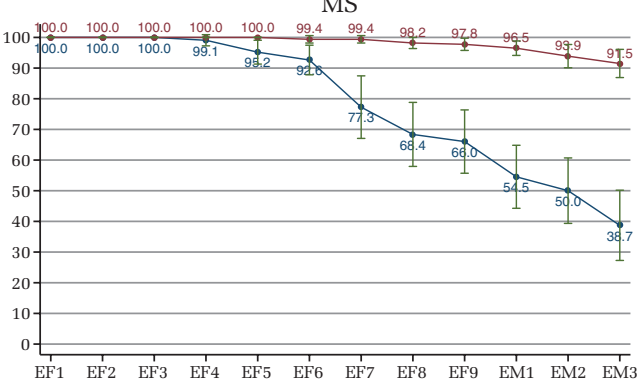

$\longrightarrow 1^{\circ} \mathrm{Q} \longrightarrow 5^{\circ} \mathrm{Q}$

GO

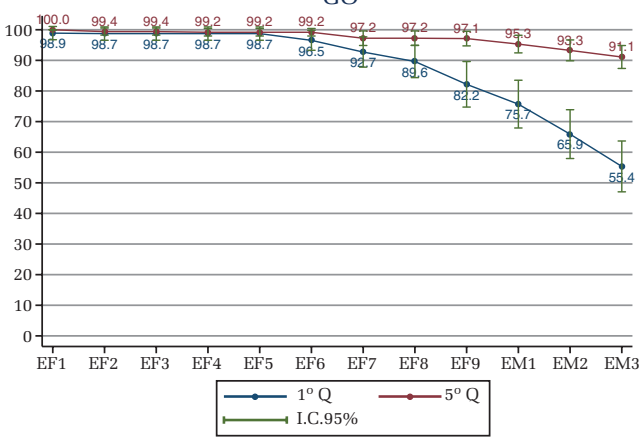

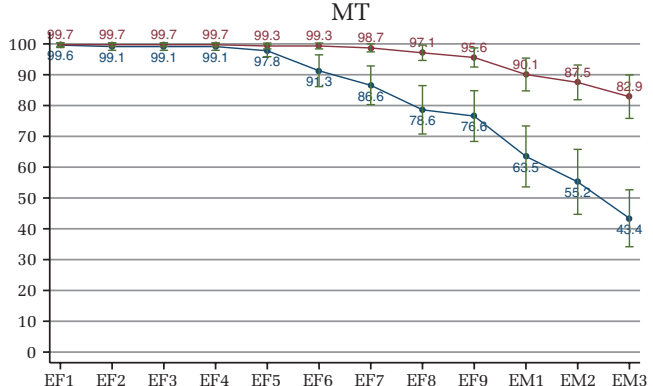

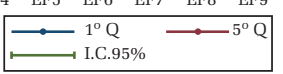

$\mathrm{DF}$

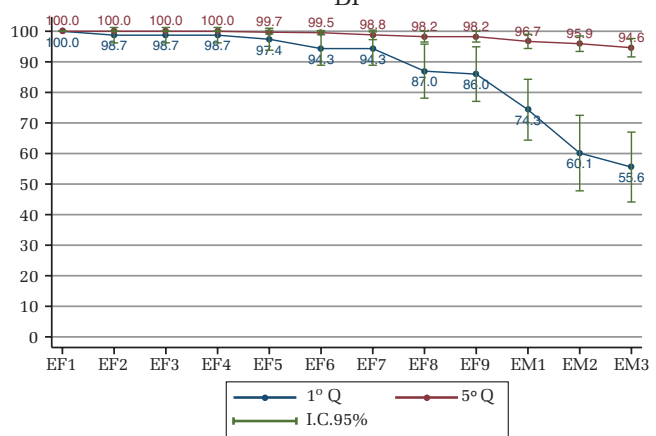

FIGURA 6

CURVAS DE ACESSO DA POPULAÇÃO DE 19 A 24 ANOS, SEGUNDO O QUINTIL DE RENDA DOMICILIAR PER CAPITA, POR UNIDADE DA FEDERAÇÃO - REGIÃO CENTRO-OESTE - 2017

Fonte: Elaboração própria com base em dados de Pnad Contínua / IBGE (2017).

60

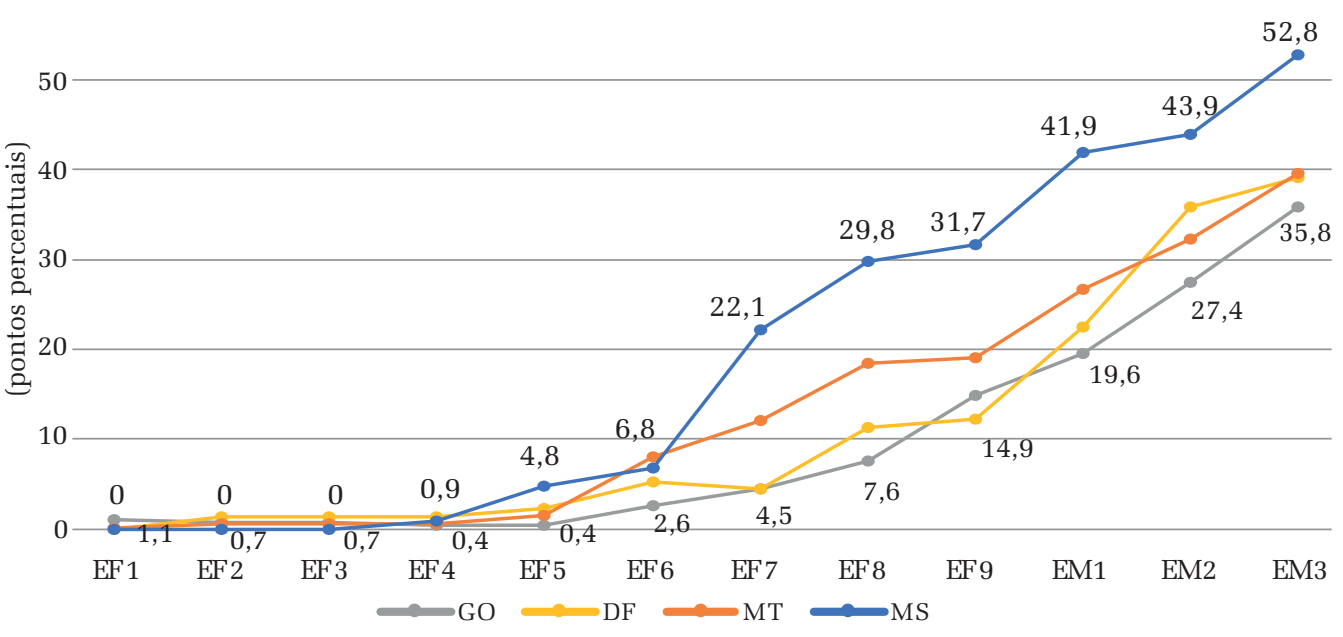

GRÁFICO 20

EVOLUÇÃO DA DESIGUALDADE EM PONTOS PERCENTUAIS ENTRE OS JOVENS DE 19 A 24 ANOS DOS 20\% MAIS POBRES E DOS 20\% MAIS RICOS NO ACESSO AO LONGO DOS ANOS ESCOLARES, POR UNIDADE DA FEDERAÇÃO - CENTRO-OESTE - 2017

Fonte: Elaboração própria com base em dados de Pnad Contínua / IBGE (2017) 
A região Sul foi destacada anteriormente como a região de maior desigualdade de acesso à educação básica no Brasil, considerando como parâmetro de análise a diferença no percentual dos jovens de 19 anos, por grupos de renda, que alcançam os anos escolares da educação básica (Figura 2). A Figura 7 abaixo mostra as curvas de acesso desagregadas para os quintis superior e inferior da renda domiciliar per capita dos jovens de 19 a 24 anos, evidenciando essa desigualdade nos estados. Temos, na região Sul, os dois estados brasileiros com o mais baixo acesso à educação básica de forma integral e universal, ou seja, o acesso de todos a todos os anos escolares desse nível de ensino. No Paraná (PR), apenas 37\% dos jovens pertencentes aos $20 \%$ mais pobres chegaram a alcançar o $3^{\circ}$ ano do ensino médio até 2017. No Rio Grande do Sul (RS), o percentual é ainda menor, chegando só a 35\%. Esse estado também mantém o mais baixo ingresso dos jovens do quintil inferior no ensino médio do país (52\%).

As curvas de acesso do PR e RS são muito semelhantes, sugerindo possíveis dificuldades comuns. Já Santa Catarina (SC) se destaca na região, apresentando a melhor curva de acesso e a menor desigualdade entre os jovens dos quintis superior e inferior em todos os anos escolares da educação básica. No segundo ciclo do ensino fundamental, SC apresenta uma das melhores condições de acesso aos mais pobres, dividindo com São Paulo, Goiás e o Distrito Federal essa condição. Contudo, na passagem para e durante o ensino médio, a desvantagem do quintil inferior de renda no acesso vai se acentuar, levando o estado a se posicionar no quartil inferior de desempenho quanto ao acesso dos mais pobres ao $3^{\circ}$ ano do ensino médio (43\%).

O Gráfico 21 mostra a desigualdade de acesso por ano escolar entre os $20 \%$ mais pobres e os $20 \%$ mais ricos nos três estados da região Sul. As desigualdades no PR e RS são muito semelhantes, chegando a dobrar entre o $9^{\circ}$ ano e o $3^{\circ}$ ano do ensino médio nesses dois estados. 

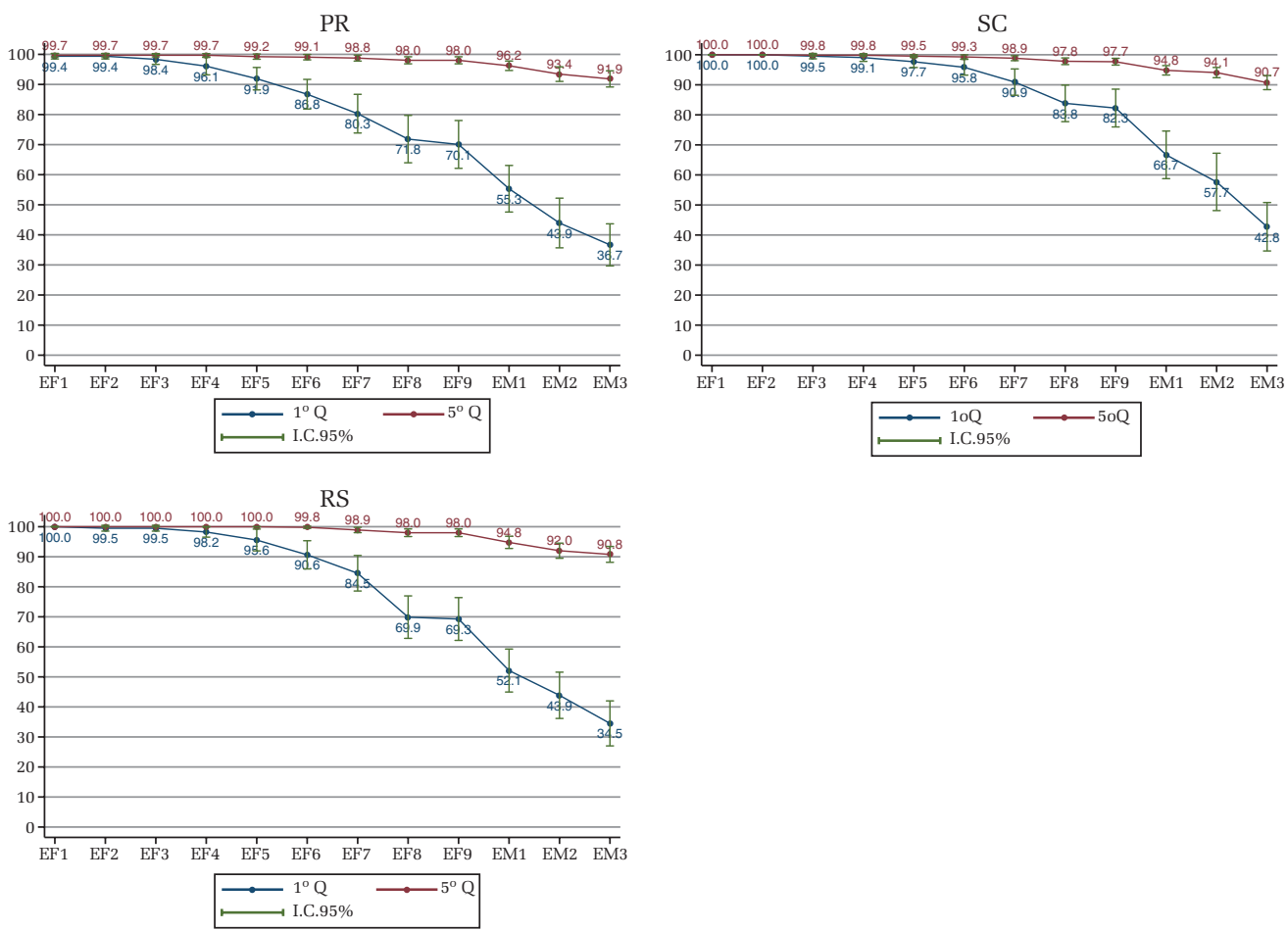

FIGURA 7

CURVAS DE ACESSO DA POPULAÇÃO DE 19 A 24 ANOS, SEGUNDO O QUINTIL DE RENDA DOMICILIAR PER CAPITA, POR UNIDADE DA FEDERAÇÃO - REGIÃO SUL - 2017

Fonte: Elaboração própria com base em dados de Pnad Contínua / IBGE (2017).

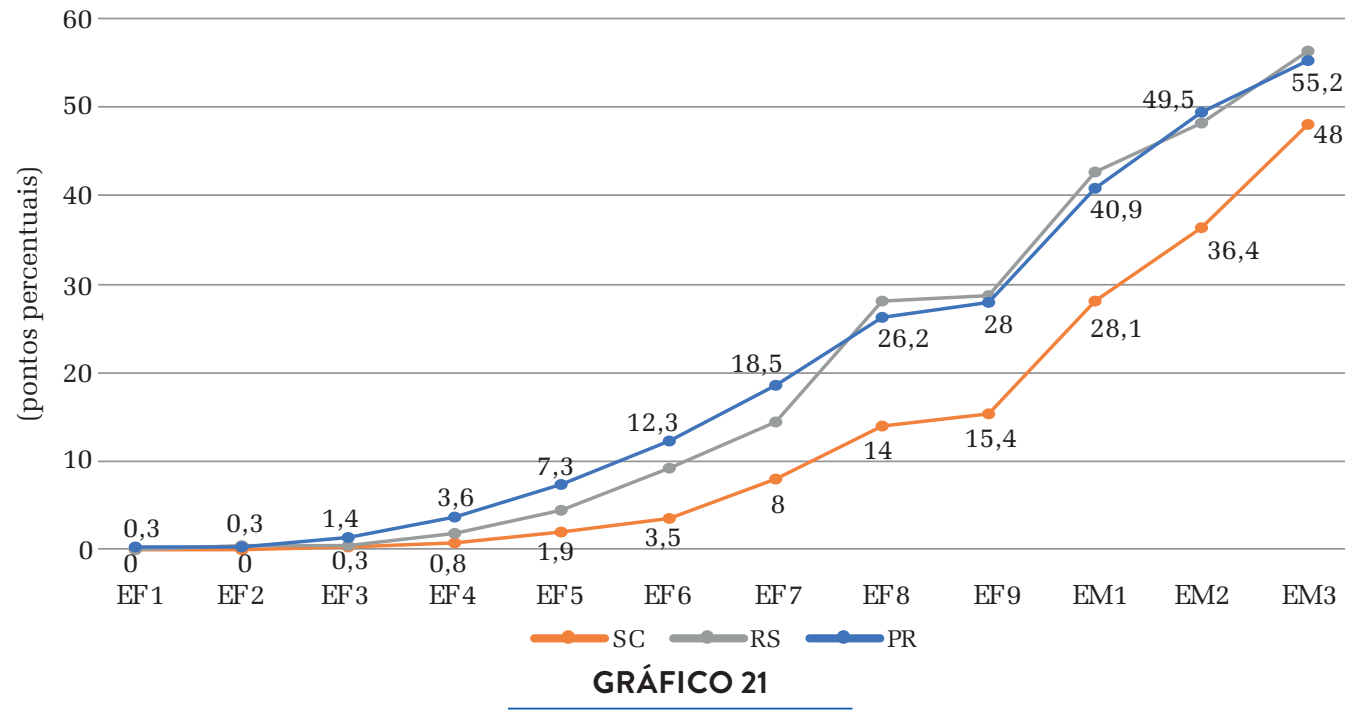

EVOLUÇÃO DA DESIGUALDADE EM PONTOS PERCENTUAIS ENTRE OS JOVENS DE 19 A 24 ANOS DOS 20\% MAIS POBRES E DOS 20\% MAIS RICOS NO ACESSO AO LONGO DOS ANOS ESCOLARES, POR UNIDADE DA FEDERAÇÃO - SUL - 2017

Fonte: Elaboração própria com base em dados de Pnad Contínua / IBGE (2017). 
Os Gráficos A-4, A-5 e A-6, no apêndice, mostram os estados em ordem de desigualdade de acesso entre os jovens de 19 a 24 anos dos quintis extremos da distribuição de renda por ano de transição entre etapas da educação básica. No $5^{\circ}$ ano do ensino fundamental, as menores desigualdades são vistas em Goiás (0,4 p.p.), São Paulo (0,9 p.p.) e Mato Grosso (1,6 p.p.); as maiores estão em Pernambuco (8,6 p.p.), Alagoas (9 p.p.) e Paraíba (11,3 p.p.). No $9^{\circ}$ ano do ensino fundamental, aparecem no topo do ranking de desigualdade de acesso os estados de Rondônia (34 p.p.), Paraíba (34,6 p.p.) e Alagoas (36,9 p.p.), enquanto entre os estados com menor desigualdade no $9^{\circ}$ ano devido à renda estão São Paulo (10,9 p.p.), Distrito Federal (12,3 p.p.) e Goiás (14,9 p.p.). Ao final da educação básica, a brecha de acesso alcançada no $3^{\circ}$ ano é maior no Paraná (55,2 p.p.), Rio Grande do Sul (56,3 p.p.) e Alagoas (57,7 p.p.). Já as menores desigualdades são vistas em São Paulo (34,6\%), Goiás (35,8\%) e Tocantins $(37,0 \%)$. Portanto, São Paulo e Goiás apresentam as menores desigualdades de acesso ao longo da educação básica.

A evolução da desigualdade de acesso dos jovens de 19 a 24 anos entre os $20 \%$ mais pobres e os $20 \%$ mais ricos ao longo dos anos escolares da educação básica para o conjunto dos estados brasileiros (Gráfico 22) mostra que, nos anos iniciais do ensino fundamental, a desigualdade dos grupos varia pouco entre os estados (pequeno desvio padrão ${ }^{23}$ ), embora aumente com o ano escolar até o $5^{\circ}$ ano em vários estados. Ainda, a expansão da desigualdade no acesso aos anos escolares dessa etapa segue um ritmo menos desigual entre os estados. Isso mostra que o Brasil alcançou uma igualdade maior entre os grupos de baixa e alta renda nos anos iniciais e que os estados se diferenciam pouco quanto ao acesso a essa etapa.

Já na segunda etapa do ensino fundamental, observa-se uma desigualdade maior no acesso entre os grupos de renda, e a expansão dessa desigualdade ao longo dos anos escolares segue ritmos muito distintos entre os estados. Isso coloca o segundo ciclo do ensino fundamental como foco na geração da desigualdade de acesso à educação básica no Brasil entre os estados. É necessário, portanto, que se investiguem as causas do aumento da desigualdade nessa etapa, bem como as políticas que estão a levar a uma maior dispersão da desigualdade de acesso devido à renda entre os estados. Fica evidente que alguns estados são mais efetivos do que outros em promover o direito de acesso à educação básica de forma universal e integral.

$\mathrm{Na}$ transição para e durante o ensino médio, a desigualdade de acesso entre os jovens do primeiro e quinto quintis de renda cresce, em média, a uma taxa mais elevada por ano escolar do que no ensino fundamental, mas o ritmo desse crescimento é menos desigual entre os estados, havendo redução da variação do desvio padrão da desigualdade entre os quintis de renda por ano escolar a partir do $1^{\circ}$ ano do ensino médio (Gráfico A-7). Há, portanto, no ensino médio, menor desigualdade entre os

${ }^{23}$ A média da desigualdade e o desvio padrão para o conjunto dos estados são apresentados no Gráfico A-7. 
estados no que tange à evolução da brecha de acesso entre os $20 \%$ mais pobres e os $20 \%$ mais ricos da população de 19 a 24 anos, embora seja nessa etapa que a desigualdade entre pobres e ricos mais cresça nos estados.

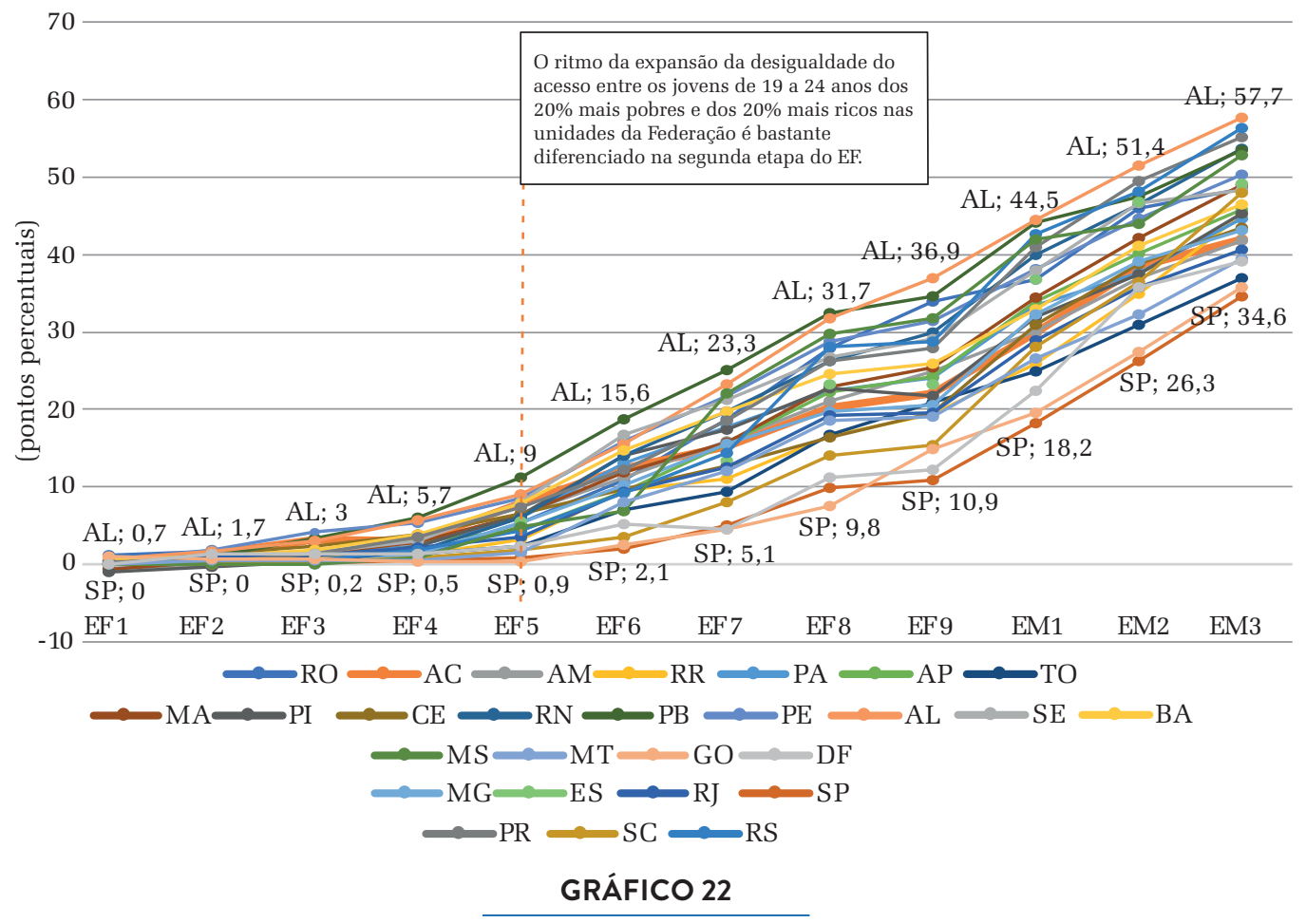

EVOLUÇ̃̃O DA DESIGUALDADE EM PONTOS PERCENTUAIS ENTRE OS JOVENS DE 19 A 24 ANOS DOS 20\% MAIS POBRES E DOS 20\% MAIS RICOS NO ACESSO AO LONGO DOS ANOS ESCOLARES, POR UNIDADE DA FEDERAÇÃO - TODOS OS ESTADOS - 2017

Fonte: Elaboração própria com base em dados de Pnad Contínua / IBGE (2017).

\section{UM OLHAR SOBRE A EVOLUÇÃO DO ACESSO À EDUCAÇÃO BÁSICA NO PERÍODO 2002-2017}

\subsection{BRASIL E GRANDES REGIÕES}

O acesso à educação básica, representado pela curva com o percentual dos jovens de 19 anos que alcançaram os diversos anos escolares até o ano de 2017, apresentada anteriormente no Gráfico 5, ainda que não satisfatório sob a perspectiva da universalidade e integralidade, resulta de um progresso ocorrido nos últimos 15 anos. O Gráfico 23 mostra essa evolução a partir do ano de 2002 em intervalos de cinco anos. Naquele ano, 
apenascerca de $70 \%$ dos jovens de 19 anoshaviaalcançadoofinaldoensinofundamental ${ }^{24}$ e 43\%, o $3^{\circ}$ ano do ensino médio. Em 2017, esses percentuais foram respectivamente 89\% (considerando já o $9^{\circ}$ ano como ano final do ensino fundamental) e $68 \%$. Houve, portanto, um progresso extraordinário no acesso escolar de 17 p.p. no ensino fundamental e de 24 p.p. no ensino médio entre 2002 e 2017.

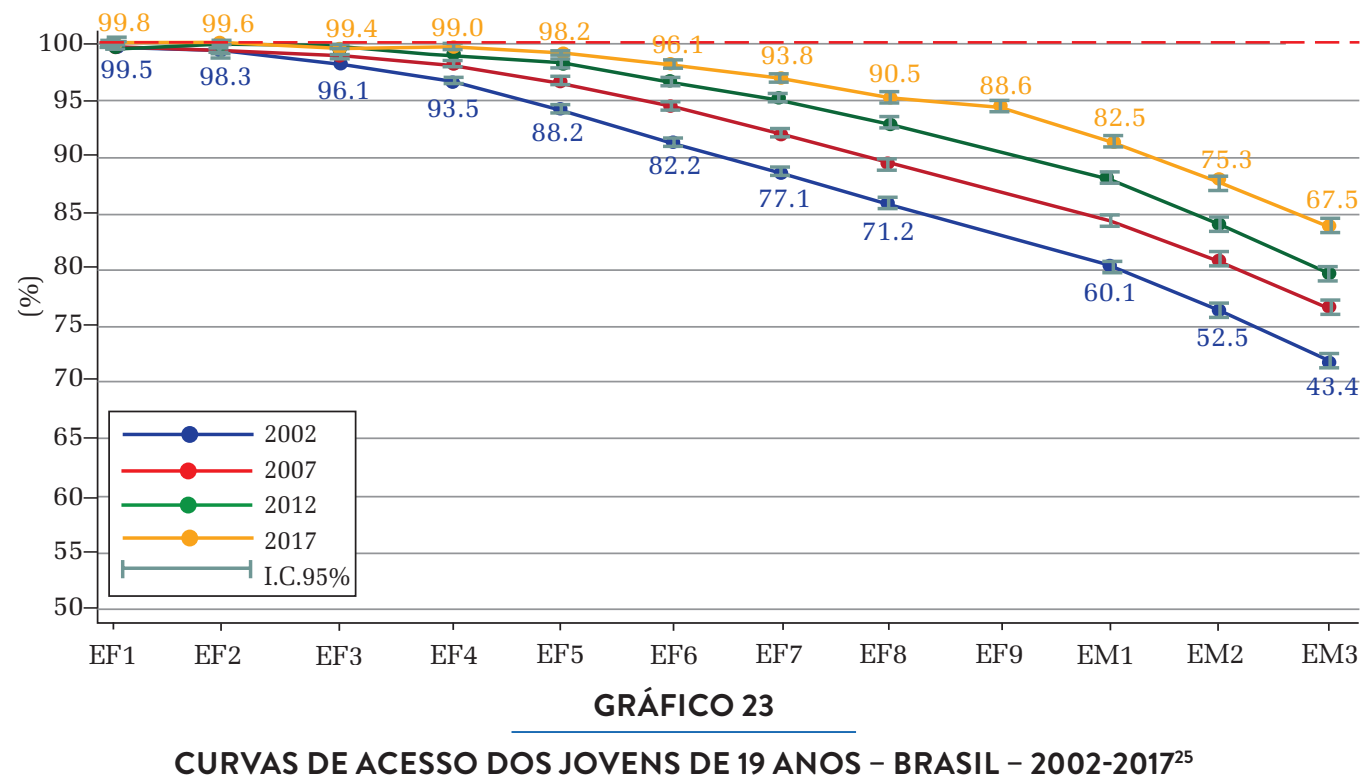

Fonte: Elaboração própria com base nos microdados de Pnad / IBGE (2002-2012) e Pnad Contínua (2017).

O progresso foi mais acentuado ainda se for considerado o grupo de renda que compreende os $20 \%$ mais pobres da população quando comparado aos $20 \%$ mais ricos, como mostram o Gráfico 24 e o Gráfico 25 a seguir. Para os $20 \%$ mais pobres, ocorreu avanço no acesso ao ano final do ensino fundamental de 38 p.p., bem como no acesso ao $3^{\circ}$ ano do ensino médio, entre os anos de 2002 e 2017, mostrando que houve uma evolução uniforme para os mais pobres quanto à terminalidade dessas duas etapas da educação básica. Já entre os 20\% mais ricos, houve avanço no acesso ao $3^{\circ}$ ano do ensino médio, que cresceu 12 p.p. no mesmo período. Já para o último ano do ensino fundamental, o acesso avançou menos ( 3 p.p.), visto que já era bastante alto para esse grupo no ano de 2002 (95\%).

${ }^{24} \mathrm{O}$ final do ensino fundamental era dado pela $8^{\mathrm{a}}$ série, pois o ensino fundamental de nove anos só foi implementado a partir de 2006, com a Lei $\mathrm{n}^{0} 11.274$.

${ }^{25}$ Para os anos 2002, 2007 e 2012, é utilizada a Pnad anual; para 2017, é utilizada a Pnad Contínua. Devido à coexistência de regime de oito e nove anos no ensino fundamental, os dois anos de terminalidade dessa etapa foram agregados na variável EF8 até 2012, sendo estimado o percentual de acesso ao $9^{\circ}$ ano de forma separada apenas para o ano de 2017. Por essa razão, não são apresentados os pontos das estimativas para a variável EF9 nos anos de 2002 a 2012. 


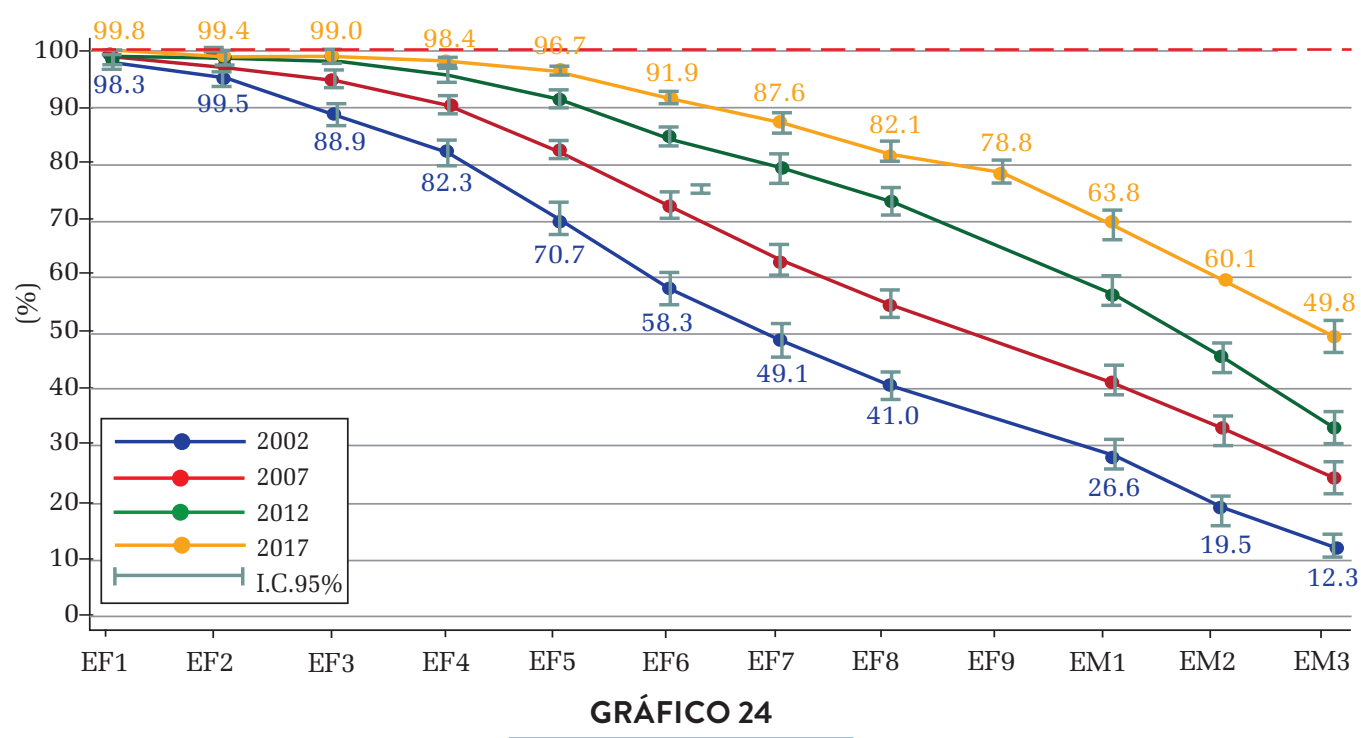

CURVAS DE ACESSO PARA OS JOVENS DE 19 ANOS DO $1^{\circ}$ QUINTIL DE RENDA DOMICILIAR PER CAPITA - BRASIL - 2002-2017

Fonte: Elaboração própria com base nos microdados de Pnad / IBGE (2002-2012) e Pnad Contínua (2017).

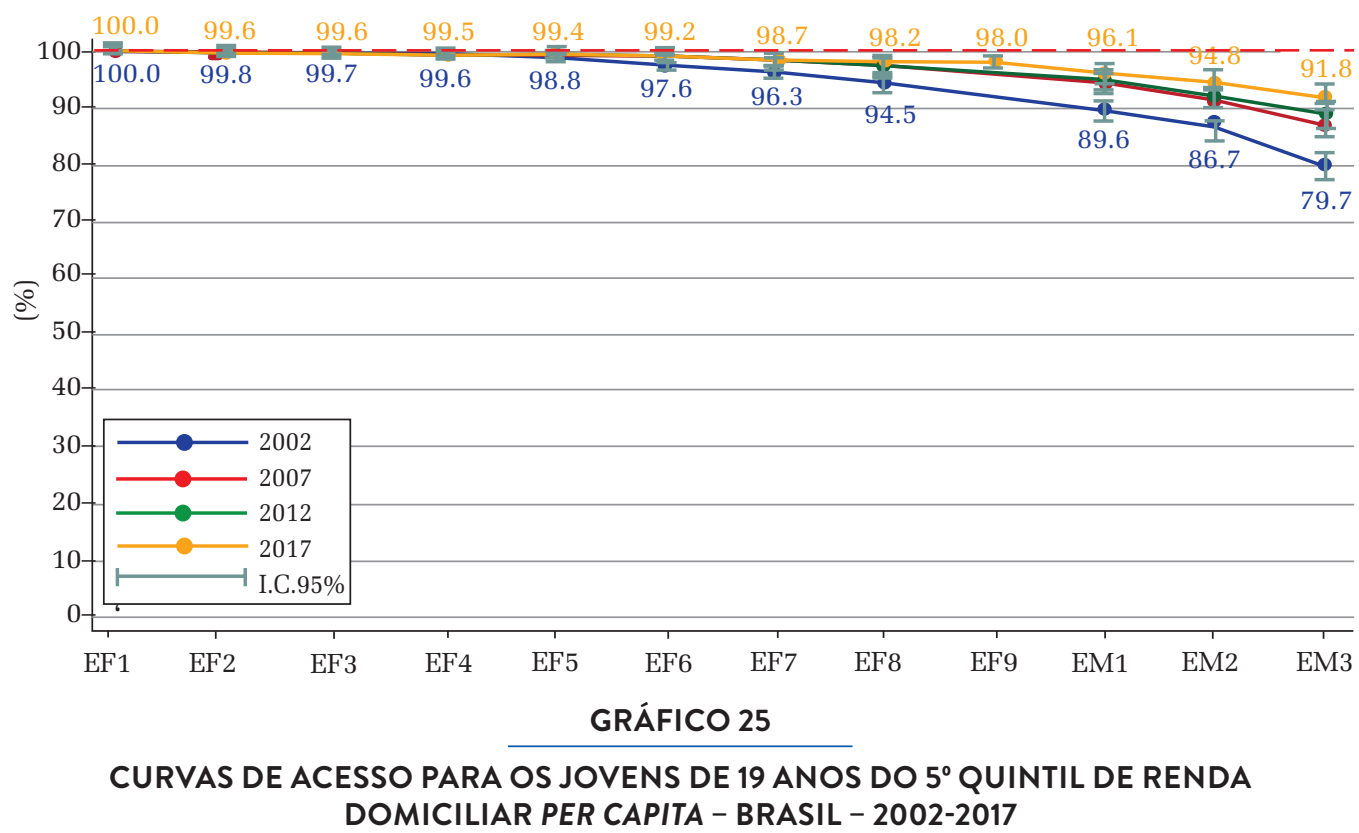

Fonte: Elaboração própria com base nos microdados de Pnad / IBGE (2002-2012) e Pnad Contínua (2017).

O caminho da universalização do acesso à educação básica passa fortemente pelo acesso dos grupos de renda mais baixa, o que significa enfrentar as desigualdades de acesso provocadas pela exclusão e pelo atraso escolar desses grupos ao longo de sua trajetória escolar. 
A evolução do acesso dos jovens de 19 anos pertencentes aos 20\% mais pobres da população por região geográfica pode ser visto na Figura 8. De modo geral, em todas as regiões se observa o aumento do acesso aos anos escolares desse grupo ao longo do período 2002-2017. No Norte, o maior avanço ocorreu entre 2012 e 2017, não havendo grande avanço antes desse período, salvo no acesso ao ensino médio entre 2002 e 2007, quando mais que dobra o percentual dos que alcançam o $3^{\circ}$ ano do ensino médio.

O Nordeste apresenta uma evolução consistente do acesso dos mais pobres a todas as etapas da educação básica ao longo do período analisado. O ganho de acesso ao ano final do ensino fundamental é bastante significativo, saindo de 35\% em 2002 para 77\% em 2017. Também o acesso ao $3^{\circ}$ ano do ensino médio no Nordeste observou um avanço extraordinário no período, saindo de 8\% em 2002 para 49\% em 2017.

O Centro-Oeste avançou muito no acesso dos mais pobres ao ensino fundamental e médio entre 2002 e 2007 e de novo entre 2007 e 2012, mas praticamente não se vê avanço entre 2012 e 2017 na região para esse grupo. Já no Sudeste, a melhoria do acesso dos mais pobres se distingue melhor após 2007, não tendo avançado muito no quinquênio anterior.

Finalmente, a região Sul, que melhorou bastante o acesso dos mais pobres entre 2002 e 2012, pouco avançou no último quinquênio, comportamento semelhante ao observado no Centro-Oeste.
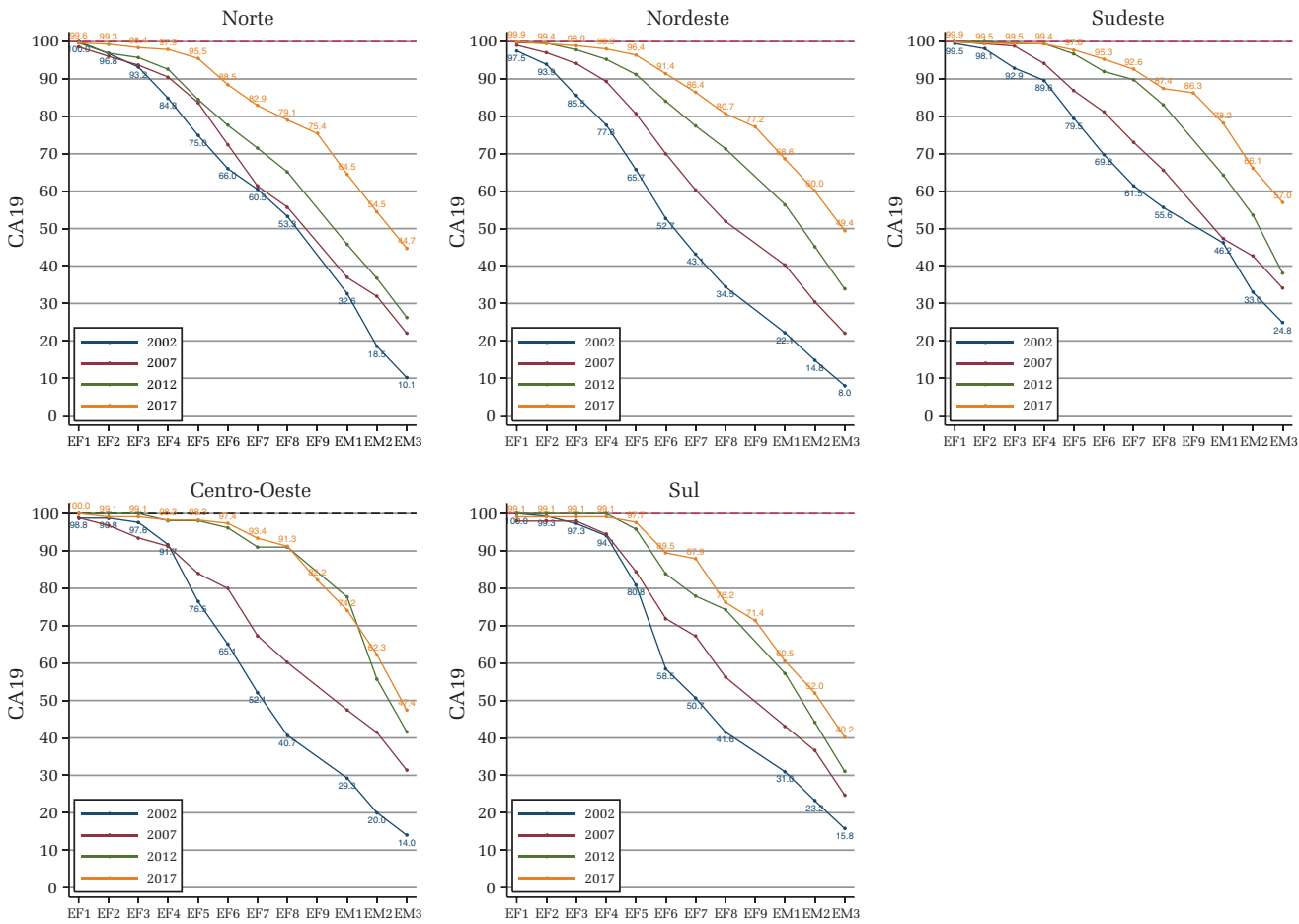

FIGURA 8 


\subsection{UNIDADES DA FEDERAÇÃO}

Na seção sobre a brecha de acesso nas unidades da Federação, foi mostrado que os estados com o melhor acesso à educação básica pra os jovens pertencentes aos $20 \%$ mais pobres, avaliados segundo o percentual daqueles entre 19 a 24 anos que conseguiram alcançar o $3^{\circ}$ ano do ensino médio até o ano de 2017 , são também os estados onde existe a menor brecha de acesso entre os quintis superior e inferior de renda. Os estados com melhor acesso dos mais pobres ao $3^{\circ}$ ano do ensino médio e a menor brecha entre estes e os $20 \%$ do topo da renda são: São Paulo, Tocantins, Distrito Federal e Goiás.

Já os estados com o pior acesso dos $20 \%$ mais pobres ao $3^{\circ}$ ano do ensino médio são também os que apresentam as maiores desigualdades de acesso a esse ano escolar comparado aos 20\% mais ricos. São eles: Rio Grande do Sul, Paraná, Mato Grosso do Sul e Alagoas ${ }^{26}$.

Entre os estados com o pior acesso dos mais pobres e a maior desigualdade entre estes e os $20 \%$ mais ricos, também estão três dos quatro estados com o menor avanço no acesso ao $3^{\circ}$ ano para a população de jovens do primeiro quintil de renda entre 2002 e 2017, sendo eles, na ordem: Paraná, Mato Grosso do Sul e Rio Grande do Sul (Figura 9). Já entre os estados com melhor acesso dos mais pobres ao $3^{\circ}$ ano do ensino médio e a menor brecha entre os quintis de renda, também se encontram dois dos quatro com os maiores avanços de acesso dos mais pobres: Tocantins e Goiás, seguidos de Piauí e Acre, este último tendo avançado 47 p.p. no acesso ao $3^{\circ}$ ano para os mais pobres, o maior do Brasil (Figura 9).

\footnotetext{
${ }^{26}$ Mato Grosso do Sul, no entanto, apresenta menor brecha (52,8 p.p.) entre os quintis de renda se comparado à Paraíba e ao Rio Grande do Norte, ambos com 53,6 p.p. em 2017.
} 


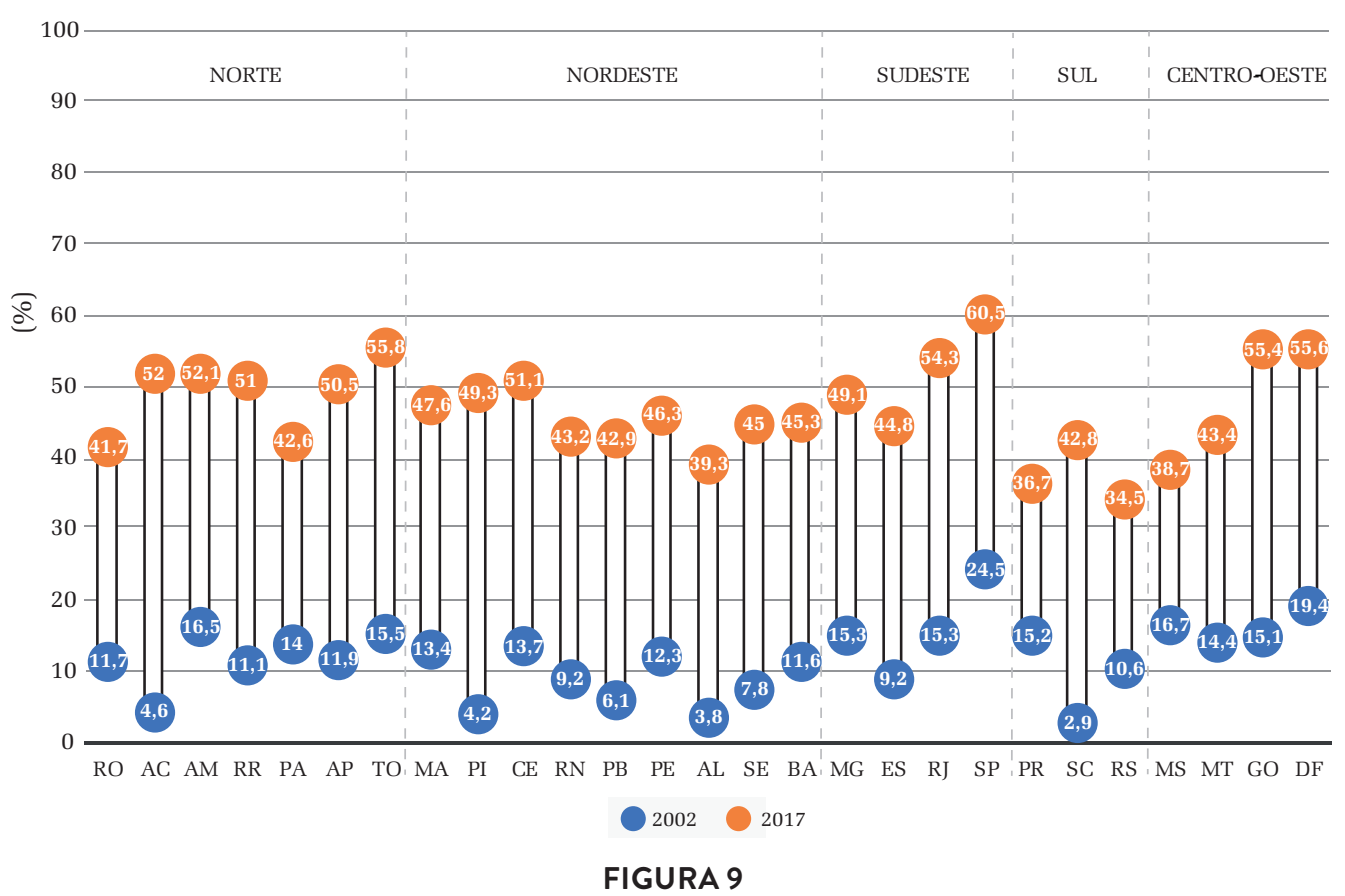

\section{PERCENTUAL DE JOVENS DE 19 A 24 ANOS DOS 20\% MAIS POBRES QUE CHEGARAM AO $3^{\circ}$ ANO DO ENSINO MÉDIO, POR UNIDADE DA FEDERAÇÃO - BRASIL - 2002/2017}

Fonte: Elaboração própria com base nos microdados de Pnad / IBGE (2002) e Pnad Contínua (2017).

Em síntese, temos a seguinte situação quanto ao acesso dos jovens de 19 a 24 anos pertencentes aos 20\% mais pobres em 2017, a desigualdade de acesso desse grupo devido à renda em relação aos 20\% mais ricos e o avanço dos $20 \%$ mais pobres entre 2002 e 2017 por ano escolar (Tabela 2):

TABELA 2

\section{ACESSO DOS 20\% MAIS POBRES (2017), BRECHA DE ACESSO COM OS 20\% MAIS RICOS (2017) E AVANÇO DOS 20\% MAIS POBRES ENTRE 2002 E 2017, POR ANO ESCOLAR DA EDUCAÇÃO BÁSICA - BRASIL}

\begin{tabular}{|c|c|c|c|c|}
\hline & $5^{0}$ ano & $9^{0}$ ano & $1^{0}$ médio & $3^{0}$ médio \\
\hline $\begin{array}{l}\text { Estados com o maior acesso } \\
\text { dos } 20 \% \text { mais pobres em } \\
2017\end{array}$ & $\begin{array}{l}\text { SP }(98,7) \\
\text { GO }(98,7) \\
\text { MT }(97,8 \%) \\
\text { TO }(97,7 \%) \\
\text { SC }(97,7 \%)\end{array}$ & $\begin{array}{l}\text { SP }(88,0 \%) \\
\text { DF }(86,0 \%) \\
\text { SC }(82,3 \%) \\
\text { GO }(82,2 \%)\end{array}$ & $\begin{array}{l}\text { SP }(79,3 \%) \\
\text { GO }(75,7 \%) \\
\text { DF }(74,3 \%) \\
\text { TO }(73,4 \%) \\
\text { RR }(73,2 \%)\end{array}$ & $\begin{array}{l}\text { SP }(60,5 \%) \\
\text { TO }(55,8 \%) \\
\text { DF }(55,6 \%) \\
\text { GO }(55,4 \%)\end{array}$ \\
\hline $\begin{array}{l}\text { Estados com o menor acesso } \\
\text { dos } 20 \% \text { mais pobres em } \\
2017\end{array}$ & $\begin{array}{l}\text { PE }(91,4 \%) \\
\text { PA }(91,3 \%) \\
\text { AL }(91,0 \%) \\
\text { AC }(89,8 \%) \\
\text { PB (88,7\%) }\end{array}$ & $\begin{array}{l}\text { MS }(66,0 \%) \\
\text { RO }(64,6 \%) \\
\text { PB }(63,2 \%) \\
\text { AL }(62,6 \%)\end{array}$ & $\begin{array}{l}\text { PR (55,3\%) } \\
\text { MS (54,5\%) } \\
\text { PB (53,6\%) } \\
\text { AL (53,6\%) } \\
\text { RS (52,1\%) }\end{array}$ & $\begin{array}{l}\text { AL (39,3\%) } \\
\text { MS (38,7\%) } \\
\text { PR (36,7\%) } \\
\text { RS (34,5\%) }\end{array}$ \\
\hline
\end{tabular}


TABELA 2

\section{ACESSO DOS 20\% MAIS POBRES (2017), BRECHA DE ACESSO COM OS 20\% MAIS RICOS (2017) E AVANÇO DOS 20\% MAIS POBRES ENTRE 2002 E 2017, POR ANO ESCOLAR DA EDUCAÇÃO BÁSICA - BRASIL}

\begin{tabular}{|c|c|c|c|c|}
\hline & & & & (cono \\
\hline & $5^{0}$ ano & $9^{0}$ ano & $1^{0}$ médio & $3^{0}$ médio \\
\hline $\begin{array}{l}\text { Estados com a maior brecha } \\
\text { de acesso entre os } 20 \% \text { mais } \\
\text { pobres e os } 20 \% \text { mais ricos } \\
\text { em } 2017\end{array}$ & $\begin{array}{l}\text { PB (11.3p.p.) } \\
\text { AL (9p.p.) } \\
\text { PE (8.6p.p.) }\end{array}$ & $\begin{array}{l}\text { AL (36,9p.p.) } \\
\text { PB (34,5p.p.) } \\
\text { RO (34,0p.p.) }\end{array}$ & $\begin{array}{l}\text { AL (44,5p.p.) } \\
\text { PB (44,1p.p.) } \\
\text { RS (42,7p.p.) } \\
\text { MS (42,0p.p.) }\end{array}$ & $\begin{array}{l}\text { AL (57,7p.p.) } \\
\text { RS (56,3p.p.) } \\
\text { PR (55,2p.p.) } \\
\text { PB e RN } \\
\text { (53,6p.p.) }\end{array}$ \\
\hline $\begin{array}{l}\text { Estados com a menor } \\
\text { brecha de acesso entre os } \\
20 \% \text { mais pobres e os } 20 \% \\
\text { mais ricos em } 2017\end{array}$ & $\begin{array}{l}\text { SC (1,8p.p.) } \\
\text { MT (1,5p.p.) } \\
\text { SP (0,8p.p.) } \\
\text { GO (0,5p.p.) }\end{array}$ & $\begin{array}{l}\text { SC (15,4p.p.) } \\
\text { GO (14,9p.p.) } \\
\text { DF (12,2p.p.) } \\
\text { SP (10,9p.p.) }\end{array}$ & $\begin{array}{l}\text { TO (25,0p.p.) } \\
\text { DF (22,4p.p.) } \\
\text { GO (19,6p.p.) } \\
\text { SP (18,2p.p.) }\end{array}$ & $\begin{array}{l}\text { DF (39,9P.P.) } \\
\text { TO (37,0p.p.) } \\
\text { GO (35,7p.p.) } \\
\text { SP (34,6p.p.) }\end{array}$ \\
\hline $\begin{array}{l}\text { Estados com o maior avanço } \\
\text { no acesso dos } 20 \% \text { mais } \\
\text { pobres entre } 2002 \text { e } 2017\end{array}$ & $\begin{array}{l}\text { AL (45,9p.p.) } \\
\text { PI (41,3p.p.) } \\
\text { PB (39,5p.p.) }\end{array}$ & $\begin{array}{l}\text { GO (52,2p.p.) } \\
\text { AC (51,7p.p.) } \\
\text { PI (50,1p.p.) }\end{array}$ & $\begin{array}{l}\text { SC (52,4p.p.) } \\
\text { GO (51,0p.p.) } \\
\text { PI (49,6p.p.) }\end{array}$ & $\begin{array}{l}\text { AC (47,4p.p.) } \\
\text { PI (45,1p.p.) } \\
\text { GO (40,3p.p.) } \\
\text { TO (40,3p.p.) }\end{array}$ \\
\hline $\begin{array}{l}\text { Estados com o menor } \\
\text { avanço no acesso dos } 20 \% \\
\text { mais pobres entre } 2002 \text { e } \\
2017\end{array}$ & $\begin{array}{l}\text { AP (14,3p.p.) } \\
\text { DF (13,9p.p.) } \\
\text { RR (4,2p.p.) }\end{array}$ & $\begin{array}{l}\text { MS (27,9p.p.) } \\
\text { RR (21,3p.p.) } \\
\text { AP (15,3p.p.) }\end{array}$ & $\begin{array}{l}\text { PA (31,1p.p.) } \\
\text { MS (25,9p.p.) } \\
\text { AP (23,2p.p.) }\end{array}$ & $\begin{array}{l}\text { RS (23,9p.p.) } \\
\text { MS (22,0p.p.) } \\
\text { PR (21,5p.p.) }\end{array}$ \\
\hline
\end{tabular}

Fonte: Elaboração própria com base nos microdados de Pnad / IBGE (2002) e Pnad Contínua (2017).

Os estados brasileiros têm apresentado avanços quanto ao acesso dos mais pobres à educação básica em todas as suas etapas. Estados com maior acesso dos $20 \%$ mais pobres aos anos de transição de etapa escolar da educação básica também apresentam as menores brechas de acesso entre esse grupo e os $20 \%$ mais ricos. Por outro lado, estados com menor progresso no acesso dos mais pobres entre 2002 e 2017 apresentam menor acesso desses aos anos finais do ensino fundamental e ao ensino médio e maior desigualdade de acesso em relação aos $20 \%$ mais ricos.

\section{CONSIDERAÇÕES FINAIS}

O discurso difundido a partir de meados dos anos 80 sobre a universalização do acesso à escolaridade obrigatória não se sustentava à época, como mostrou Ferraro em suas análises, e não se sustenta ainda hoje. Ainda que se use o indicador da taxa de frequência escolar como critério de aferição do acesso e sua universalização em idade obrigatória, temos que 1,5 milhão de crianças e jovens de 4 a 17 anos (3\% do total) estavam fora da escola em 2017, tendo, 57\% deles, idade entre 15 e 17 anos. Nessa faixa etária, assim como nas demais ( 4 a 5 e 6 a 14), os $40 \%$ mais pobres compreendem mais de dois terços dos excluídos. Existe, portanto, forte desvantagem associada à 
renda no acesso à educação básica, mesmo quando se utiliza o critério da frequência escolar em idade obrigatória.

A análise das curvas de acesso e suas desagregações para grupos sociais, regiões e estados permite avaliar melhor a situação do acesso à educação básica no Brasil. Ao evidenciar as desigualdades e as grandes lacunas ainda existentes no acesso escolar, este trabalho mostra que a perspectiva teórica da igualdade-desigualdade, sugerida por Ferraro (2018) para diagnosticar o alcance da universalização do acesso à educação básica, pode ser instrumentalizada com o uso das curvas de acesso. Essa abordagem é relevante no caso do Brasil, dados os abismos que separam determinados grupos sociais e regiões do País na realização do direito subjetivo à educação obrigatória.

Ao se analisar o acesso escolar a partir dos atributos da integralidade e da universalidade por meio das curvas de acesso, fica evidente que cerca de um em cada três jovens de 19 anos ou estão defasados, portanto em risco de exclusão, ou já deixaram a escola antes de concluir a educação básica. A renda domiciliar per capita responde pela maior desigualdade observada no acesso aos anos escolares dos jovens de 19 anos, surgindo na transição para a segunda etapa do ensino fundamental e se acentuando durante todo o percurso até o $3^{\circ}$ ano do ensino médio. Ainda, se observam diferenças expressivas entre homens e mulheres, negros e brancos e moradores de áreas urbanas e rurais. Os homens negros do quintil mais baixo de renda são os mais afetados pela exclusão do acesso à educação básica, inclusive nos anos iniciais do ensino fundamental, com cerca de $10 \%$ dos jovens de 19 a 24 anos desse grupo sequer alcançando o $5^{\circ}$ ano. Portanto, o sistema educacional brasileiro apresenta uma ineficiência seletiva caracterizada pelo viés racial e de renda na formação de grupos em condições de atraso ou exclusão escolar.

O processo de exclusão da escola daqueles que um dia a frequentaram pôde ser mais bem descrito por meio da análise da curva de acesso dos $20 \%$ mais pobres entre os jovens de 19 anos evadidos do sistema de ensino. Grande parte da evasão desses jovens e do crescimento da desigualdade em relação aos $20 \%$ mais ricos ocorre a partir da transição e durante a segunda etapa do ensino fundamental. Entre os mais pobres que já haviam deixado a escola aos 19 anos, apenas metade conseguiu concluir o ensino médio, e um em cada quatro sequer concluiu o ensino fundamental. Para os jovens pobres e negros que já não estudam, o acesso foi ainda mais limitado, visto que um em cada três não conseguiu concluir o ensino fundamental e menos de $40 \%$ concluiu o ensino médio.

As desigualdades de acesso também são expressivas entre diferentes regiões e estados. Em geral, observa-se o mesmo padrão: crescimento da desigualdade durante a segunda etapa do ensino fundamental e maior "atrito" à medida que se avança de uma etapa a outra da educação básica, ou seja, uma maior proporção de crianças e jovens que são excluídos ou se atrasam no percurso da trajetória escolar à medida que se avança nos anos escolares. 
A região Sudeste é a que oferece o melhor acesso em média, e também para os 20\% mais pobres, ao conjunto da educação básica, apresentando a menor desigualdade de acesso devido à renda entre as regiões. É no Sudeste também onde há o menor crescimento da desigualdade durante o ensino fundamental, embora apresente o maior crescimento da desigualdade entre ricos e pobres a partir da transição e durante o ensino médio. São Paulo é o estado que garante o maior acesso, inclusive para os 20\% mais pobres, e apresenta a menor desigualdade entre pobres e ricos no Brasil. Lá, sessenta por cento (60\%) dos jovens de 19 a 24 anos dos $20 \%$ mais pobres chegaram ao $3^{\circ}$ ano do ensino fundamental até 2017. Ainda assim, um em cada cinco jovens de 19 anos ou estava em atraso escolar em 2017 ou já havia evadido do sistema de ensino.

A região Sul, por outro lado, é a que apresenta a maior desigualdade de acesso entre pobres e ricos e as maiores brechas de acesso a partir do $8^{\circ}$ ano entre esses dois grupos para todos os anos escolares. Nesta região, encontram-se os dois estados com o pior desempenho no acesso para os mais pobres (Rio Grande do Sul e Paraná).

O Ceará apresenta a melhor curva de acesso para os jovens de 19 anos do Nordeste e também para os $20 \%$ mais pobres de 19 a 24 anos, apresentando a menor desigualdade devido à renda do Nordeste. Por outro lado, Alagoas apresenta o maior acesso do País para os 20\% mais ricos, enquanto Rio Grande do Sul apresenta o menor acesso para os $20 \%$ mais pobres, seguido do Paraná, Mato Grosso do Sul e Alagoas. Esses são estados que também apresentam as maiores desigualdades de acesso entre pobres e ricos em todo o Brasil. Os estados com o melhor acesso para os mais pobres - São Paulo, Goiás, Distrito Federal e Tocantins - também apresentam as menores brechas de acesso entre pobres e ricos.

As curvas de acesso dos estados, em geral, sugerem uma clara barreira de acesso entre o ensino fundamental e o médio, e exigem mais investigação sobre a natureza de tal barreira. Esta pode ter origem no padrão de oferta ou no comportamento da demanda. De todo modo, a desigualdade de acesso entre os $20 \%$ mais pobres e os $20 \%$ mais ricos tende a crescer mais na transição para o ensino médio e durante esta etapa.

A análise das curvas de acesso dos estados mostra que a desigualdade entre pobres e ricos cresce de forma muito desigual ao longo dos anos escolares. Durante os anos iniciais do ensino fundamental, a desigualdade entre pobres e ricos da faixa de 19 a 24 anos cresce pouco e também varia pouco entre os estados. Desse modo, pode-se dizer que o Brasil alcançou uma igualdade maior entre os grupos de alta e baixa renda nos anos iniciais e que os estados se diferenciam pouco em relação a essa etapa. Na segunda etapa do ensino fundamental, a desigualdade é maior entre pobres e ricos e a sua expansão segue ritmos muito diferentes entre os estados. Fica claro, portanto, que alguns estados são mais efetivos na promoção do direito ao acesso ao ensino fundamental de forma integral e universal. Por outro lado, a desigualdade cresce em ritmo mais acentuado a partir do ensino médio, mas com menor diferença no ritmo do crescimento entre os estados. 
Apesar dos desafios ainda presentes para que se alcance a universalização da educação básica, o Brasil apresentou um progresso extraordinário no acesso escolar entre 2002 e 2017. Houve, neste período, avanço de 17 p.p. no acesso ao $9^{\circ}$ ano do ensino fundamental e de 24 p.p. no acesso ao $3^{\circ}$ ano do ensino médio para os jovens de 19 anos. Para os 20\% mais pobres, o progresso foi ainda maior, de 38 p.p. no acesso ao $9^{\circ}$ ano do ensino fundamental e ao $3^{\circ}$ ano do ensino médio. $\mathrm{O}$ avanço dos mais pobres no Nordeste foi extraordinário entre 2002 e 2017, 42 p.p. no $9^{\circ}$ ano e 41 p.p. no $3^{\circ}$ ano.

O caminho da universalização do acesso à educação básica, tal como foi conceituado neste trabalho, passa fundamentalmente pela promoção do acesso integral aos anos escolares dos grupos de baixa renda. Enfrentar as causas da desigualdade de acesso, em particular da exclusão escolar dos mais pobres ao longo de sua trajetória, é condição necessária para que se avance nas metas de universalização definidas no Plano Nacional de Educação.

\section{REFERÊNCIAS}

BRASIL. Constituição (1988). Constituição da República Federativa do Brasil. Brasília, 1988.

BRASIL. Constituição (1988). Emenda Constitucional no 59, de 11 de novembro de 2009. Acrescenta $\S 3^{\circ}$ ao art. 76 do Ato das Disposições Constitucionais Transitórias para reduzir, anualmente, a partir do exercício de 2009, o percentual da Desvinculação das Receitas da União incidente sobre os recursos destinados à manutenção e desenvolvimento do ensino de que trata o art. 212 da Constituição Federal, dá nova redação aos incisos I e VII do art. 208, de forma a prever a obrigatoriedade do ensino de quatro a dezessete anos e ampliar a abrangência dos programas suplementares para todas as etapas da educação básica, e dá nova redação ao $\S 4^{\circ}$ do art. 211 e ao $\S 3^{\circ}$ do art. 212 e ao caput do art. 214, com a inserção neste dispositivo de inciso VI. Diário Oficial da União, Brasília, DF, 12 nov. 2009. Seção 1, p. 8.

BRASIL. Lei $\mathrm{n}^{\circ}$ 11.274, de 6 de fevereiro de 2006. Altera a redação dos arts. 29, 30, 32 e 87 da Lei no 9.394, de 20 de dezembro de 1996, que estabelece as diretrizes e bases da educação nacional, dispondo sobre a duração de 9 (nove) anos para o ensino fundamental, com matrícula obrigatória a partir dos 6 (seis) anos de idade. Diário Oficial da União, Brasília, DF, 7 fev. 2006. Seção 1, p. 1. 
BRASIL. Instituto Nacional de Estudos e Pesquisas Educacionais Anísio Teixeira (Inep). Relatório do $2^{\circ}$ Ciclo de Monitoramento das Metas do Plano Nacional de Educação - 2018. Brasília, 2018.

FERRARI, A. R. Analfabetismo no Brasil: tendência secular e avanços recentes: resultados preliminares. Cadernos de Pesquisa, São Paulo, n. 52, p. 35-49, fev. 1985.

FERRARI, A. R. Escola e produção do analfabetismo no Brasil. Educação \& Realidade, Porto Alegre, v. 12, n. 2, p. 81-95, jul./dez. 1987.

FERRARO, A. R. Crianças e adolescentes no Rio Grande do Sul: trabalho e analfabetismo. Educação \& Realidade, Porto Alegre, v. 22, n. 2, p. 204-221, jul./dez. 1997.

FERRARO, A. R. Diagnóstico da escolarização no Brasil. Revista Brasileira de Educação, Rio de Janeiro, n. 12, p. 22-47, set./dez. 1999.

FERRARO, A. R. Diagnósticos da escolarização básica: um confronto de perspectivas. Ensaio: Avaliação e Políticas Públicas em Educação, Rio de Janeiro, v. 26, n. 99, p. 316-346, abr./jun. 2018.

FERRARO, A. R.; MACHADO, N. C. F. Da universalização do acesso à escola no Brasil. Educação \& Sociedade, Campinas, v. 23, n. 79, p. 213-241, ago. 2002.

FERRARO, A. R.; OLIVEIRA, A. D. R.; RIBEIRO, M. O “paradigma” da exclusão: discussão conceptual e pesquisa em educação. Cadernos de Educação, Pelotas, n. 13, p. 131-145, ago./dez. 1999.

FERRARO, A. R.; ROSS, S. D. Diagnóstico da escolarização no Brasil na perspectiva da exclusão escolar. Revista Brasileira de Educação, Rio de Janeiro, v. 22, n. 71, p. 1-26, 2017.

FLETCHER, P. R. A repetência no ensino de $1^{\circ}$ grau: um problema negligenciado da educação brasileira: uma análise preliminar e sugestão de avaliação adicional. Revista Brasileira de Administração Escolar, Porto Alegre, v. 3, n. 2, p. 10-41, jan./jun. 1985.

FLETCHER, P. R.; CASTRO, C. M. Os mitos, as estratégias e as prioridades para o ensino de $1^{\mathrm{o}}$ grau. Educação \& Realidade, Porto Alegre, v. 11, n. 1, p. 35-42, jan./jun. 1986.

INSTITUTO BRASILEIRO DE GEOGRAFIA E ESTATÍSTICA (IBGE). Pesquisa Nacional por Amostra de Domicílios (Pnad): microdados. Disponível em: < https:// 
ww2.ibge.gov.br/home/estatistica/populacao/trabalhoerendimento/pnad2015/ microdados.shtm >. Acesso em: 9 maio 2019.

INSTITUTO BRASILEIRO DE GEOGRAFIA E ESTATÍSTICA (IBGE). Pesquisa Nacional por Amostra de Domicílios (Pnad Contínua): microdados 2012-2017.

Disponível em: <https://www.ibge.gov.br/estatisticas/sociais/trabalho/9173-pesquisanacional-por-amostra-de-domicilios-continua-trimestral.html $?=\& \mathrm{t}=$ microdados $>$. Acesso em: 9 maio 2019.

LEWIN, K. M. Improving access, equity and transitions in education: creating a reserach agenda. Brighton: University of Susex, 2007.

LEWIN, K. M. Taking targets to task revisited: how indicators of progress on access to education can mislead. Brighton: University of Sussex, 2011.

LEWIN, K. M.; SABATES, R. Who gets what? Is improved access to basic education pro-poor in Sub-Saharan Africa? International Journal of Educational Development, v. 32, n. 4, p. 517-528, jul. 2012.

RIBEIRO, S. C. A pedagogia da repetência. Estudos Avançados, São Paulo, v. 12, n. 5, p. 7-21, maio/ago. 1991.

SIMÕES, A. A. As metas de universalização da educação básica no Plano Nacional de Educação: o desafio do acesso e a evasão dos jovens de famílias de baixa renda no Brasil. Brasília: Inep, 2016. (PNE em Movimento, 4).

TEIXEIRA, A. S. Nota preliminar. Revista Brasileira de Estudos Pedagógicos, v. 22, n. 56, p. 53-55, out./dez. 1954. 



\section{APÊNDICE}

\section{APÊNDICE A - GRÁFICOS SUPLEMENTARES}

0

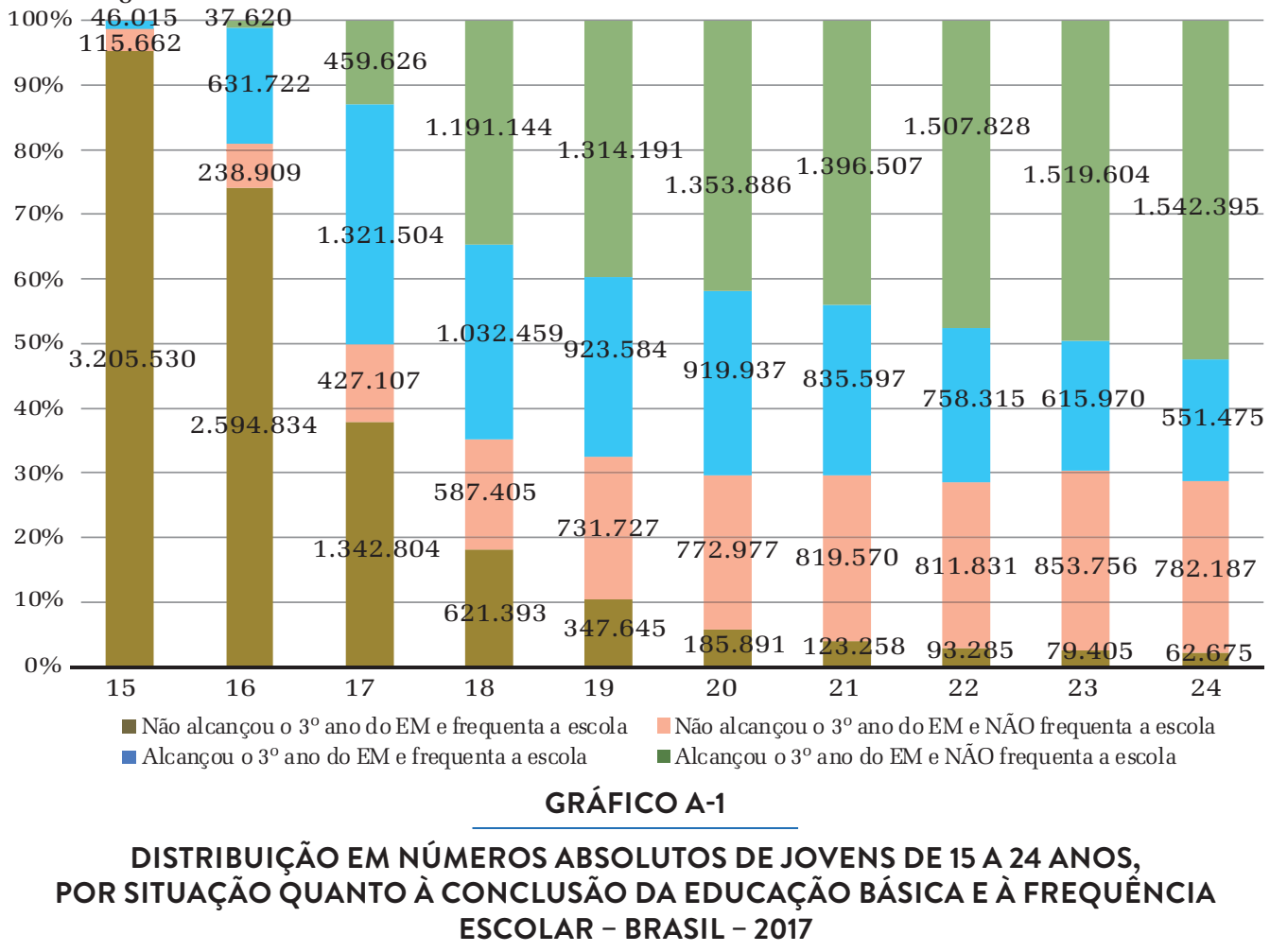

Fonte: Elaboração própria com base em dados de Pnad Contínua / IBGE (2017). 


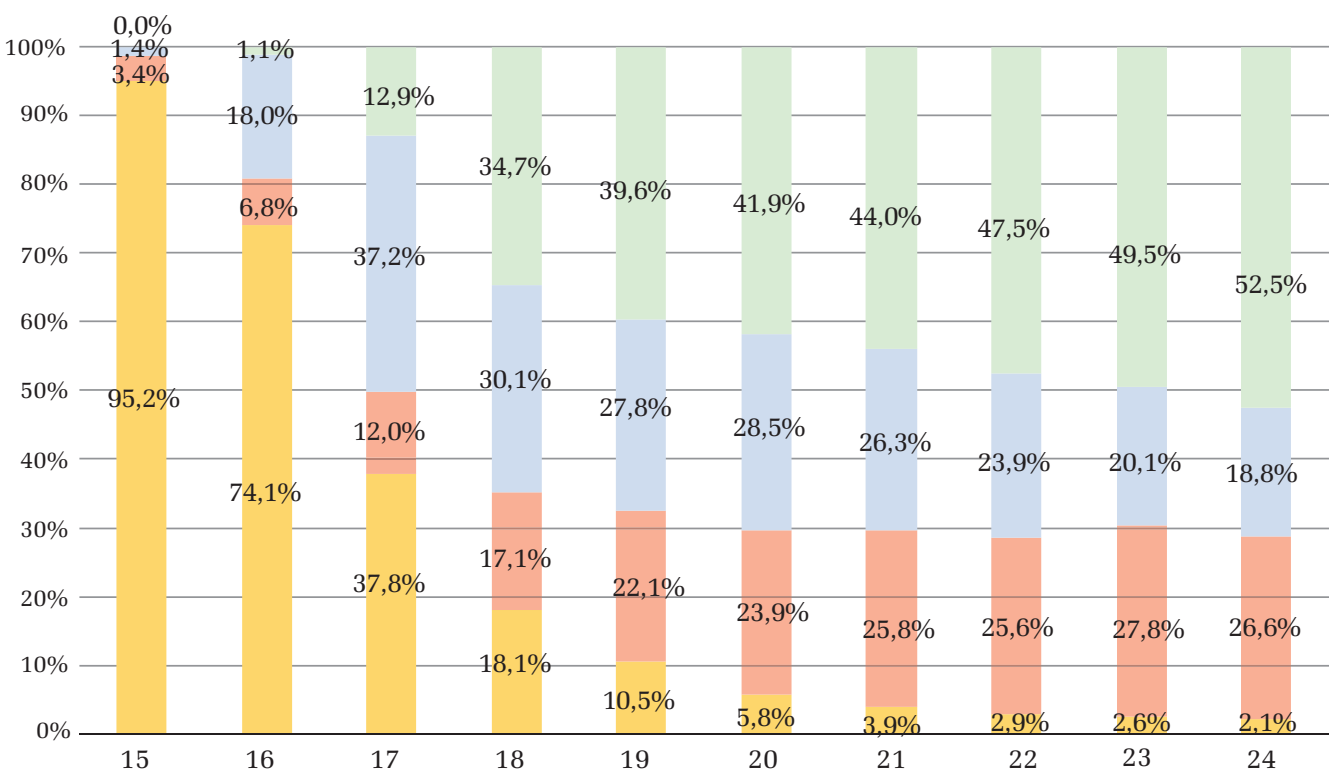

Não alcançou o $3^{\circ}$ ano do EM e frequenta a escola Não alcançou o $3^{\circ}$ ano do EM e NÃO frequenta a escola Alcançou o $3^{\circ}$ ano do EM e frequenta a escola

Alcançou o $3^{\circ}$ ano do EM e NÃO frequenta a escola

GRÁFICO A-2

\section{DISTRIBUIÇÃO PERCENTUAL DE JOVENS DE 15 A 24 ANOS POR SITUAÇÃO QUANTO À} CONCLUSÃO DA EDUCAÇÃO BÁSICA E À FREQUÊNCIA ESCOLAR - BRASIL - 2017

Fonte: Elaboração própria com base em dados de Pnad Contínua / IBGE (2017).

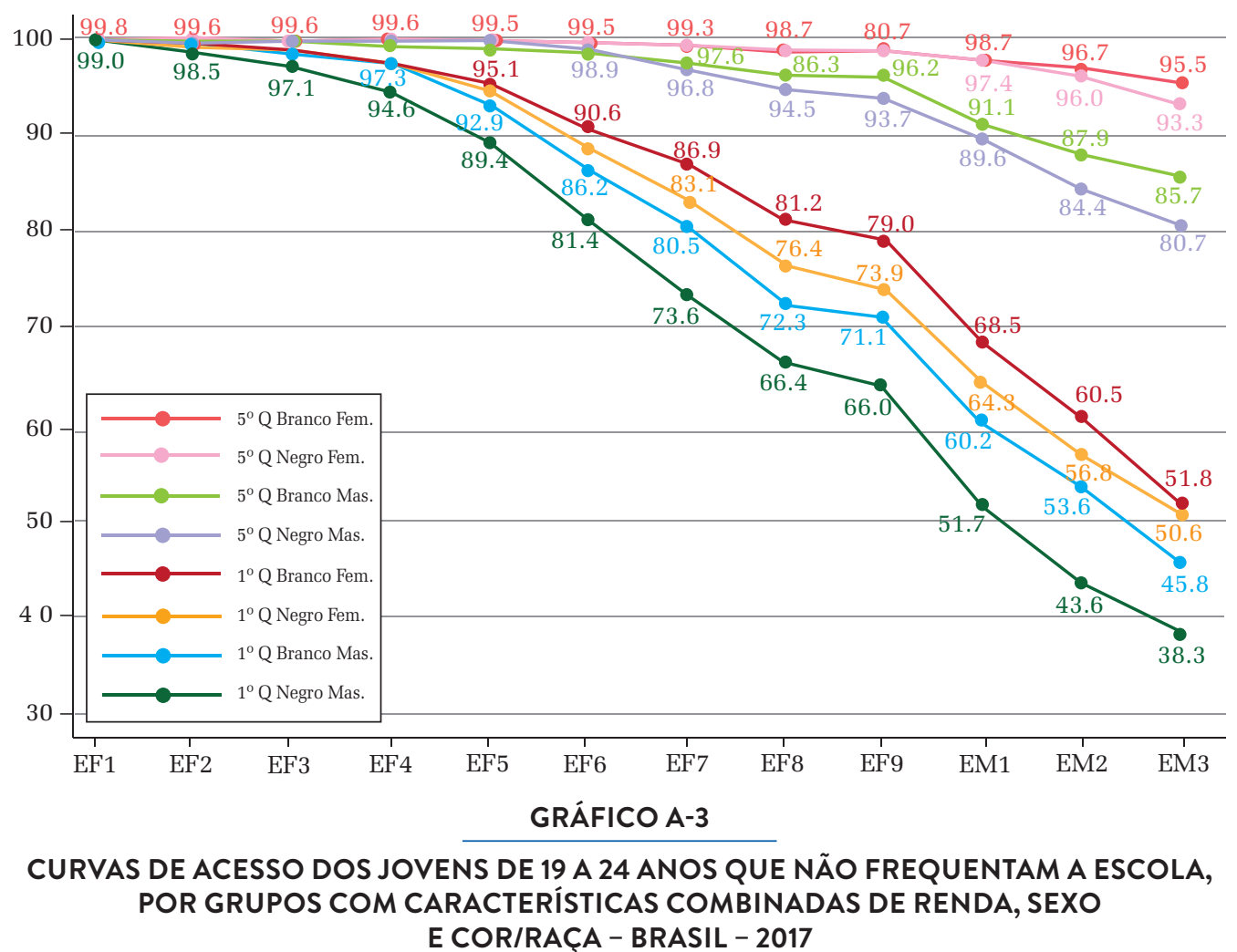

Fonte: Elaboração própria com base em dados de Pnad Contínua / IBGE (2017). 


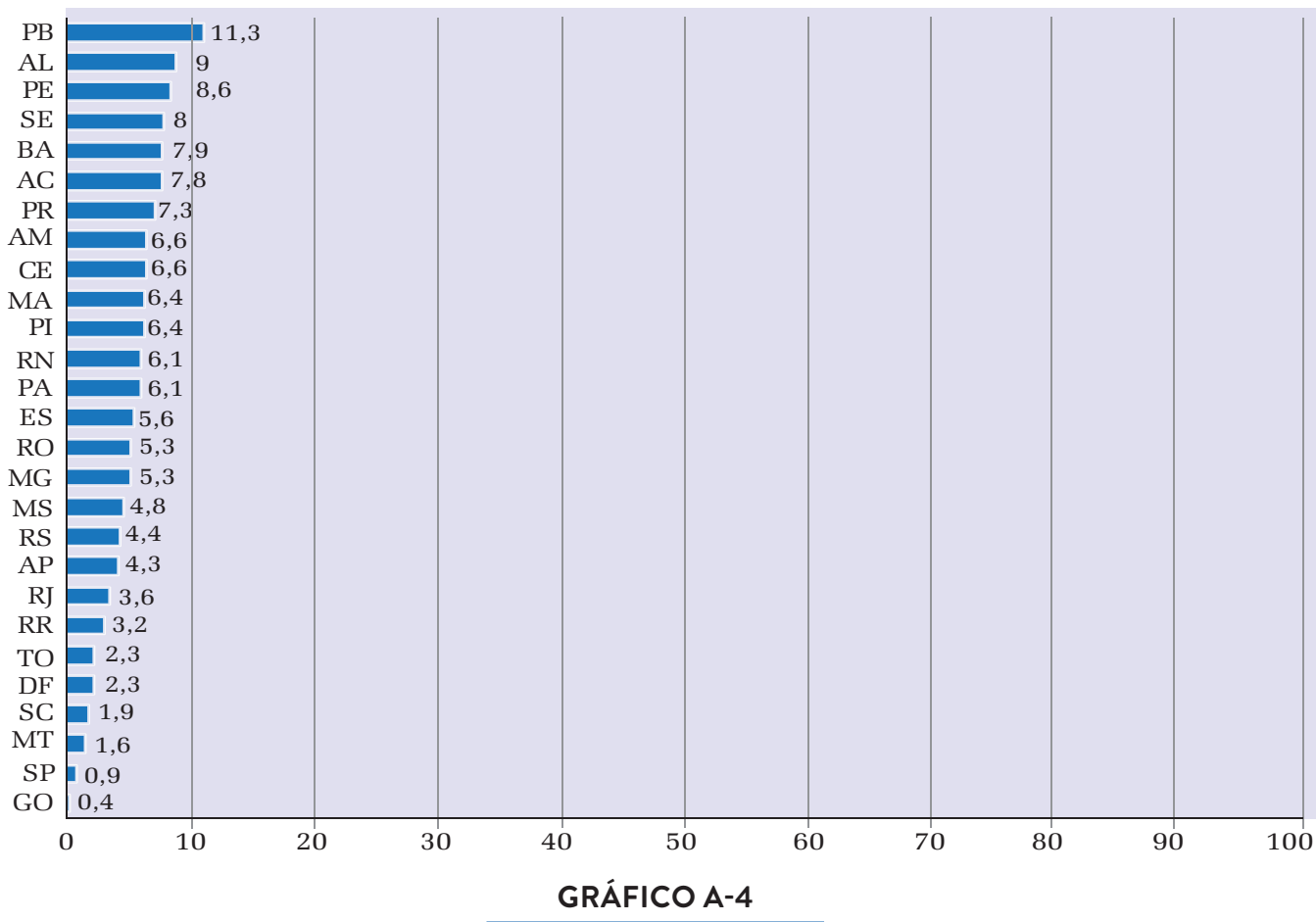

DIFERENÇA (P.P.) ENTRE O $5^{\circ} \mathrm{Q}$ E $O 1^{\circ} \mathrm{Q}$ NO PERCENTUAL DE ACESSO DOS JOVENS DE 19 A 24 ANOS AO $5^{\circ}$ ANO DO ENSINO FUNDAMENTAL, POR ESTADO - BRASIL - 2017

Fonte: Elaboração própria com base em dados de Pnad Contínua / IBGE (2017).

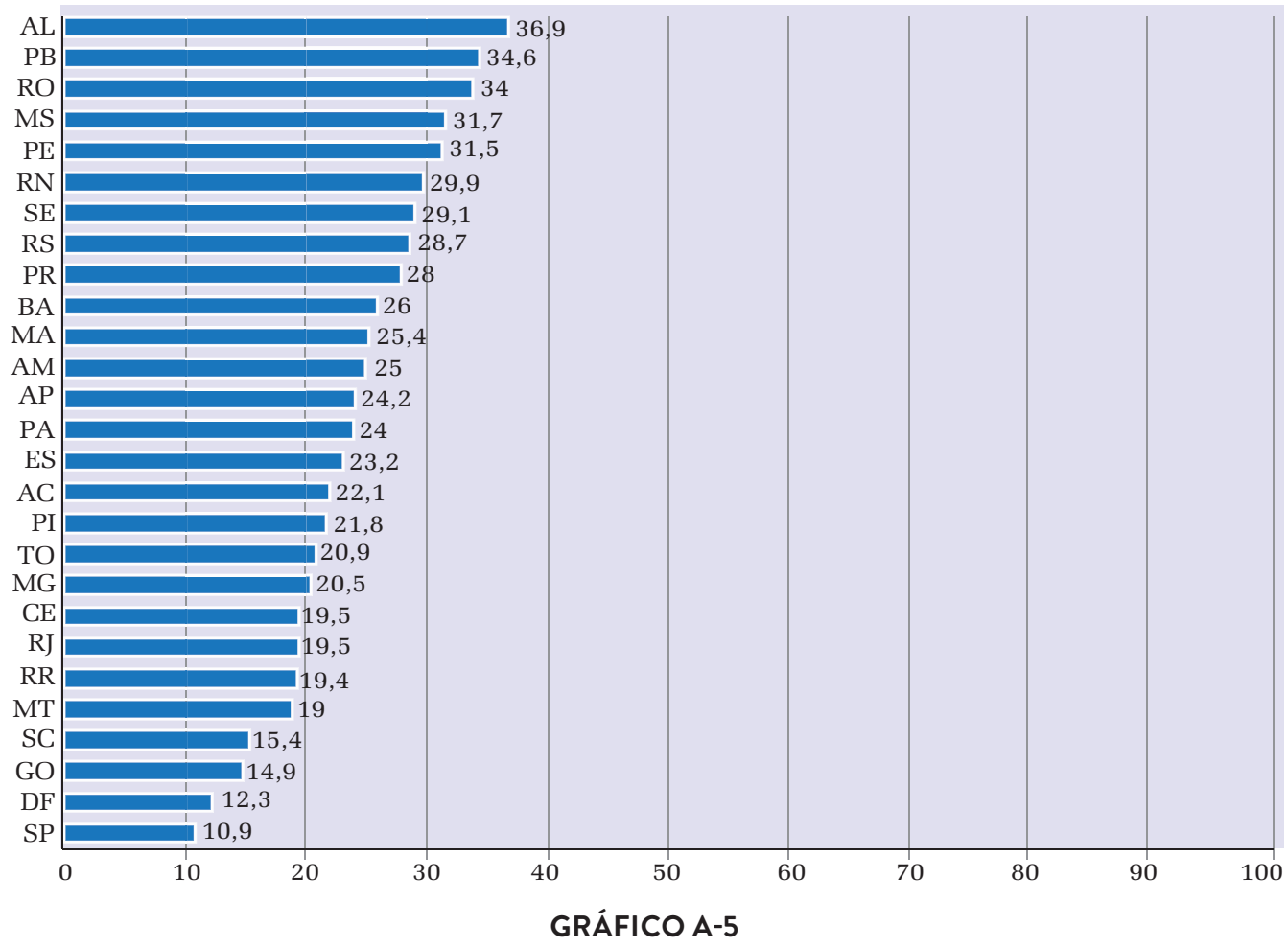

DIFERENCAA (P.P.) ENTRE O $5^{\circ} \mathrm{Q}$ E $O 1^{\circ} \mathrm{Q}$ NO PERCENTUAL DE ACESSO DOS JOVENS DE 19 A 24 ANOS AO $9^{\circ}$ ANO DO ENSINO FUNDAMENTAL, POR ESTADO - BRASIL - 2017

Fonte: Elaboração própria com base em dados de Pnad Contínua / IBGE (2017). 


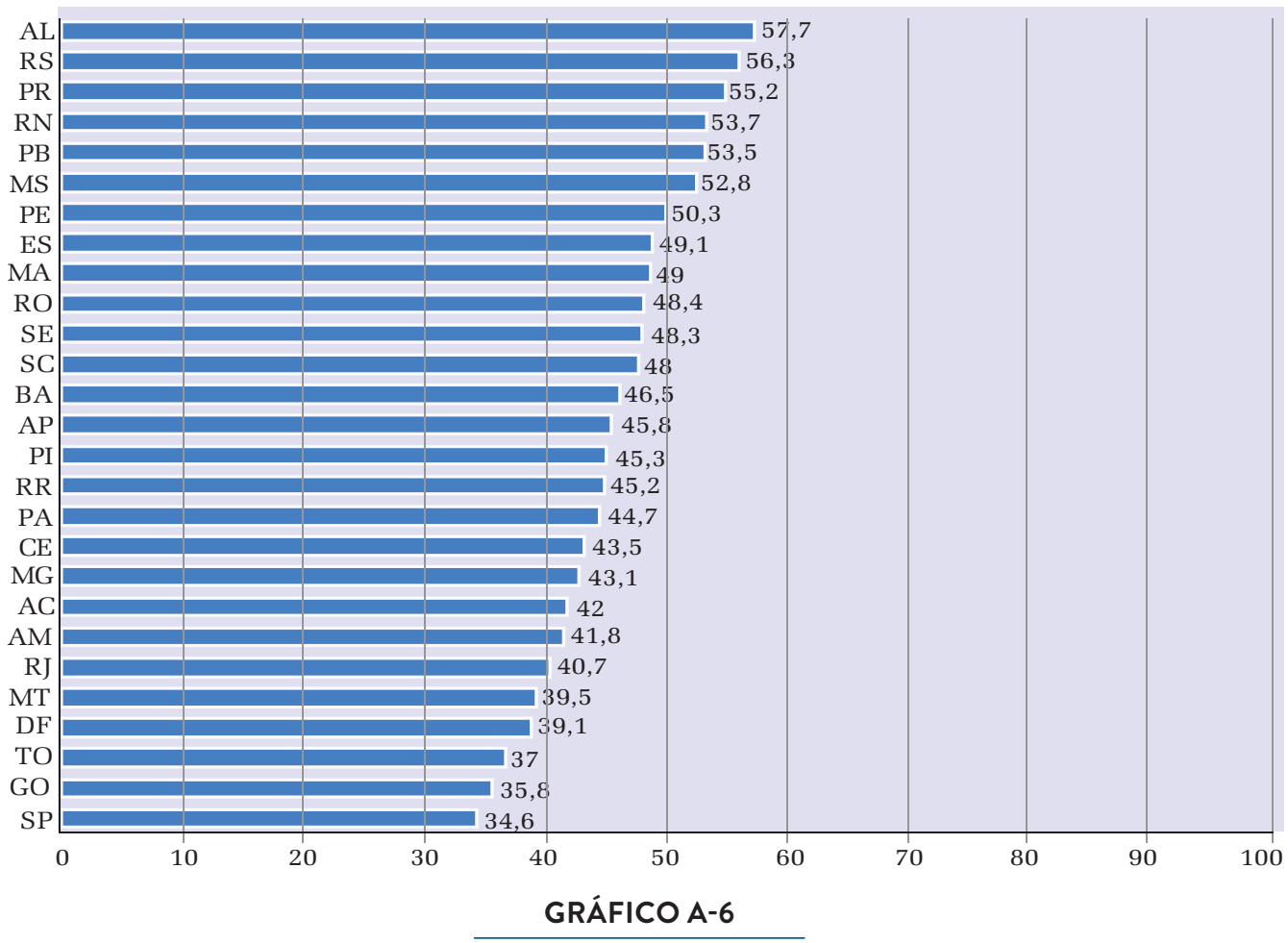

DIFERENÇA (P.P.) ENTRE O $5^{\circ} \mathrm{Q}$ E O $1^{\circ} \mathrm{Q}$ NO PERCENTUAL DE ACESSO DOS JOVENS DE 19 A 24 ANOS AO $3^{\circ}$ ANO DO ENSINO MÉDIO, POR ESTADO - BRASIL - 2017

Fonte: Elaboração própria com base em dados de Pnad Contínua / IBGE (2017).

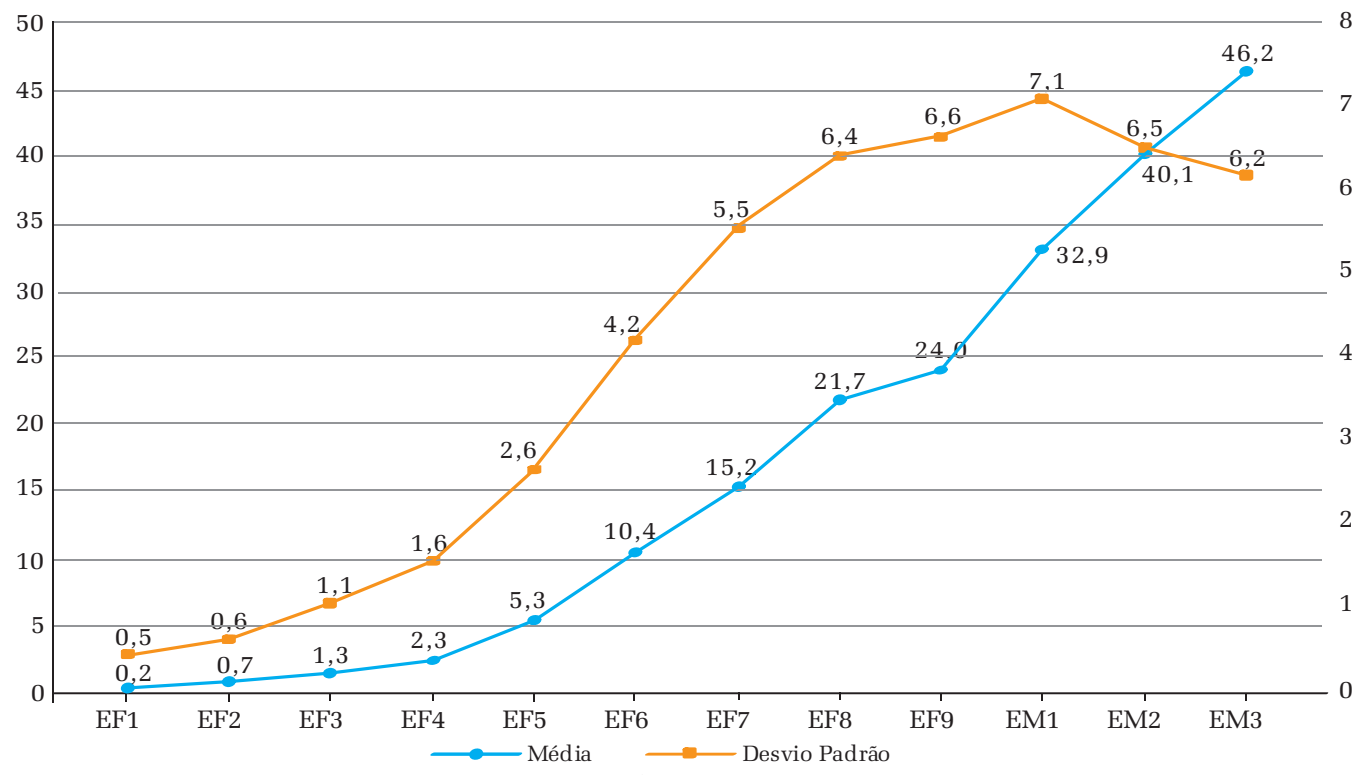

GRÁFICO A-7

VALOR MÉDIO E DESVIO PADRÃO DA DESIGUALDADE DE ACESSO AOS ANOS ESCOLARES ENTRE OS JOVENS DE 19 A 24 ANOS DOS 20\% MAIS POBRES E 20\% MAIS RICOS PARA O CONJUNTO DOS ESTADOS - BRASIL - 2017

Fonte: Elaborado pelo autor com base nos microdados da Pnad contínua / IBGE (2017). 